\title{
Social conditions in the Kurdish narrative
}

\author{
Salim Rashed Salih ${ }^{1}$
}

Abdullah Rahman Awlah ${ }^{2}$

Received: Feb 23, 2018 Reviewed: Mar 11, $2018 \quad$ Accepted: Mar 17, 2018

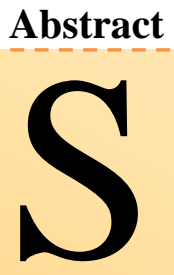

ocial space is an important part of community life. And have a significant impact on the lives of its members. Therefore, because the society guarantees in its own depth many social issues and events, while at the same time it is a link between social interaction and social interaction.These relationships and social connections are visually intertwined as a spider web, and because people are social, it is impossible to live alone, so they have a constant connection with individuals and the culture traditions of society. On the other hand, he faced many setbacks and problems, faced with social problems and affected his life and future.On this basis, the human being in his private life revolves around his social issues. No component can have such an effect. In the framework of literature in general and the novel in particular is the vast area of communication between the relations between literature and social issues in the community delay on the shoulders, and works in the way of this space and embrace these problems and social constraints and find solutions satisfactory and to indicate the future of the (new generation). And from this observatory we have worked in the examples of the next novel to present to the new generation. And we tried in several models of the Kurdish novel to show these social issues, and to clarify the impact of these social issues in the text of the narrators and show the opinion of the novel about these problems and obstacles. The factors that led us to choose this topic are to work more on the relationship of the novel to society. This research leads us to talk about the sociology of sociology as a branch of sociology of literature. In this subject in the Kurdish literary criticism, especially at the academic level, he worked on it only a few.

Keywords: Social condition, Kurdish narrative, Kurdish novel, Community

\section{Recommended citation:}

Salih R. S. \& Awlah R. A. (2018). Social conditions in the Kurdish narrative. International Journal of Kurdish Studies 4 (2), 386-415. doi: 10.21600/ijoks.454461

\footnotetext{
${ }^{1}$ Asst. Prof. Dr., Department of Kurdish Language, College of Education, University of Salahaddin Erbil, Kurdistan Region of Iraq, E-mail:salim_shwani@yahoo.com

${ }^{2}$ Teacher, Department of Kurdish Language, College of Education-Makhmur, University of Salahaddin Arbil,

Kurdistan Region of Iraq, Email: abdulla.awla@su.edu.krd
} 


\title{
بارودوّخى كَومَلَاكهرى
}

له يانتايى دموى روّماه كوردكا

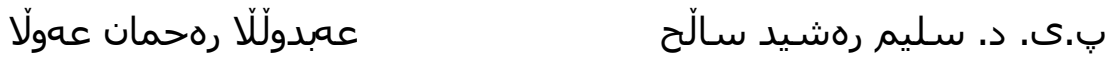

رِيْشَكى

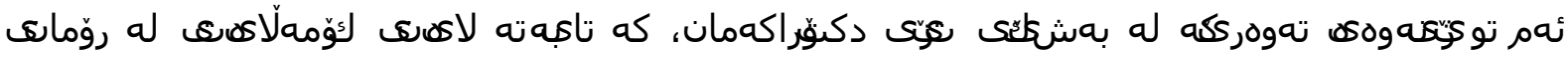

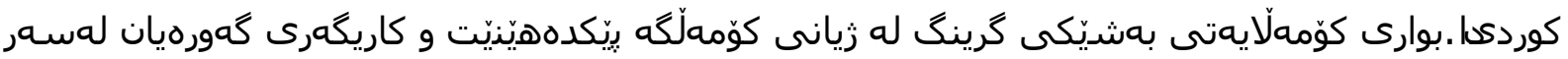

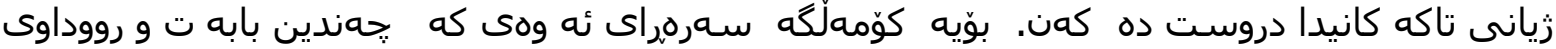

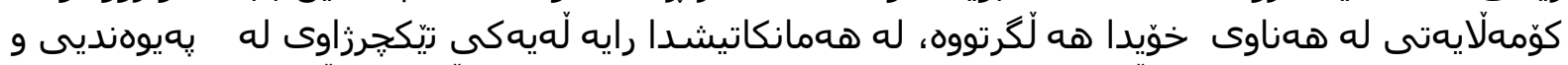

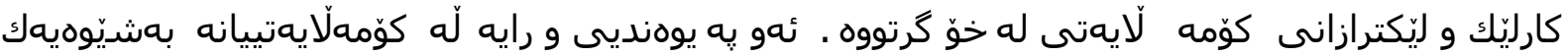

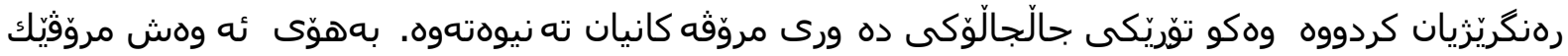

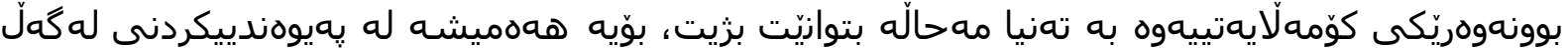

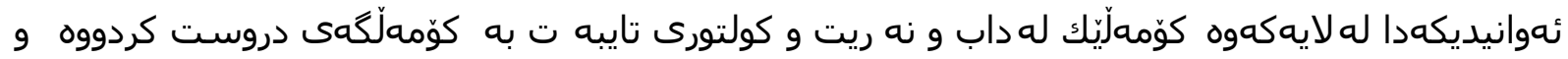

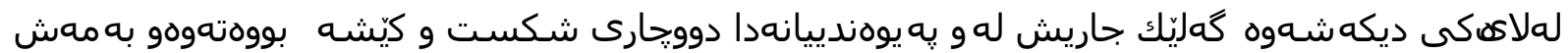

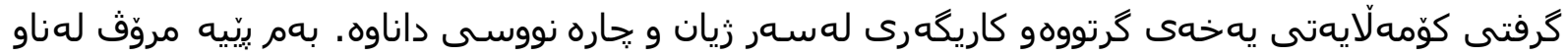

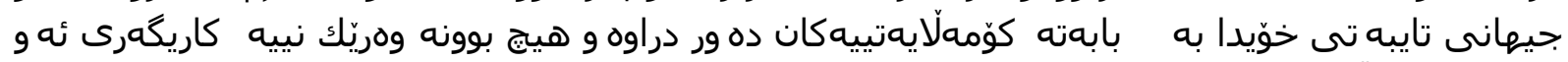

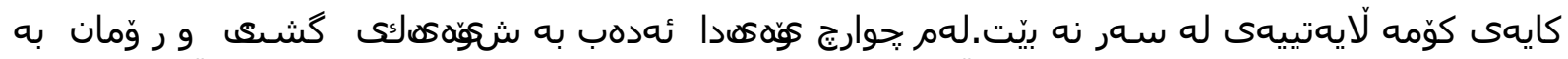

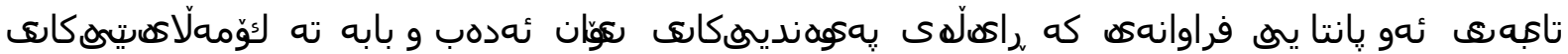

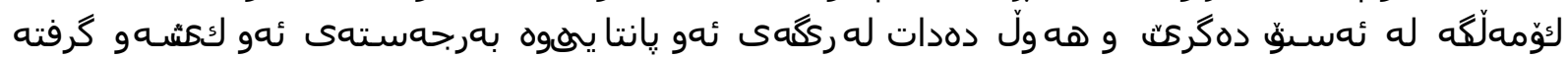

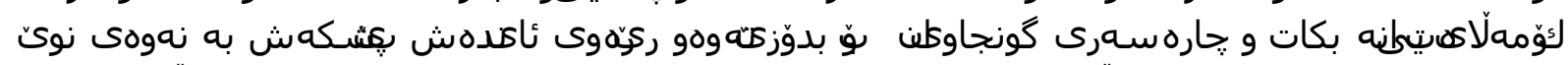

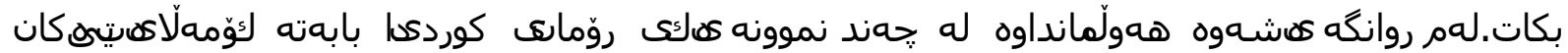

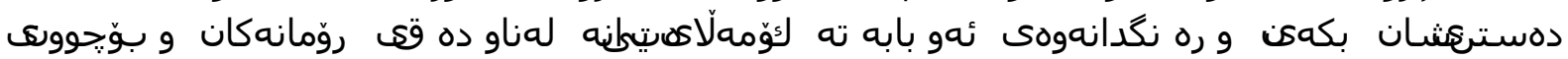

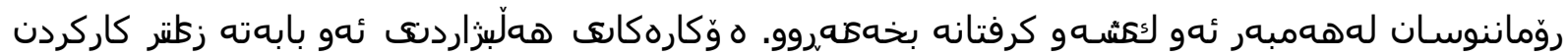

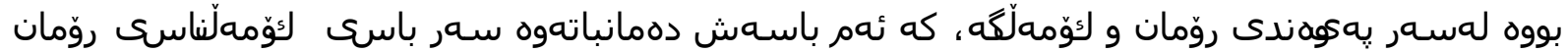

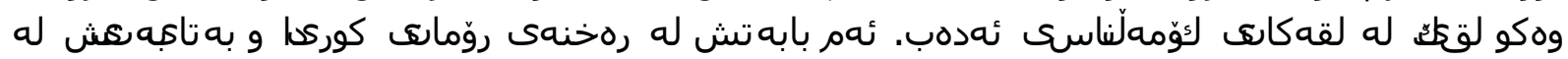

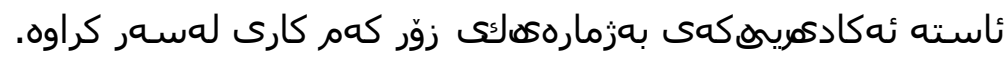

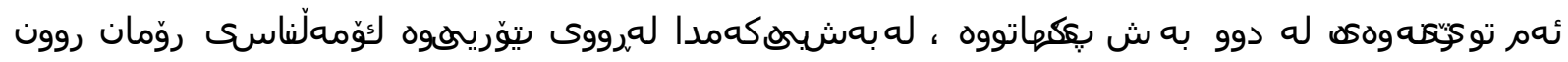

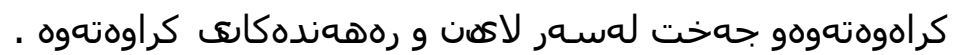

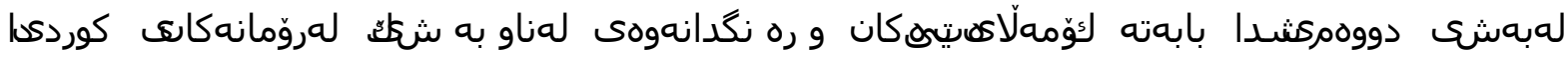

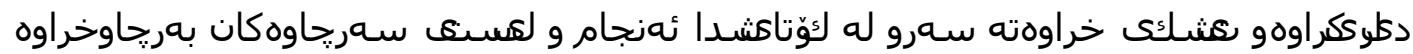

$$
\text { بaبs كaم }
$$

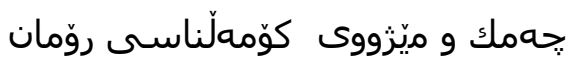

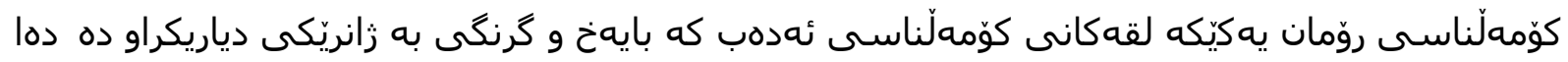

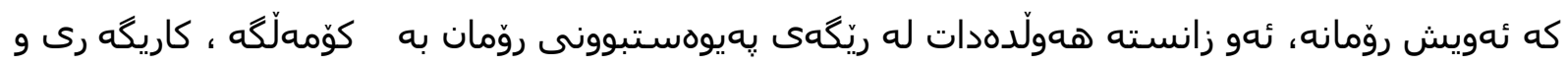

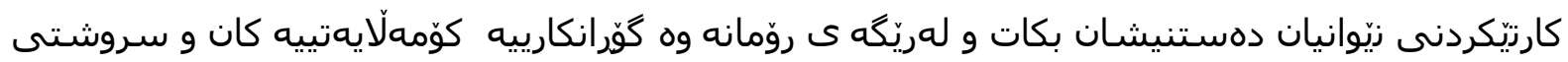


بهيوهندييه كوّمهلايهتييهكانى زيّوان مروّث و گروويه كوّملّايهتييهكان ديارى بكات و راده ى كارليّكردنيان

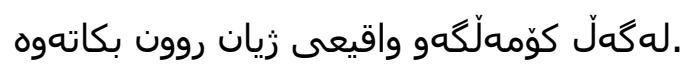

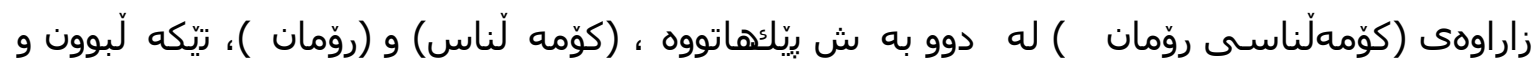

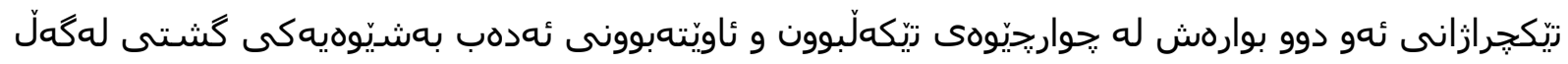

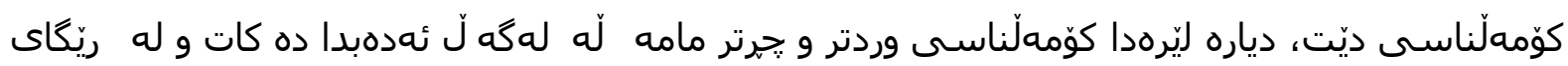

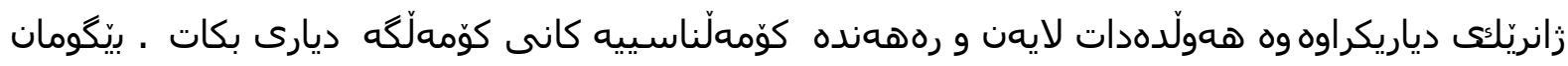

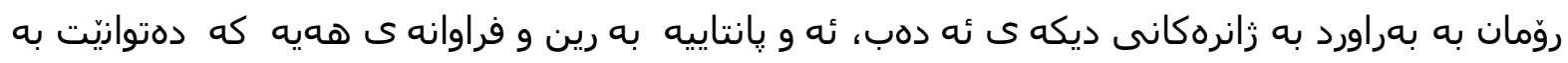

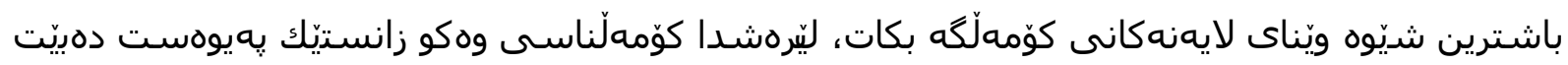

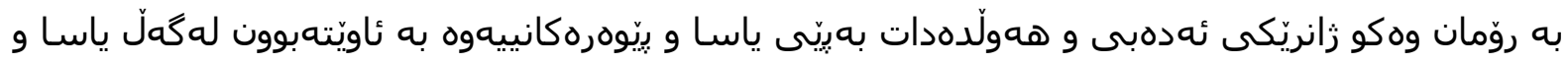

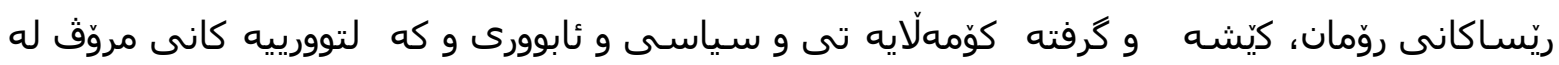

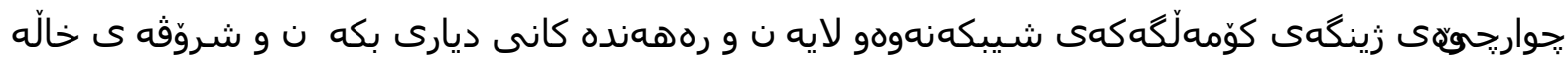

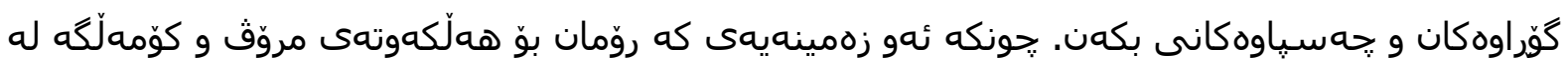

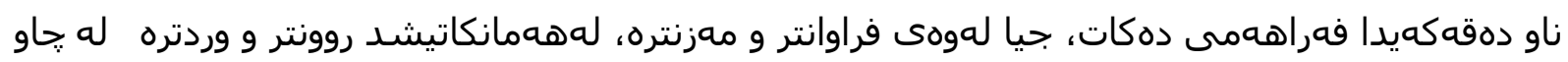

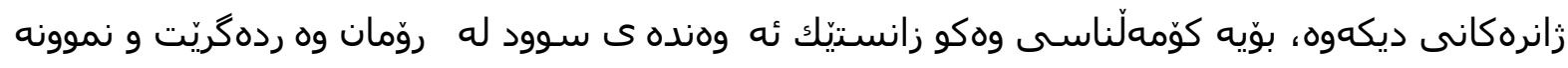

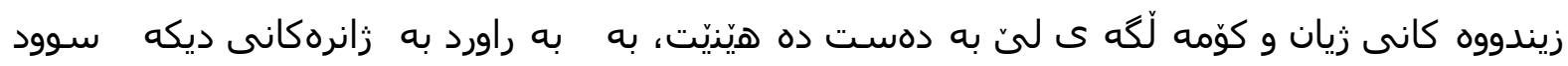

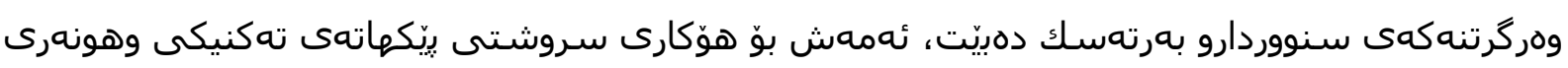

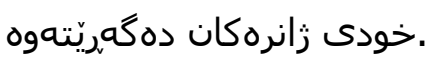

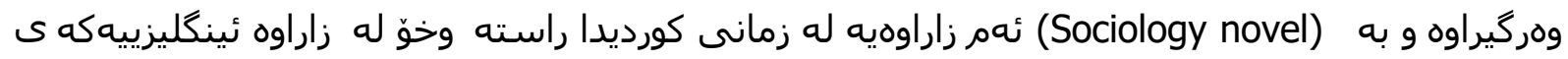

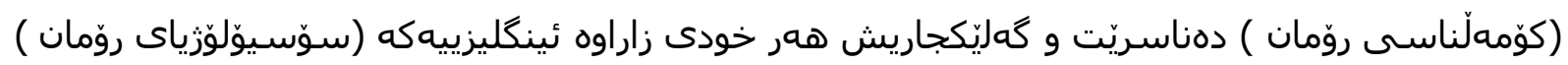

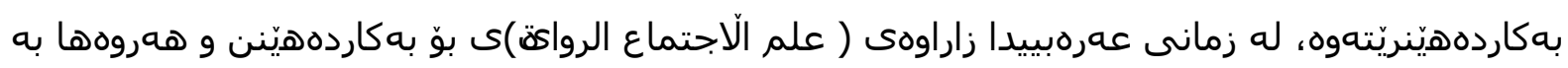

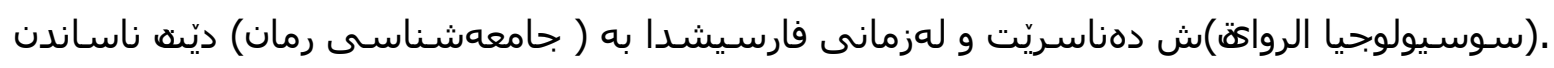

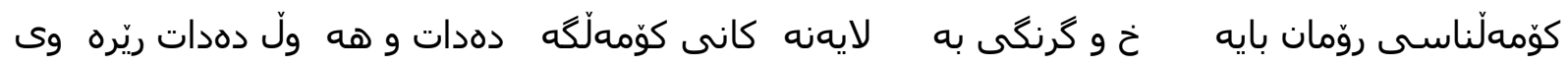

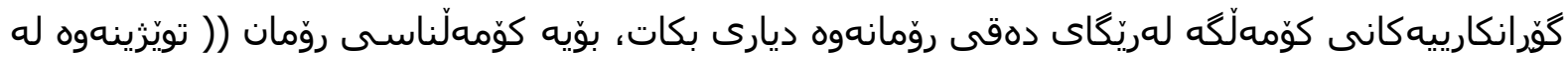

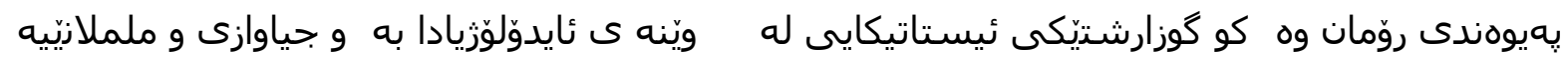

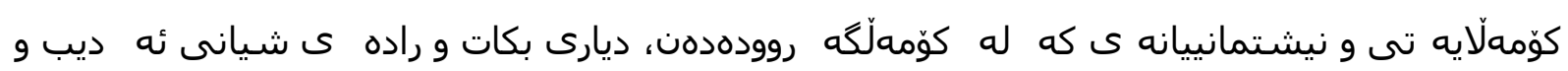

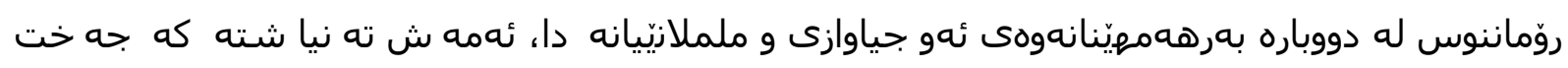

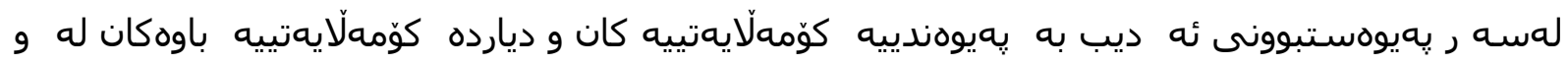

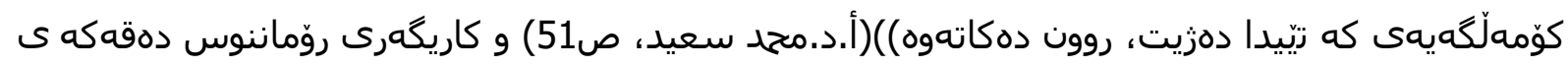

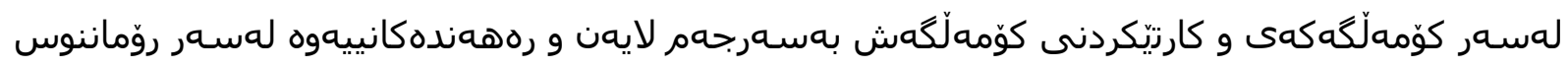

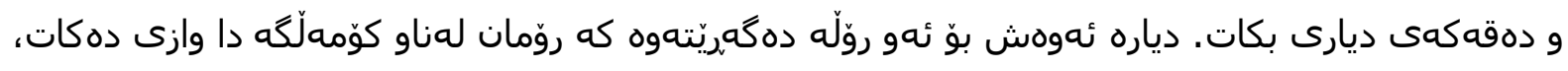

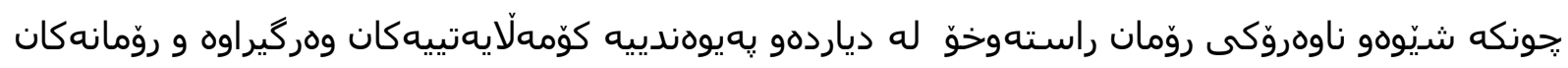

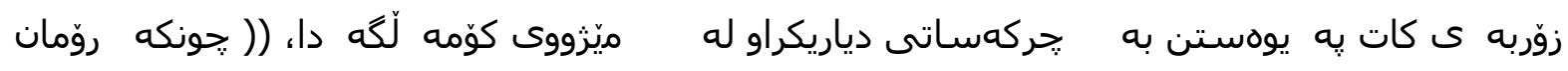

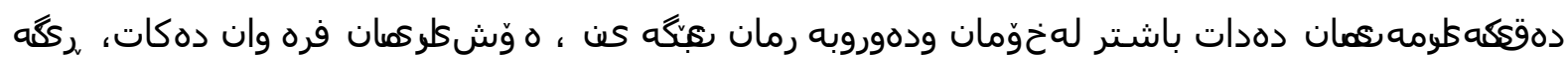

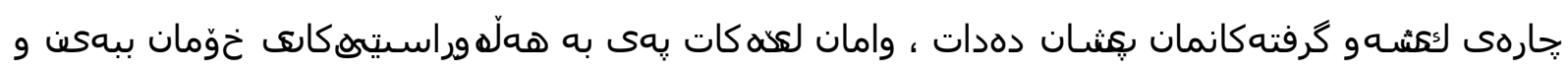

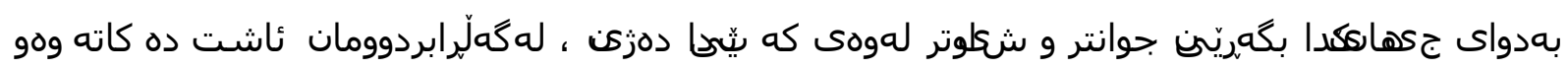


هانمان دهدات ربو له ئاسده كه كى كَ ش بكه كه وه )) ( ب.ى.د. نه جم ئه لّوهر، 2017، ل75)، له م

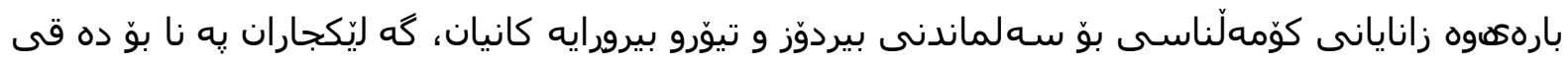

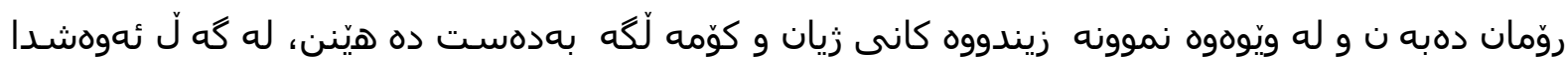

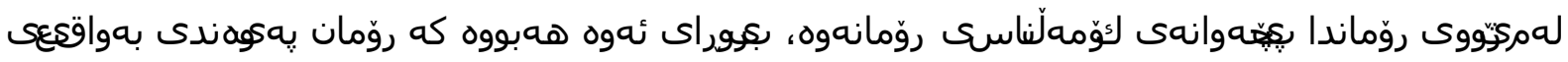

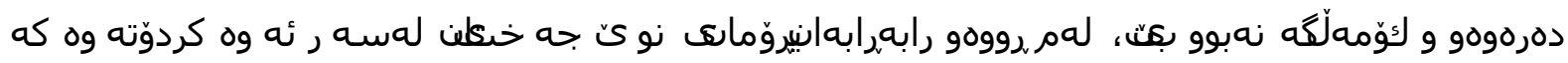

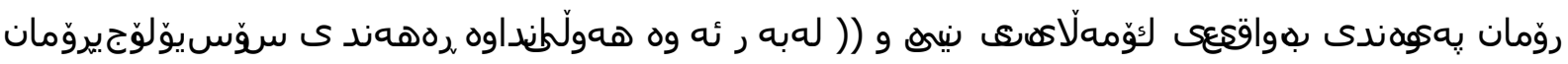

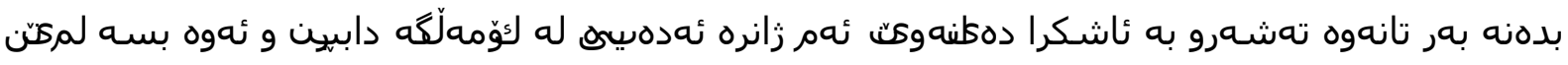

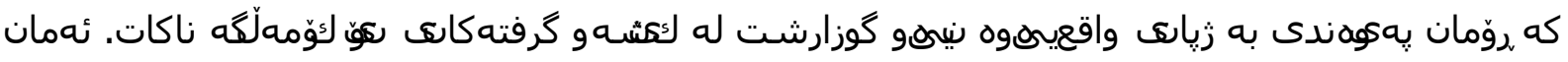

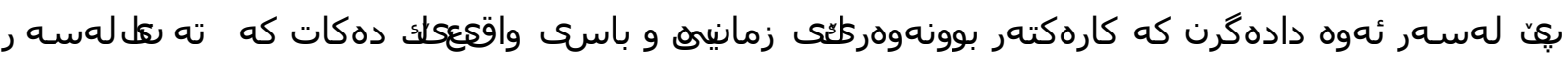

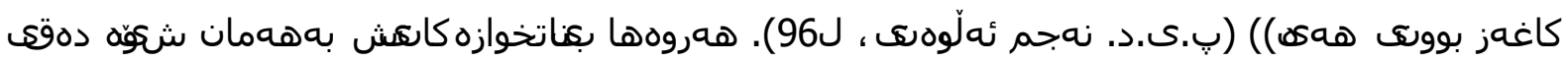

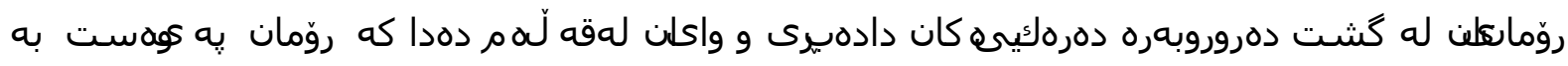

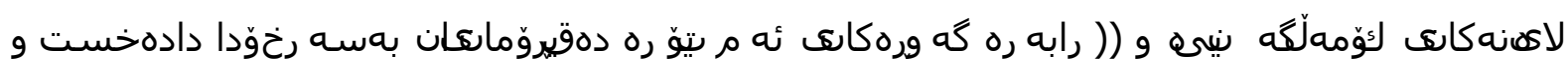

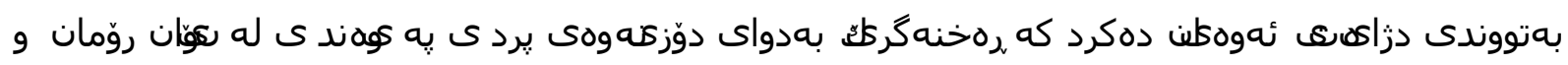

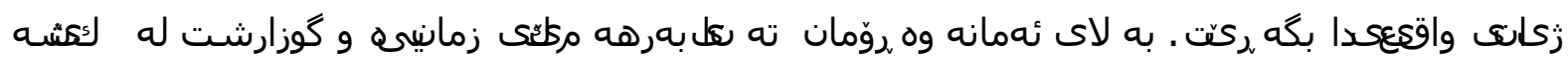

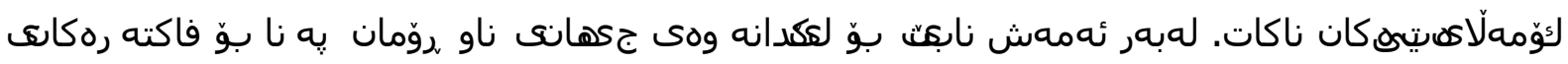

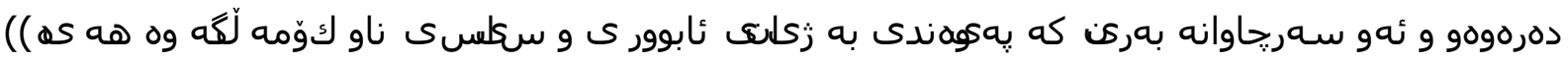

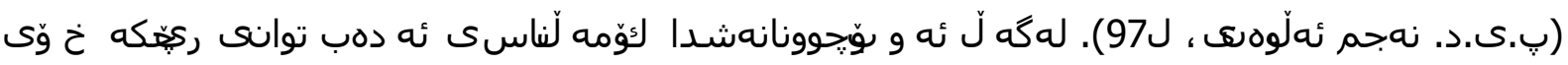

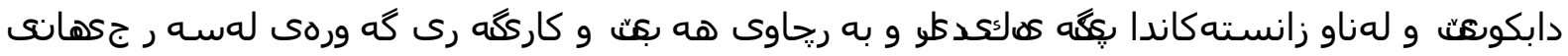

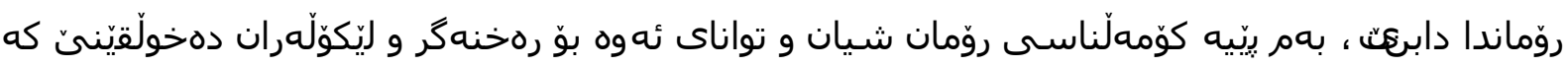

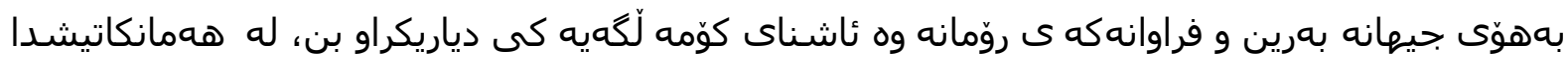

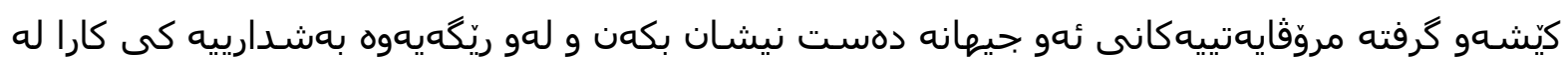

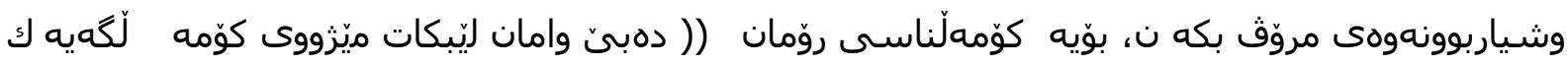

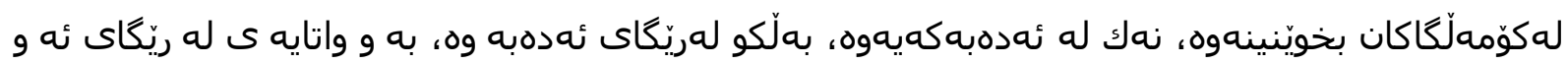

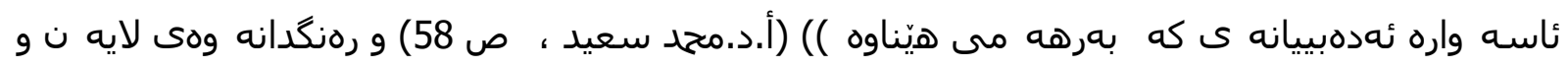

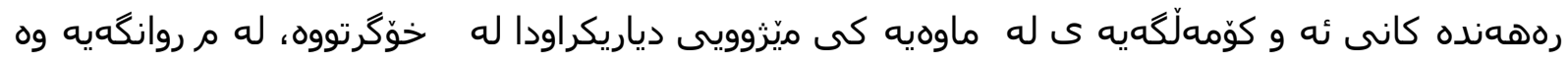

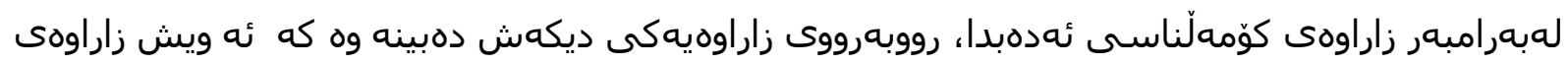

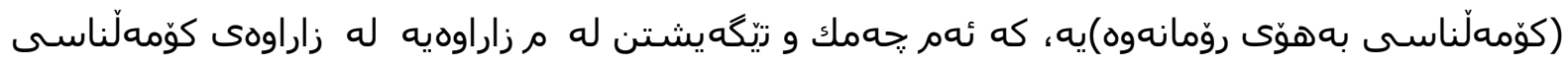

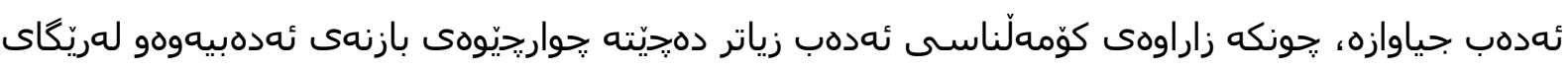

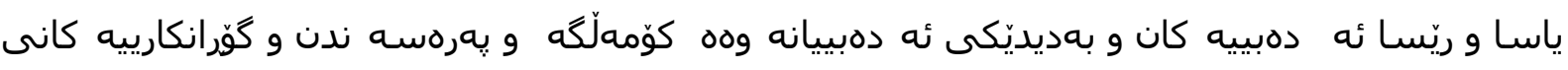

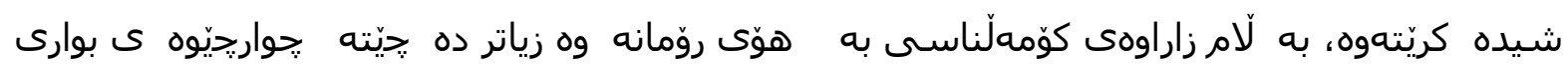

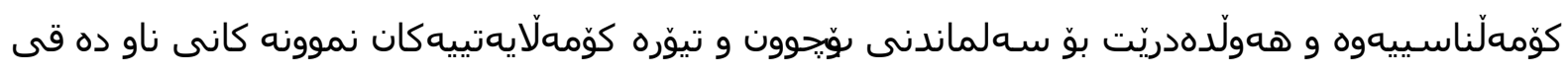

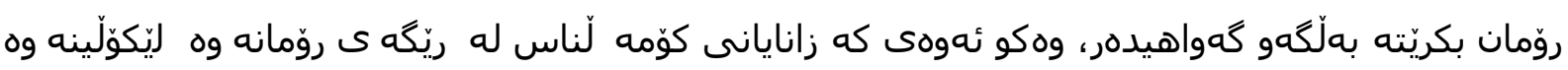

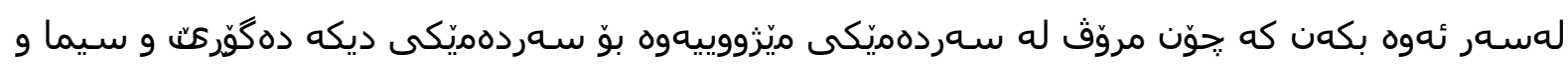

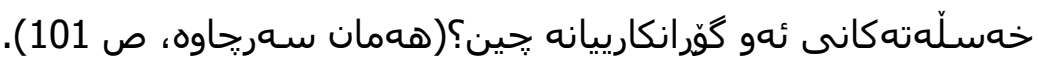




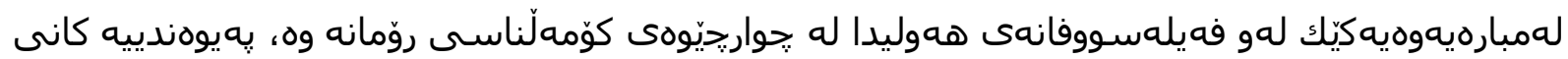

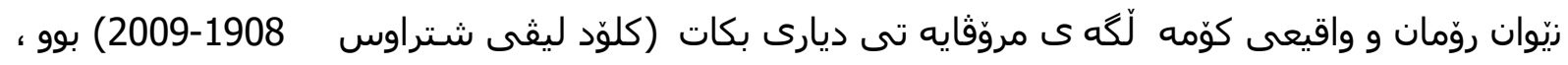

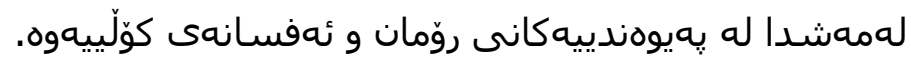

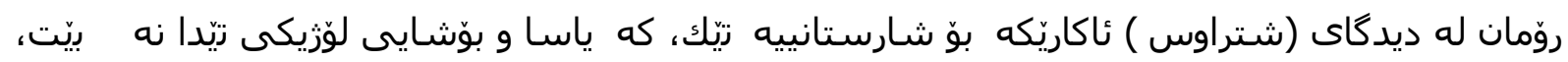

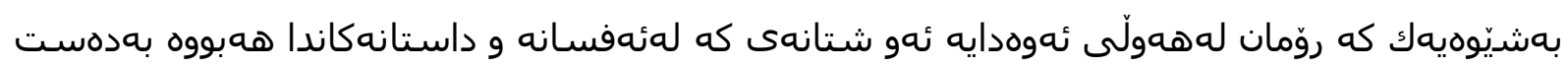

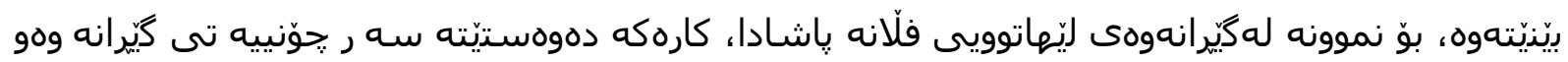

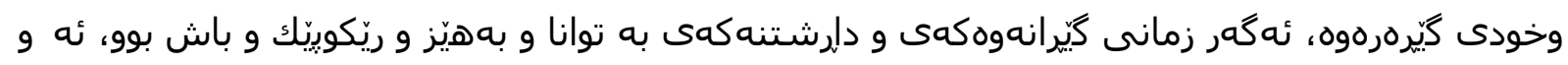

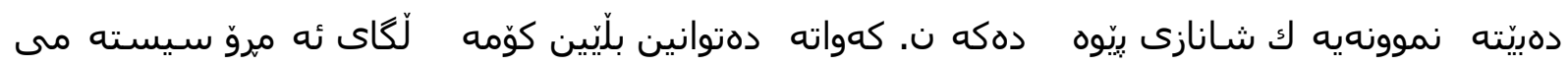

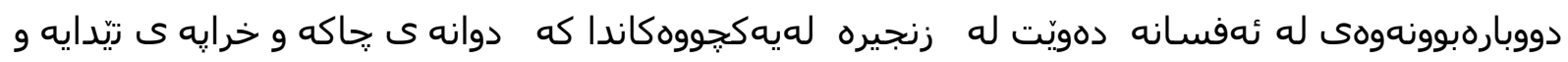

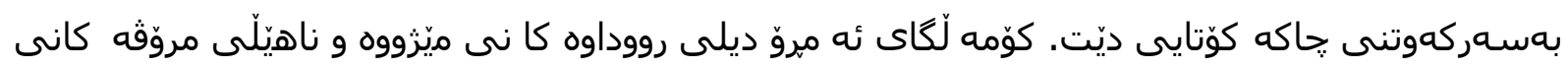

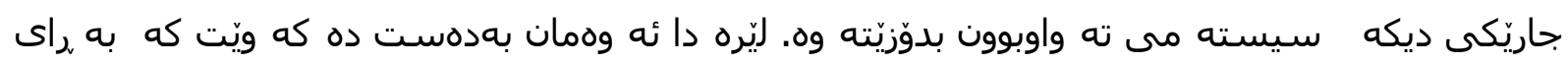

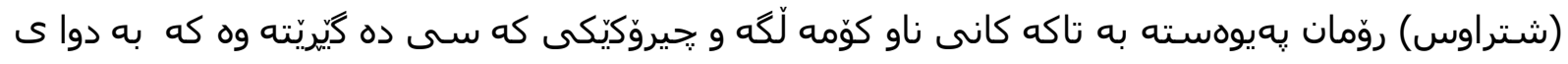

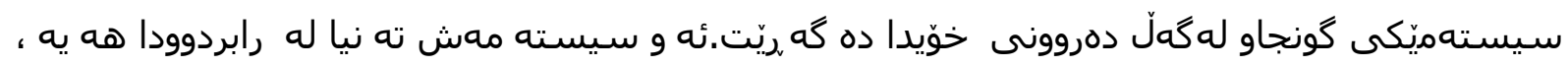

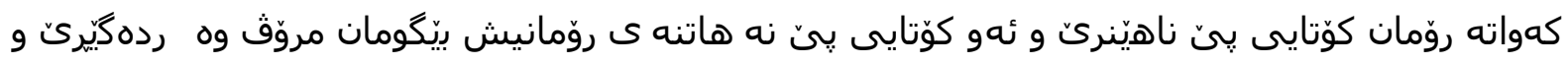

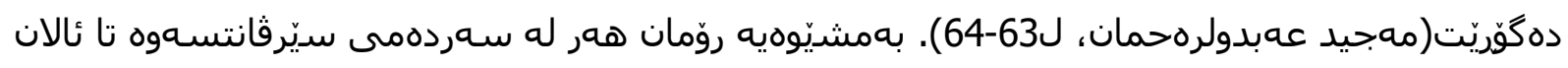

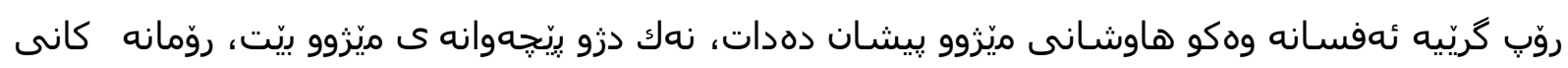

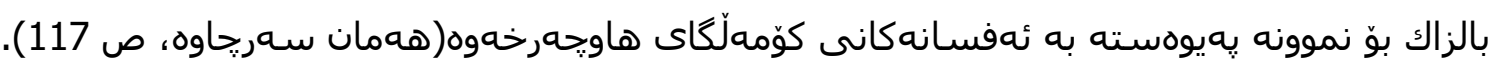

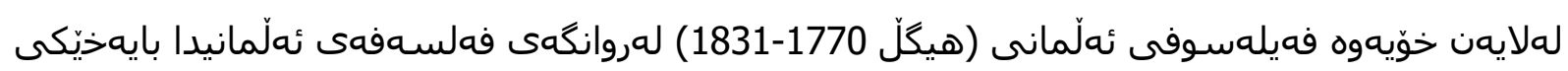
زوّرى به يهيوهندييه كانى زيّوان روّمان و شيعر و داستان داوه

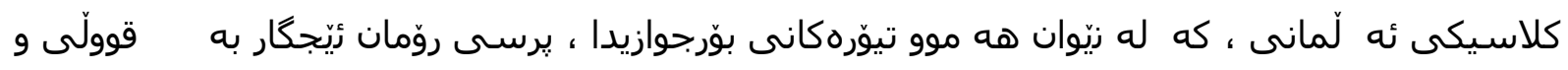

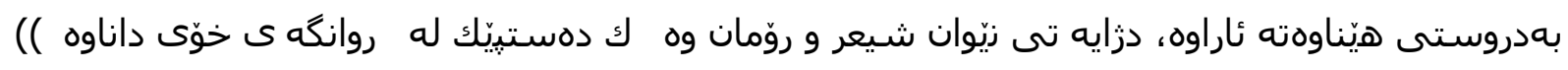

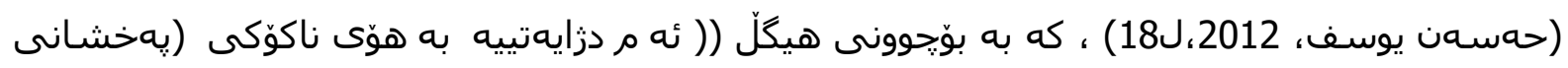

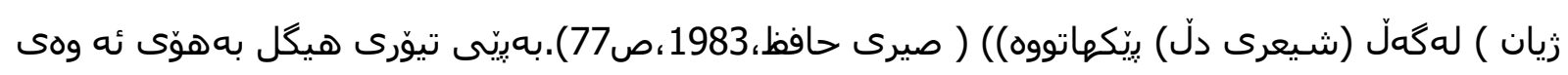

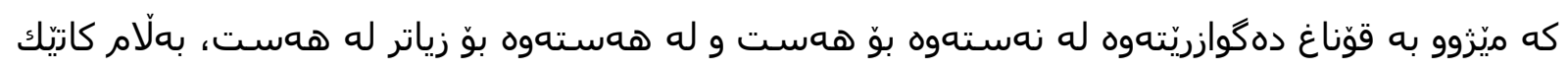

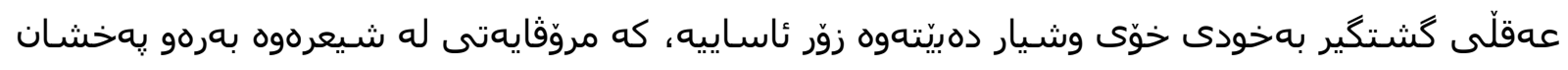

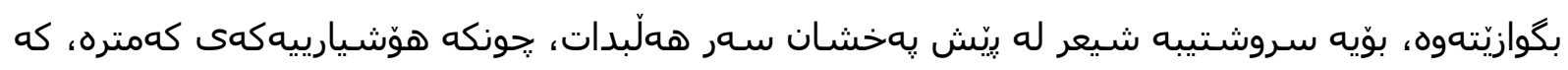

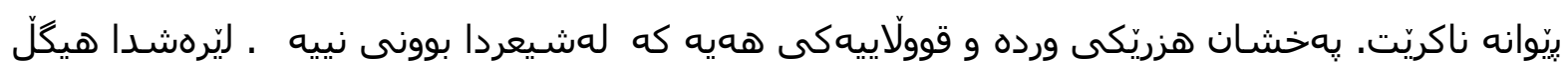

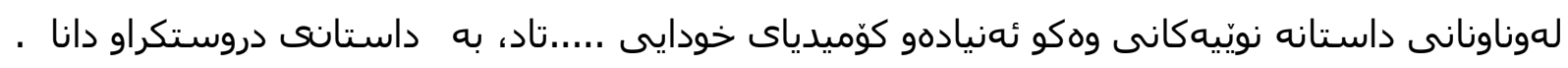

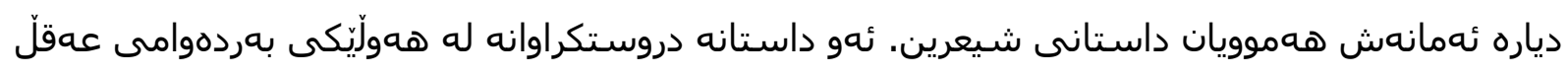

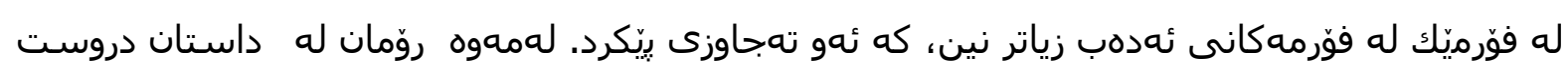

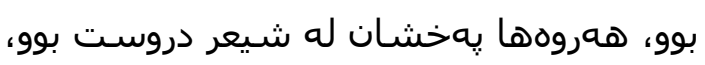

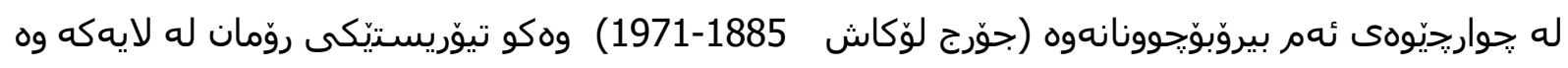

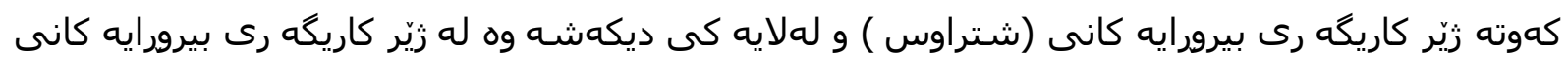

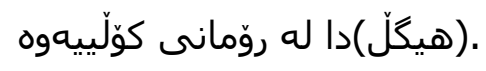




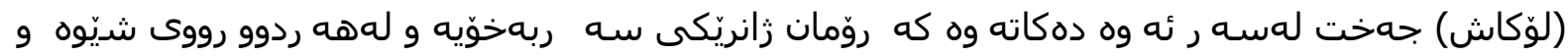
ناوهروّكوه له داستان جيا دهيّتهوه، ئهو جياكردنهوهيهش له دوو ئاستدا دهريّت، ئاستى يهكه مر بريتييه

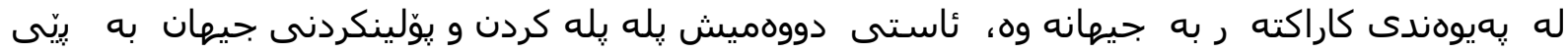

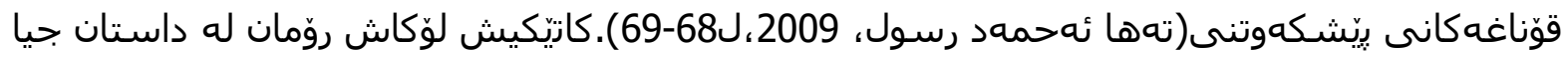

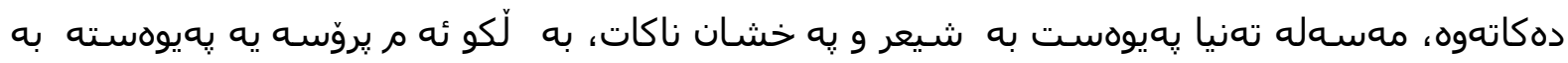

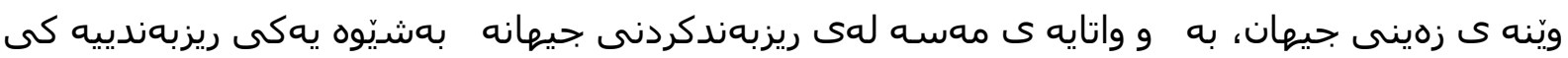

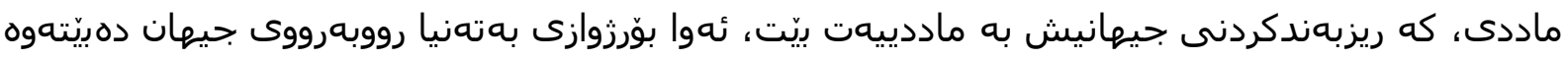

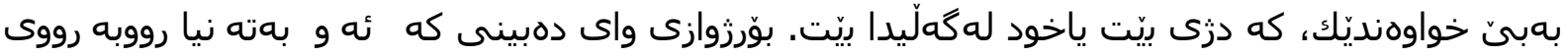

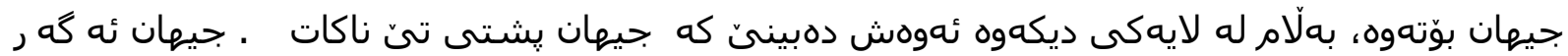

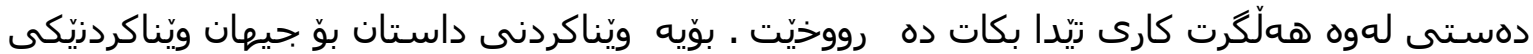
حه (حم)

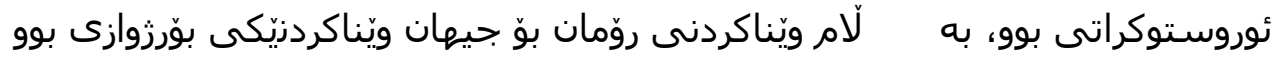

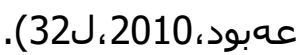

دياره دهبي دان بهو راستييهدا بذيّين كه تيوّرى روّمان، تيوّريّكى بهتهواوهتى ئهوروِيييه ، به و واتايه ى كه

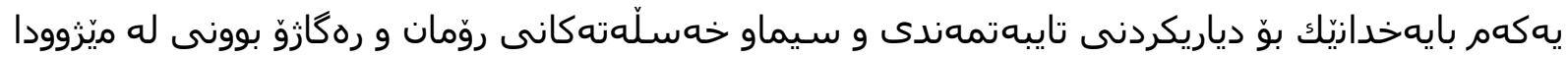

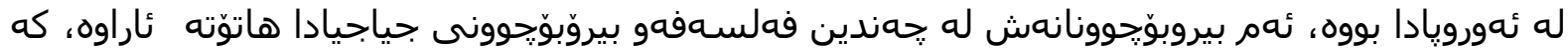

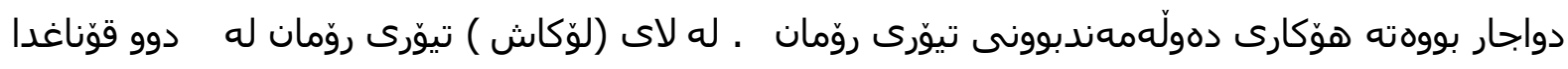

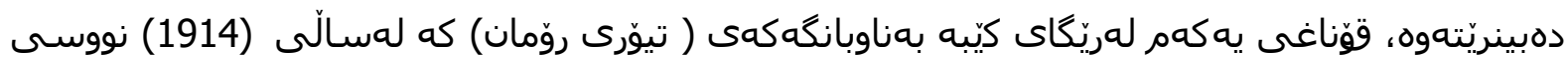

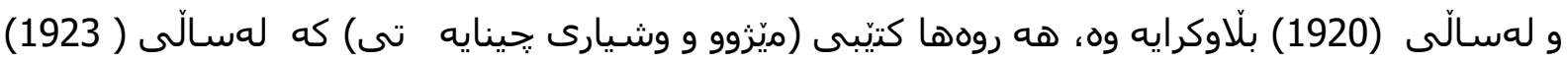

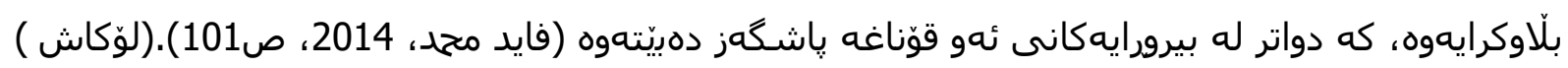

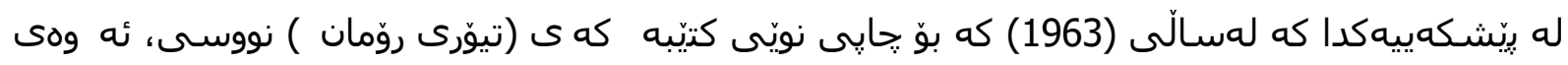

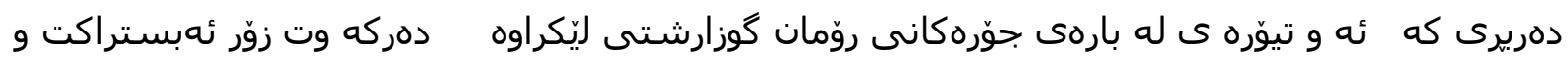

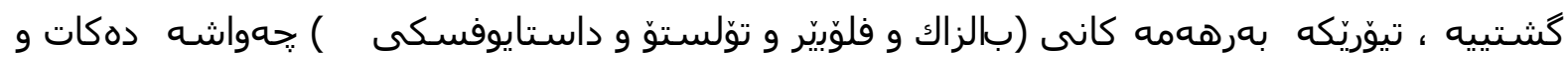

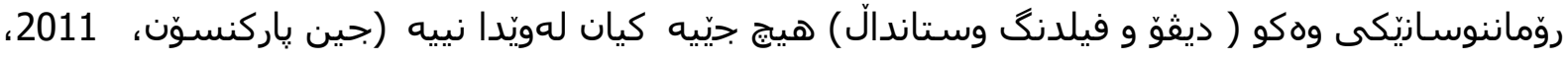

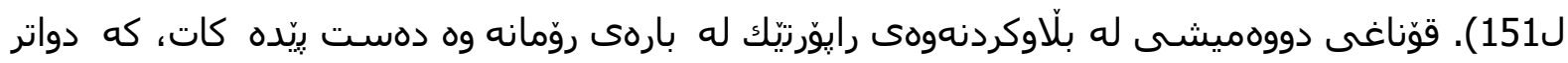

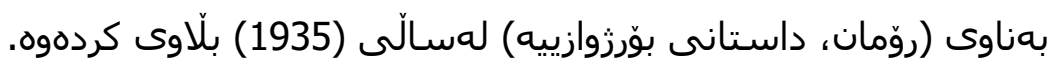

هور :حهنده له كتيّبه كهيدا (تيوّرى روّمان) (لوّكاش) له حهوت بهشـا جهخت لهسهر بيرورايه كانى خوّى

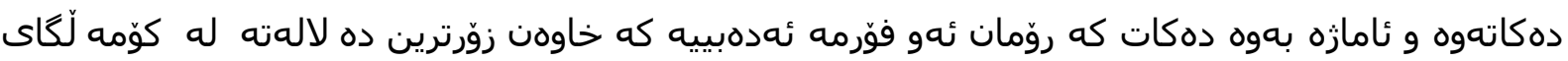

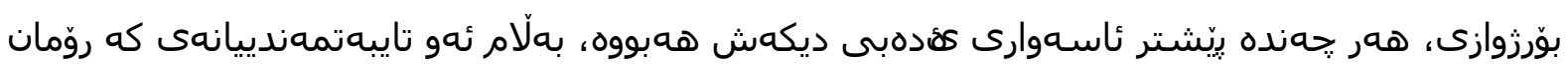

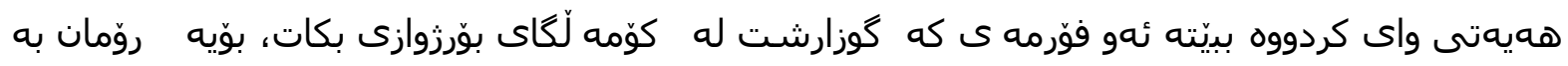

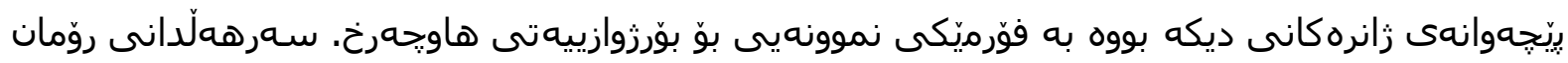

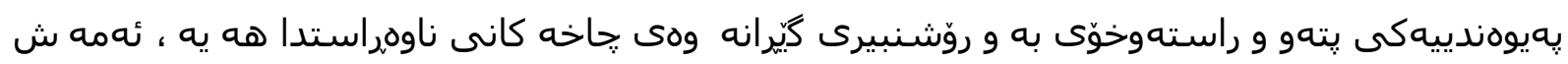

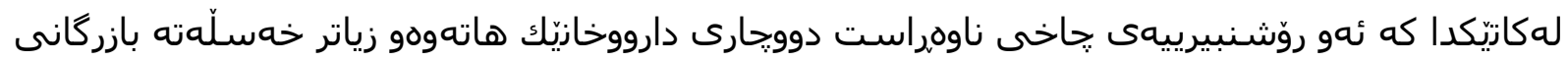

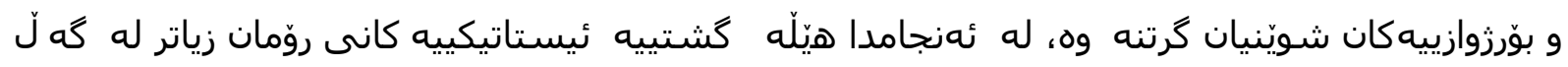

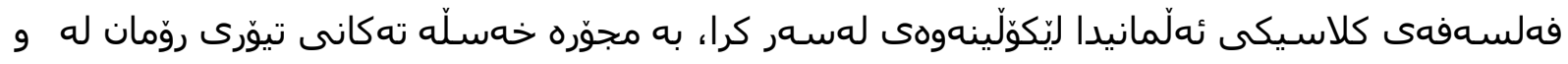

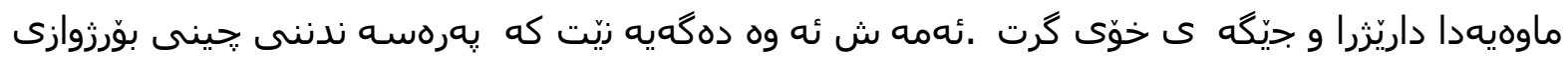


تيوّريّكى تهواو و ريّكخراوى لهبارهى روّمانه وه بِيّشكه ش نه كردووه، به لّكو دياريكردنى خه سلّه تهكانى

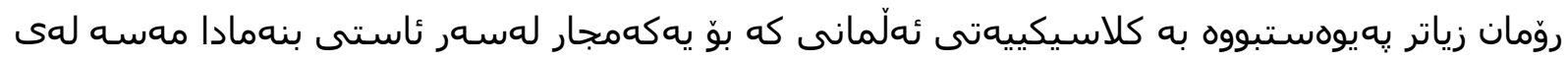
تيوّرى روّمانى خسته به بهرباس و لِّكوَّلِينهوه.

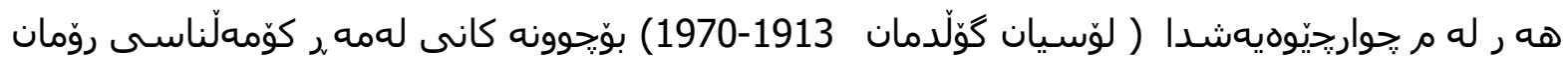

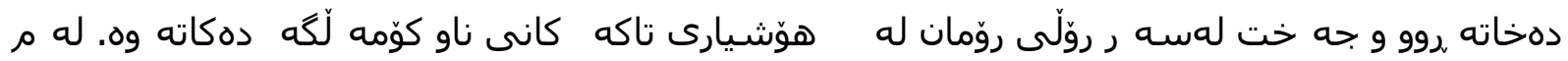

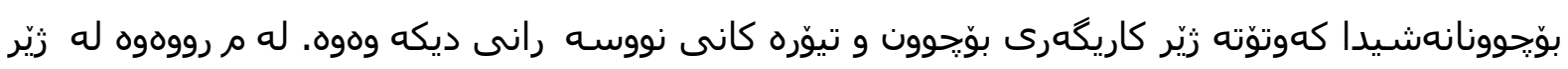

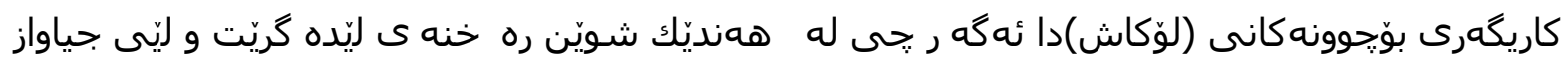

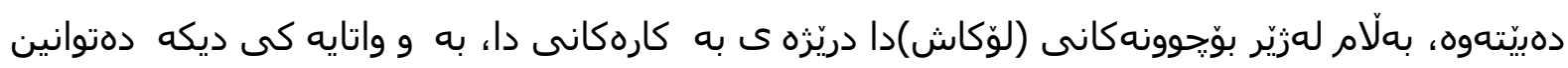

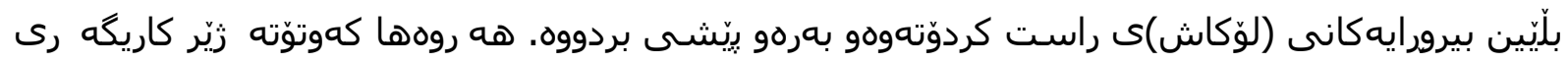

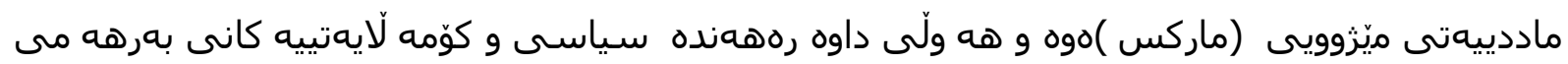

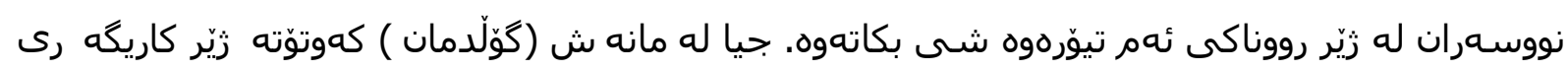

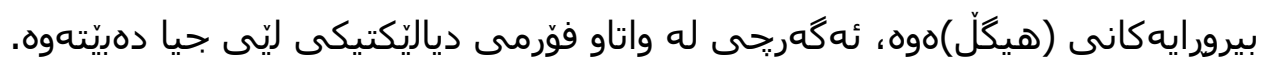

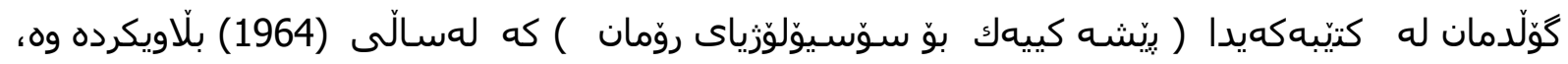

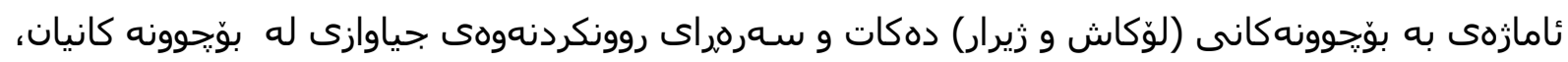

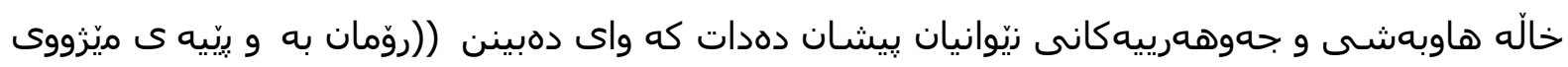

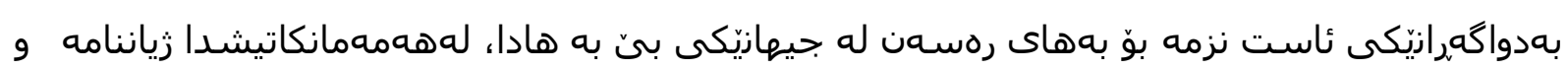

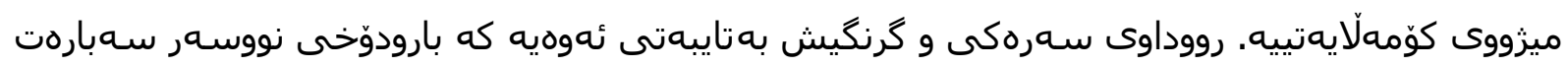

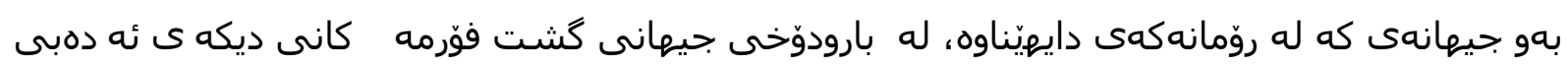

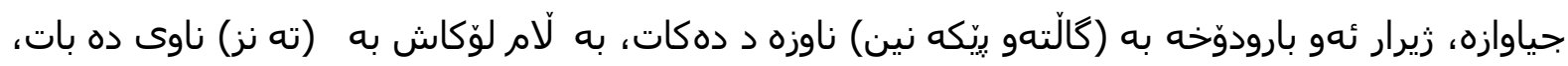

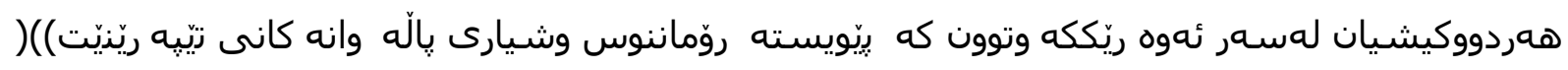

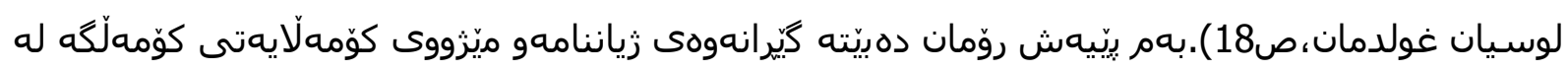

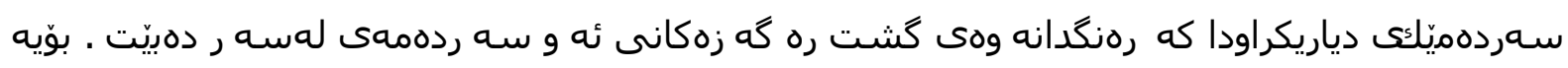

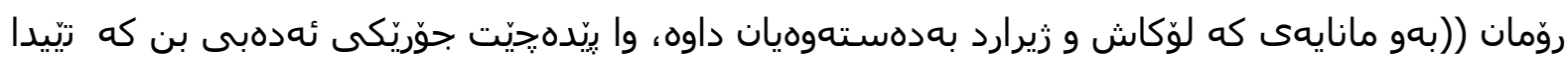

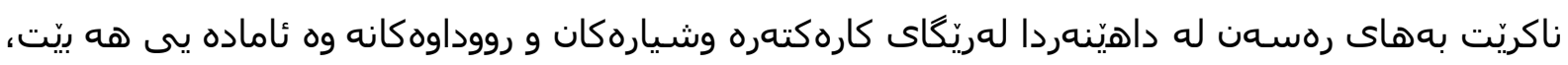

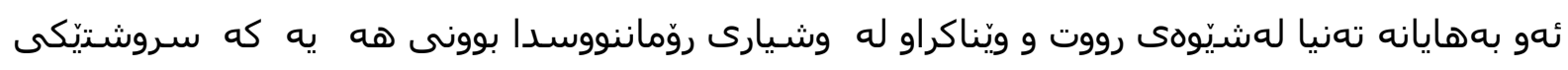

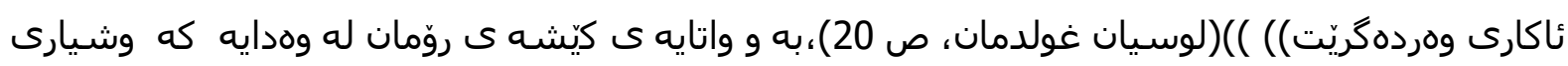

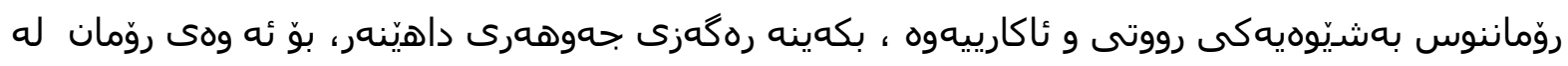

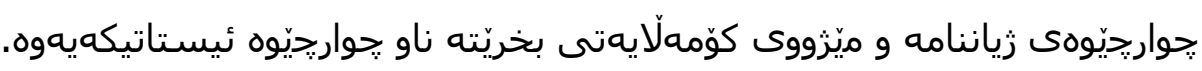

هـر لهم سوّنكهيهوه (ميخائيل باختين1895-1975) دواى ئهوهى يهرده لهسهر بهرههمه كانى لابردرا و

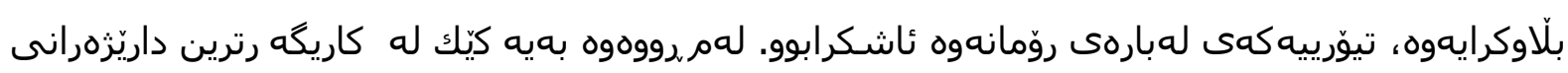

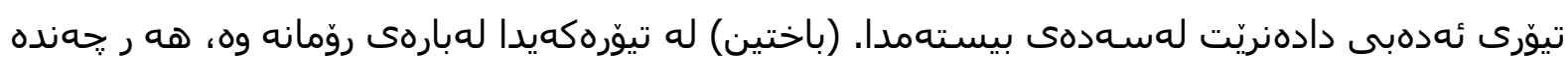

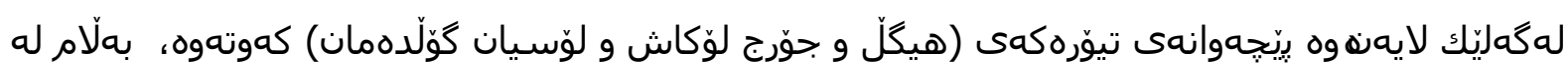

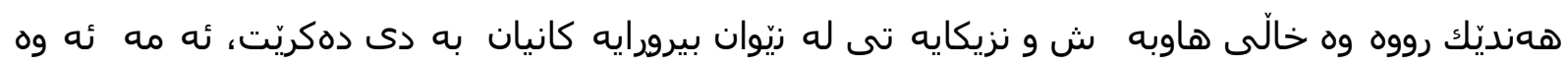

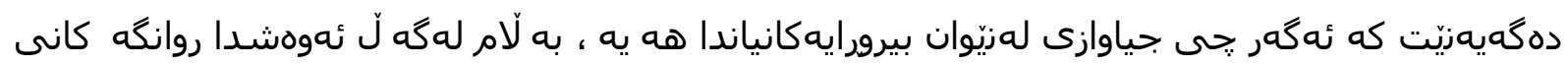

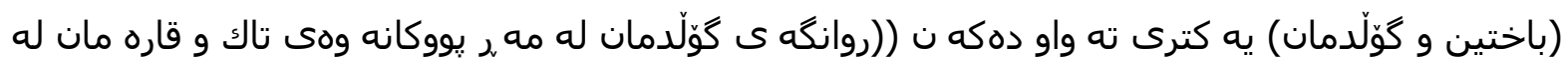




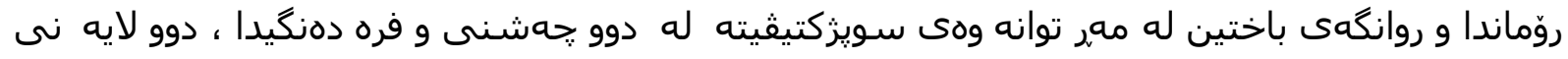

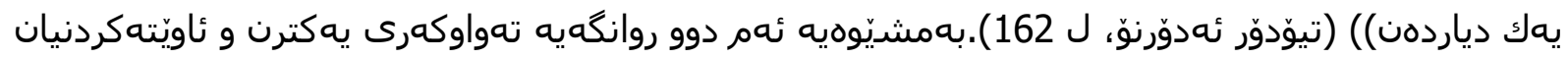

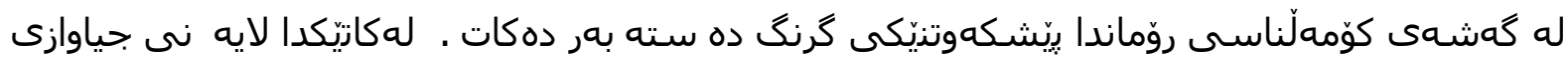

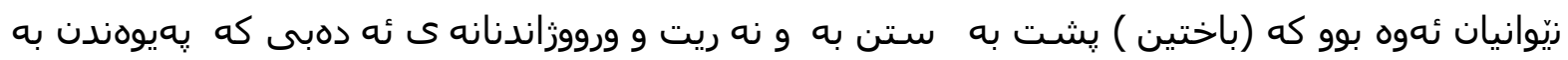

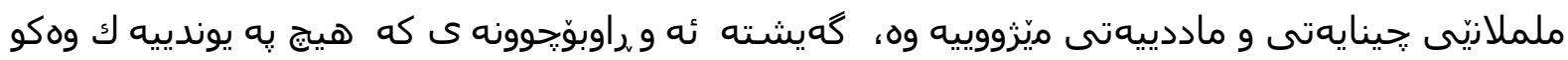

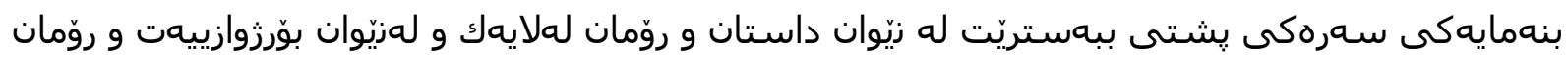

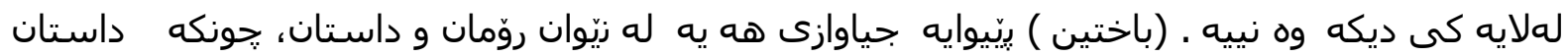

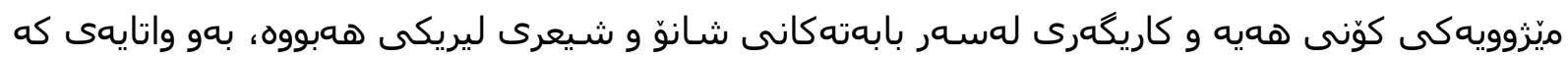

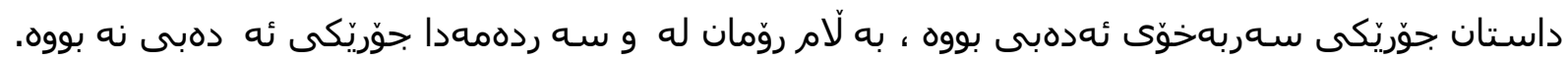

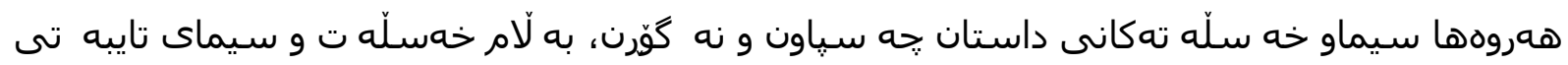

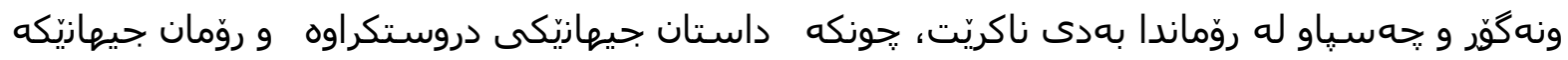

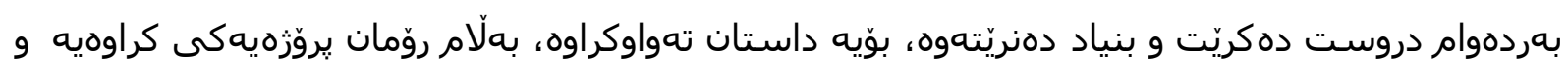

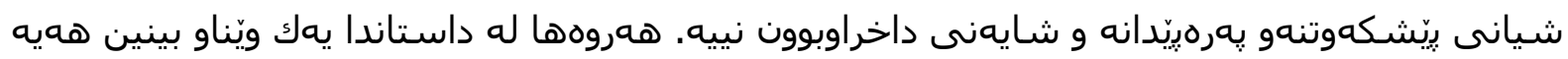

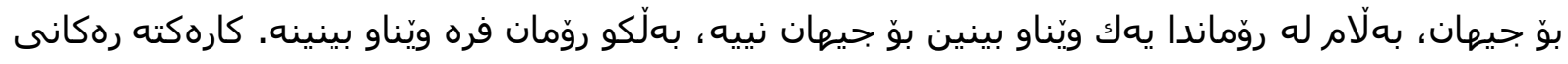

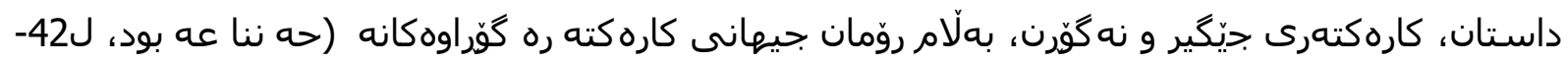
.$(45$

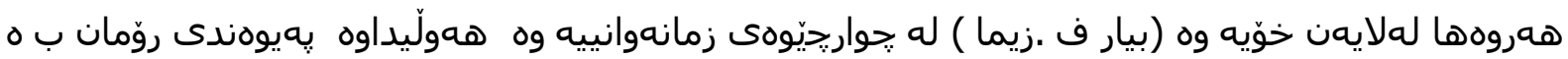

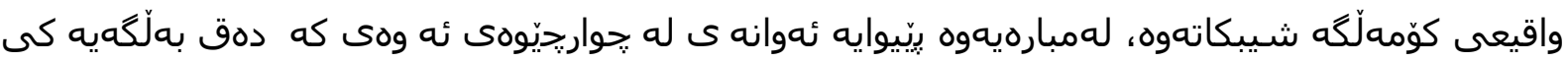

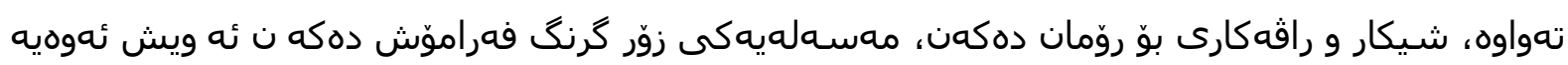

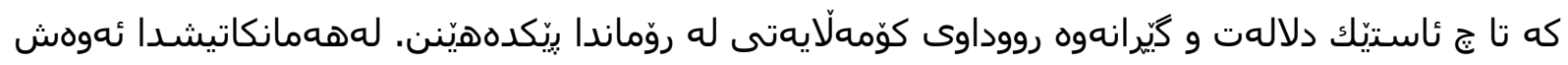

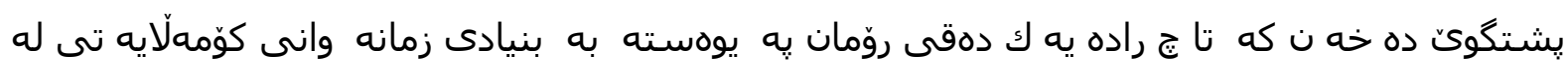

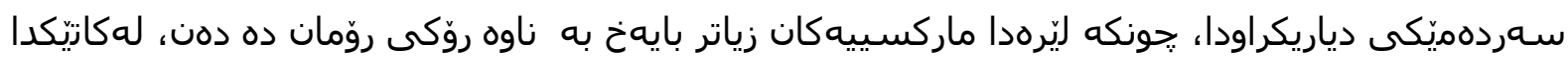

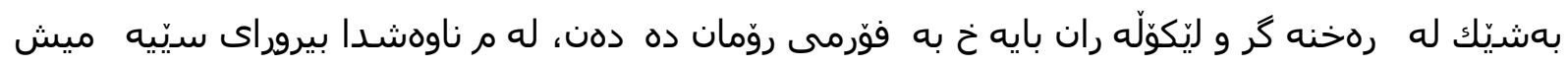

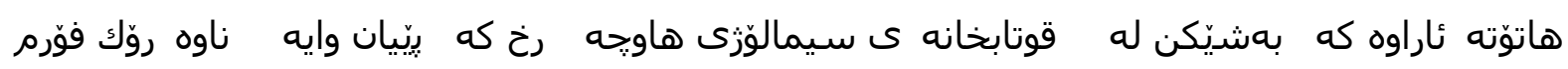

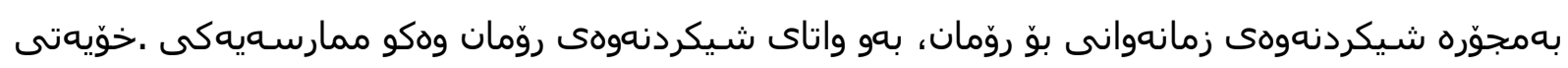

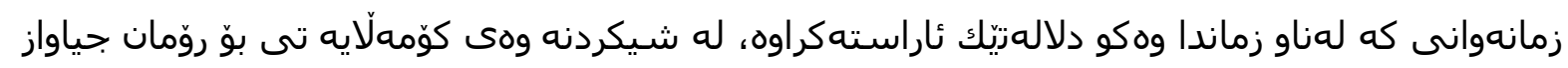

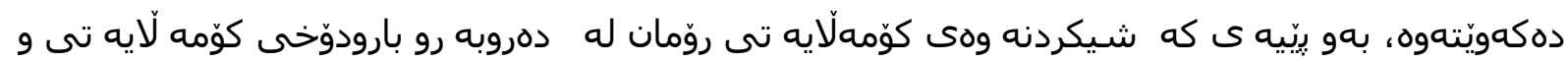

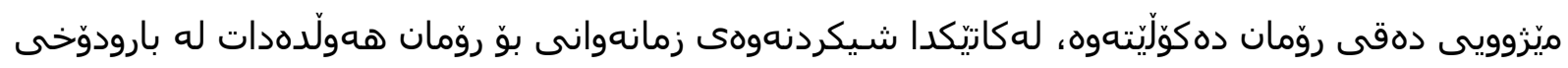

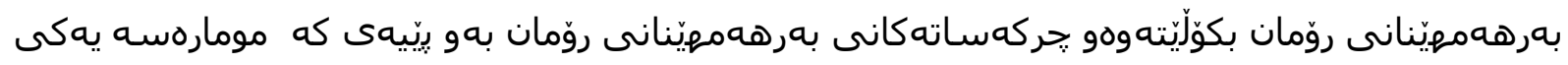

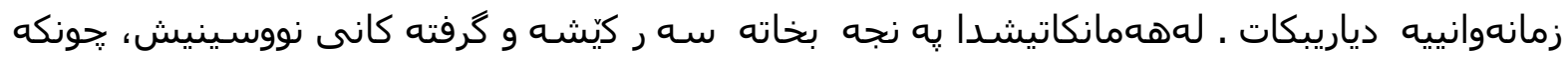

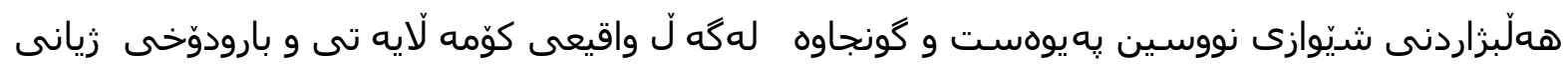

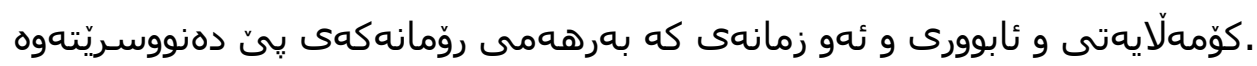

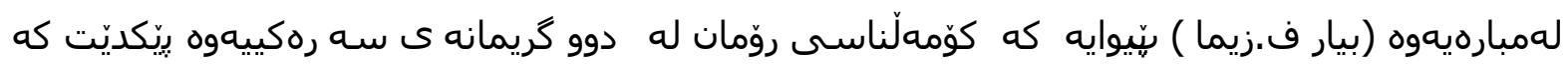

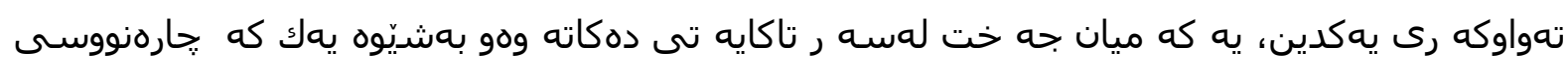

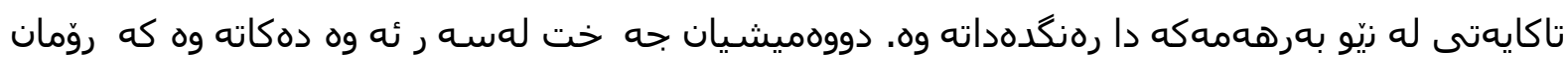


دهوّيكى واقيعييه و همموو ناراسته زانستييهكان و ئهو ماددييهته خحينايهتييهى كه ويّناى ده كات، له خوّ

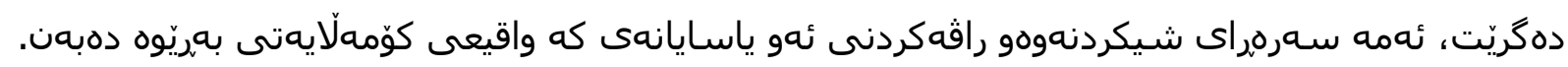

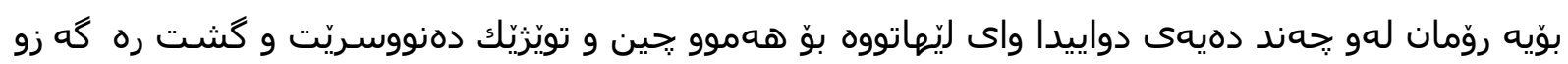

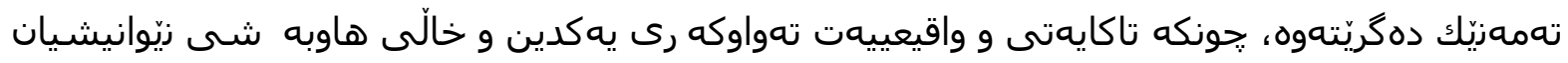

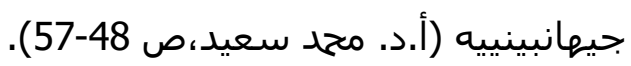


تهوهرى دومر

بهرجهستهكردنى بابهته كوّمَلايهتييهكان

كوّملّكَهى كوردى لهزيّر كاريكهرى جهندين هوّكارى راميارى و كوّمهلايهتى و ميّزوويدا، خاوهنى كولتور و

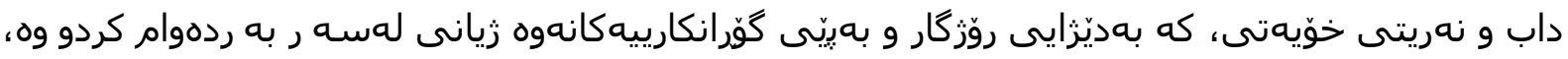

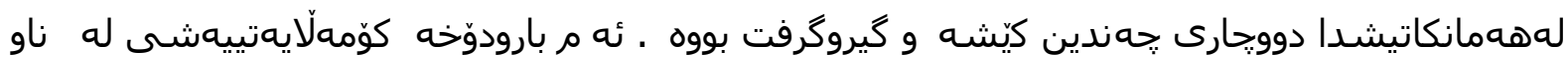

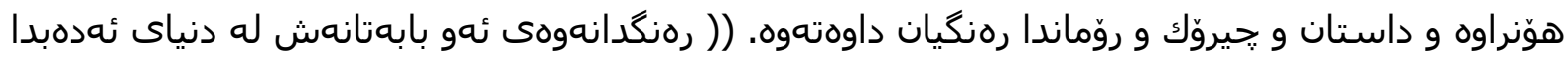

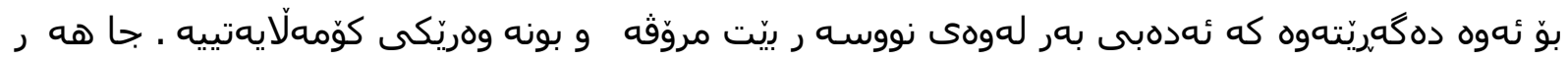

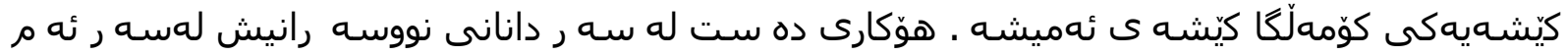

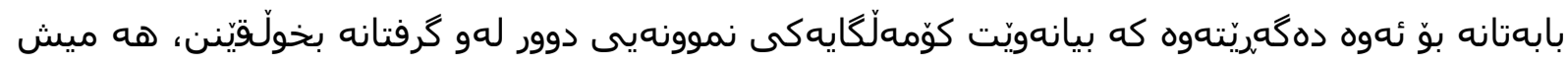

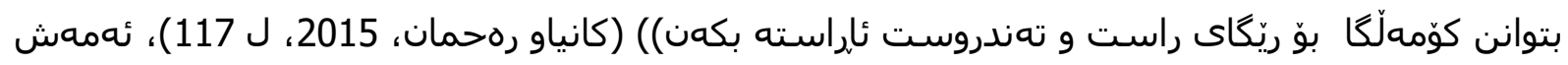

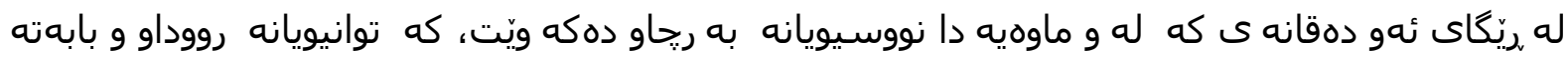

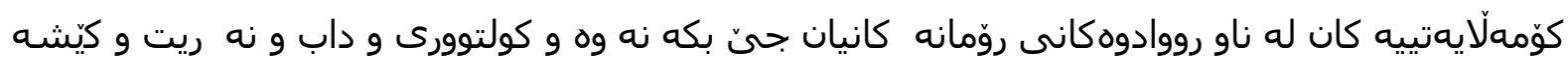

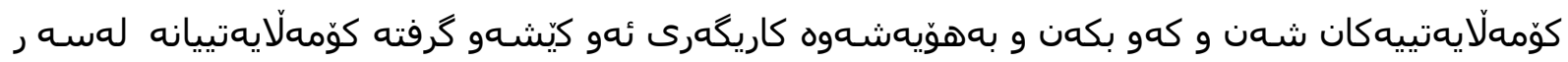

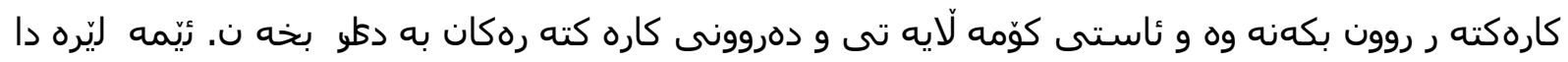

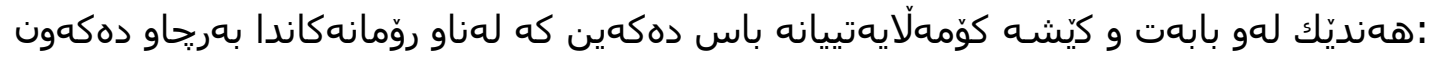

\section{: _ نهخويندهوارى}

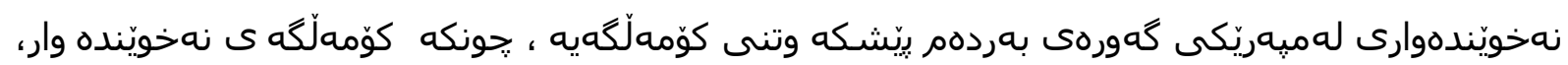

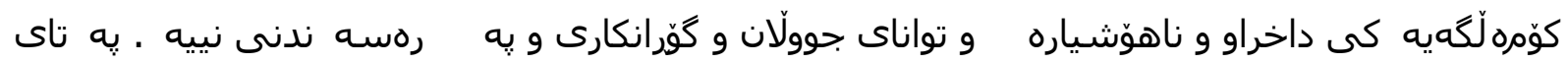

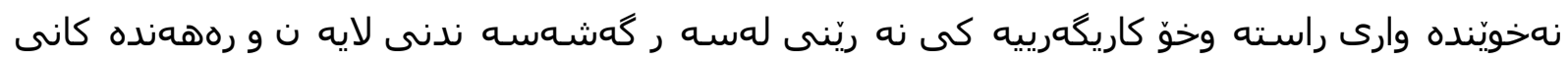

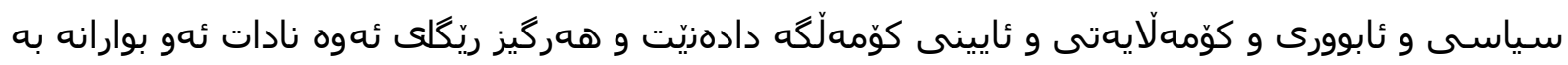

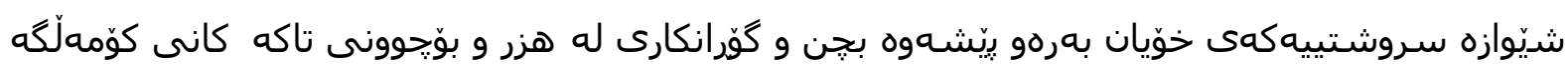

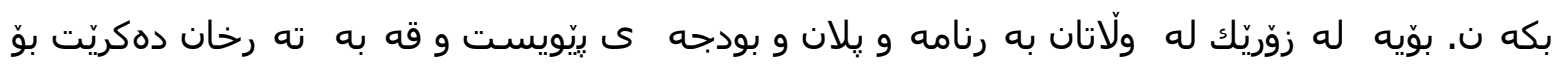

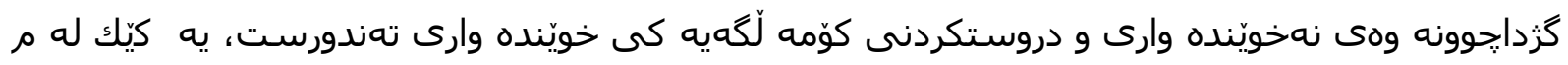

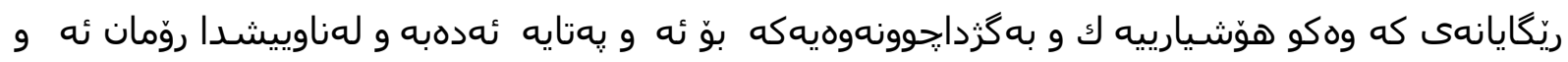

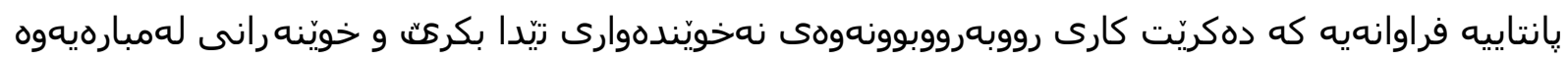
وشيار بكريّنوهوه

لهمبارهيaوهله روّمانى (ظانى كَه ل)ى (نيبراهيم ئه حمه د)دا نهخوينده وارى لهلايaكه وه وهكو

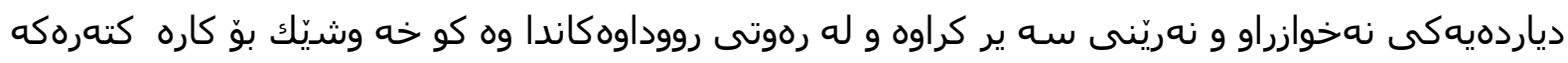

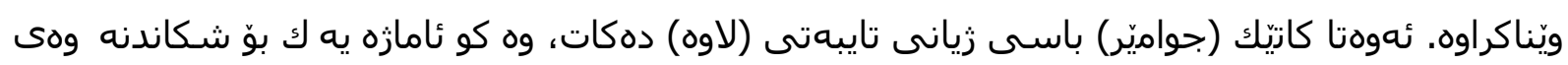

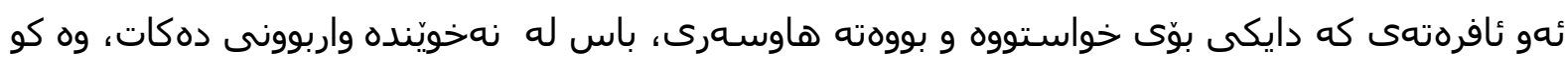

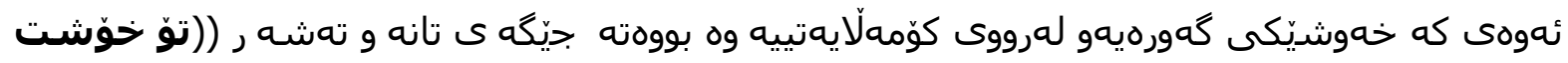

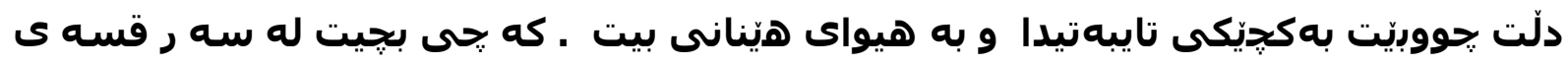




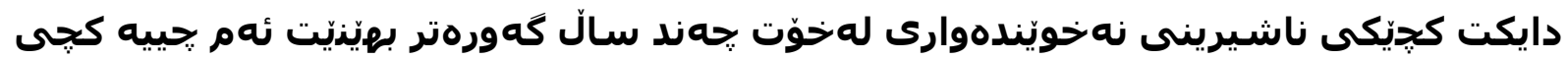

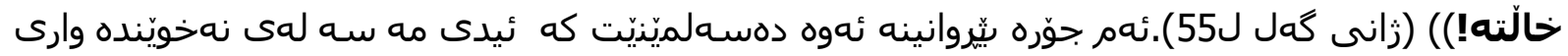

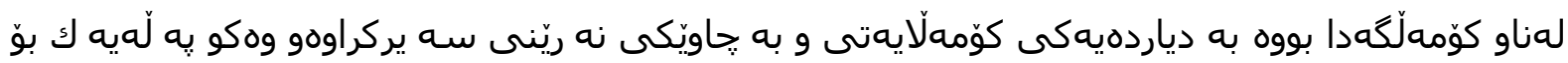
كهسايهتييهكه هاتوته زماردن.

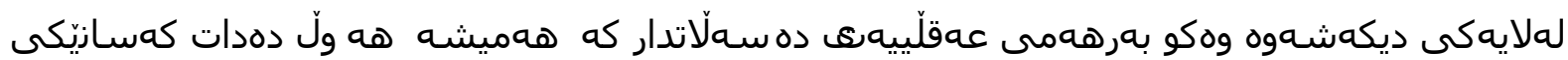

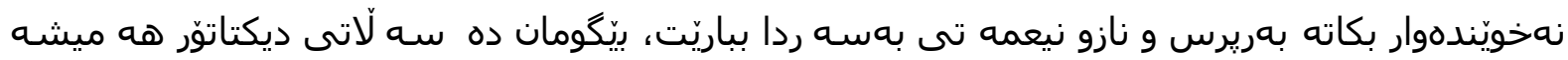

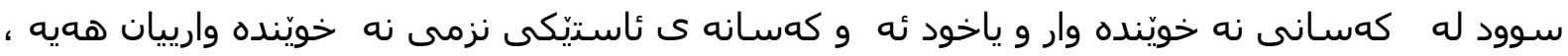

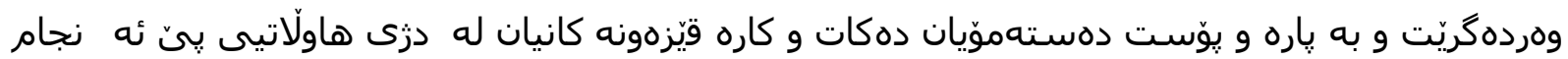

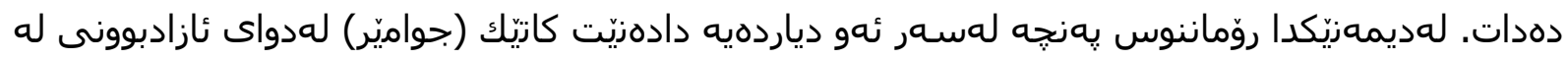

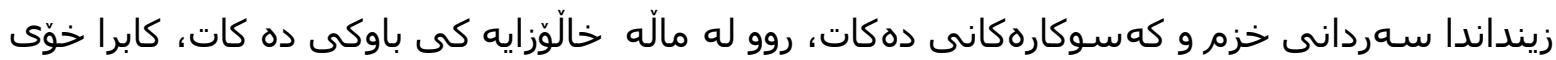

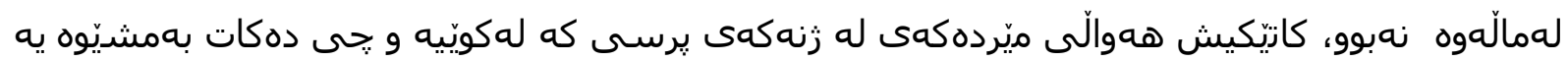

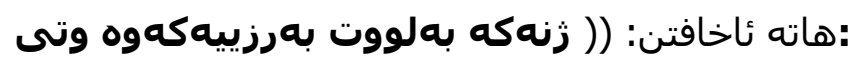

_ مaنمووره، لهدايهرهيه؟

:حواميّر به حهبهسازيكهوه برسى:

\section{-}

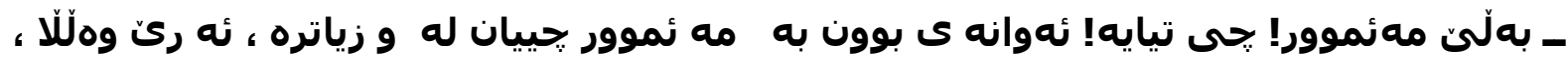

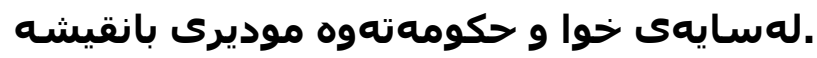

\section{ـ موديرى بانق؟ سه يره! مه بحيدى خالِوّام خويّندنى سه رهتايى ته واو نه كردووه، جحوّن}

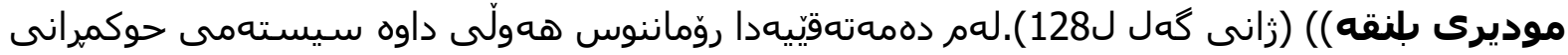

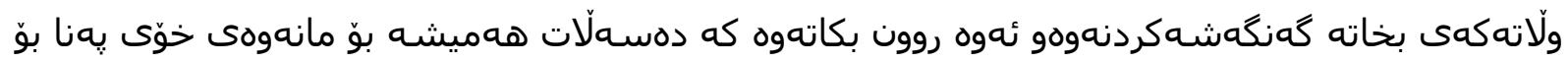

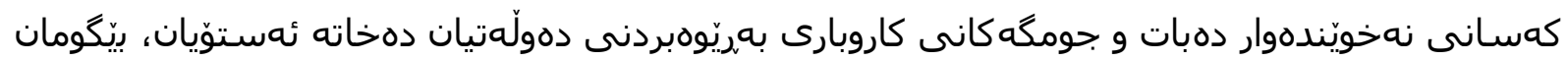

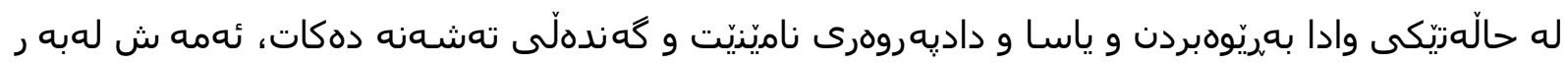

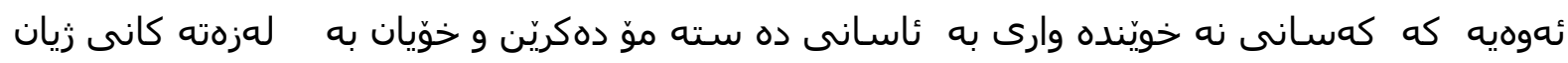

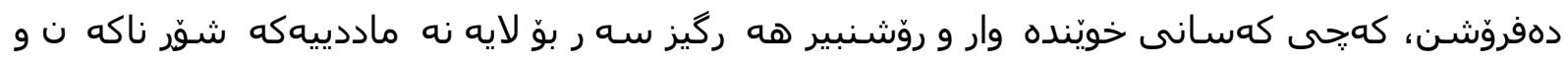

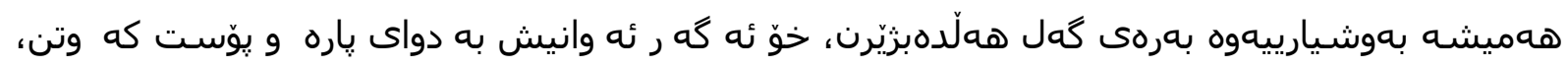

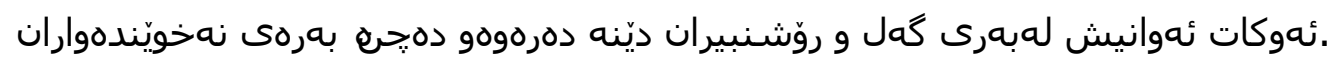

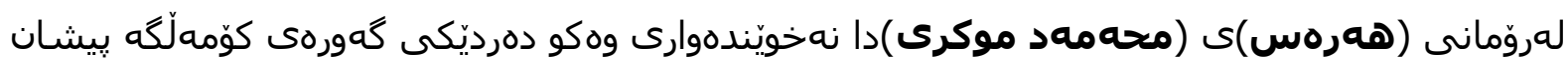

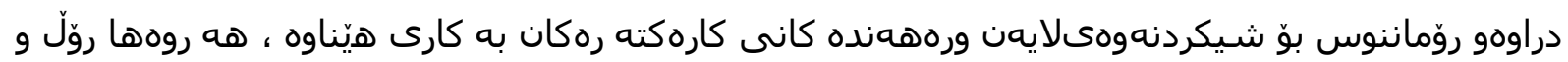

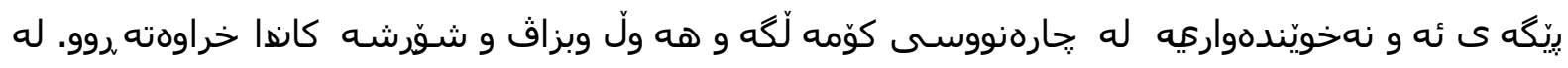
باسكردنى (حهمه)ى كارهكتهردا ئامازه بهوه دهكات كه نهخويندهوارى ريّكر نييه له شوّرش و و رايه ريندا،

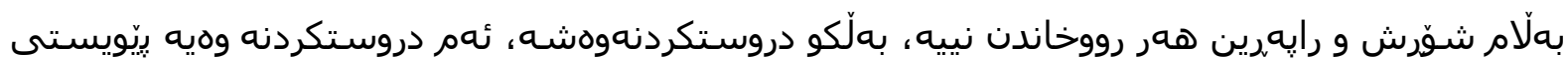

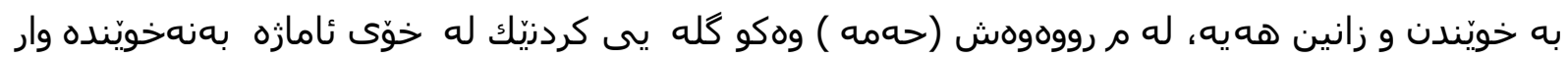

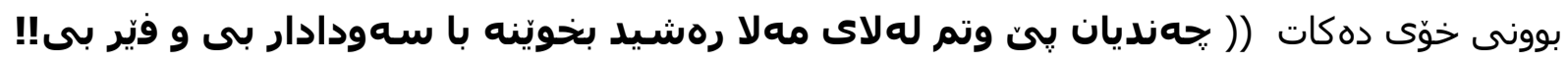


كهحى بهقسهى كهسم نهكرد، ههر خه ريكى قيته قيت بووم ، دهنا زيّيستا منيش ههنديّم

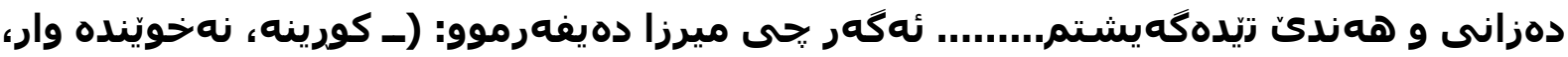

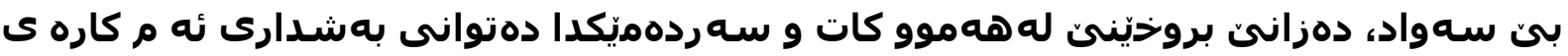

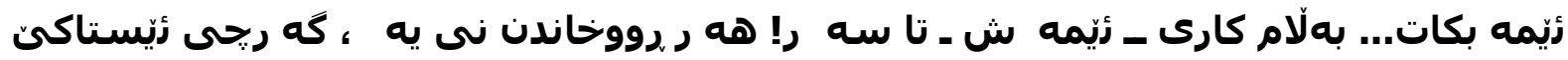

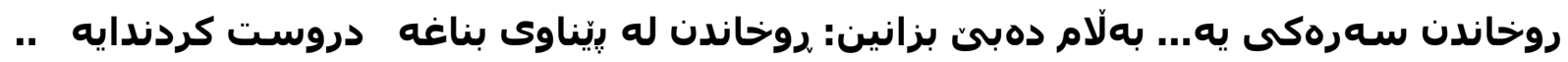

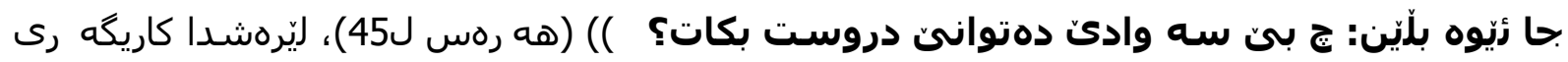

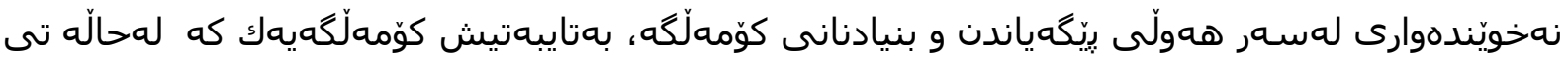

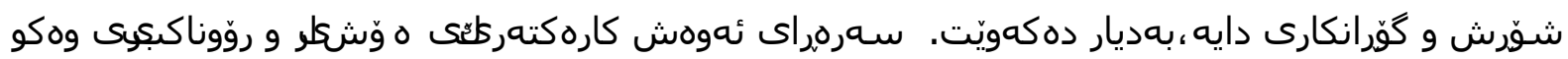

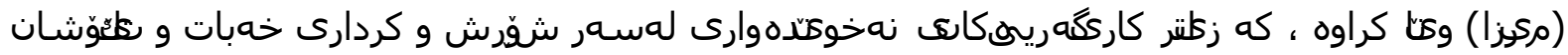

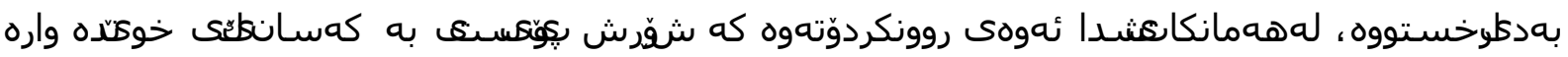

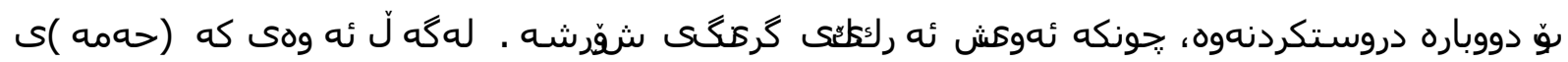

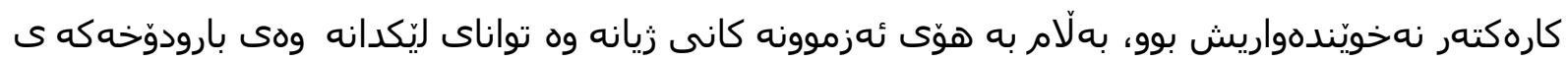

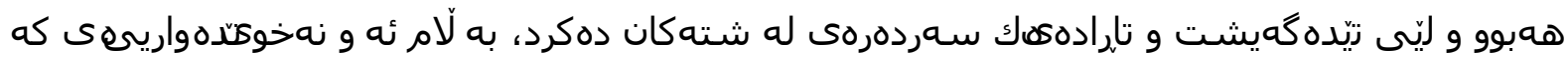

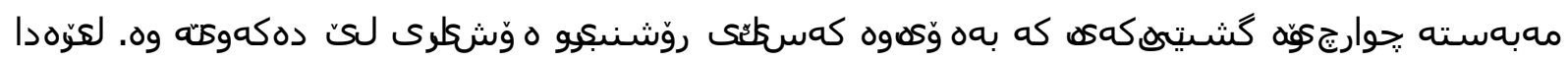

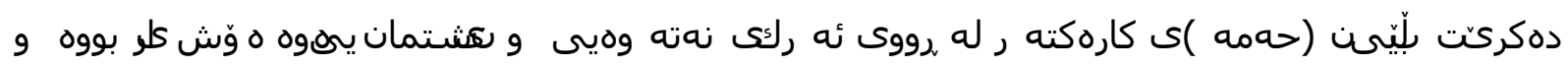

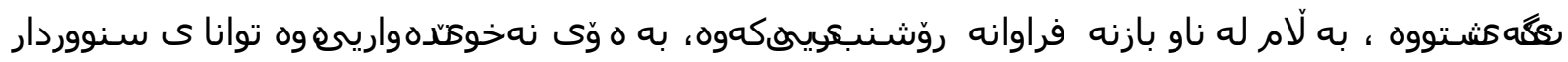

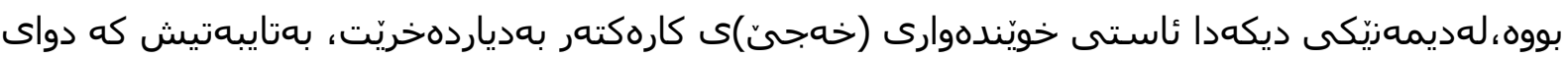

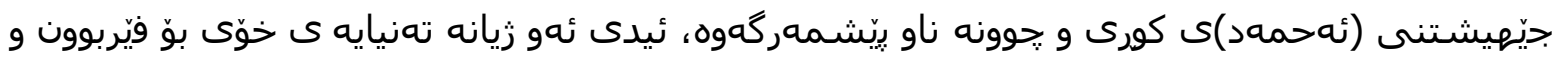

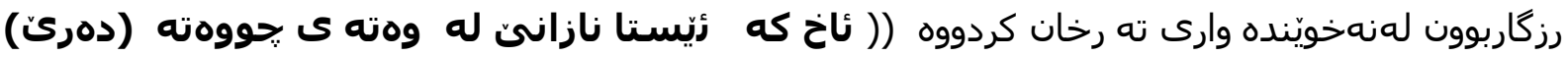

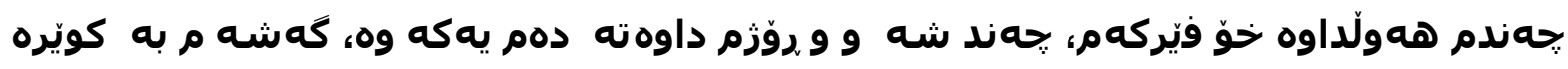

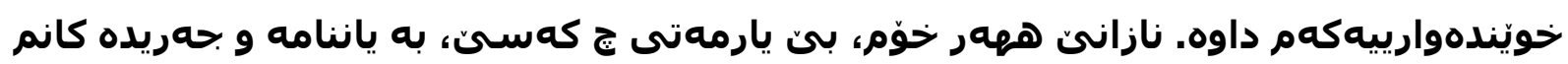

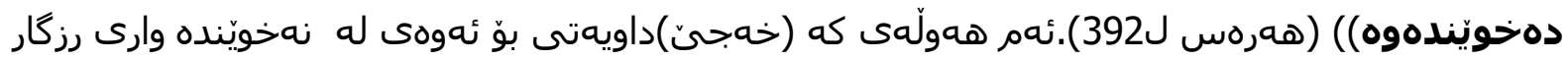

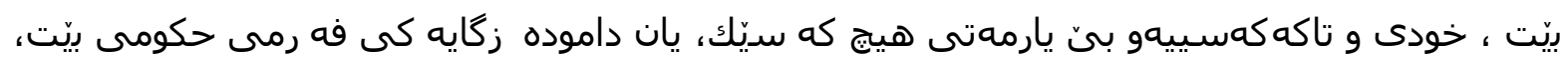

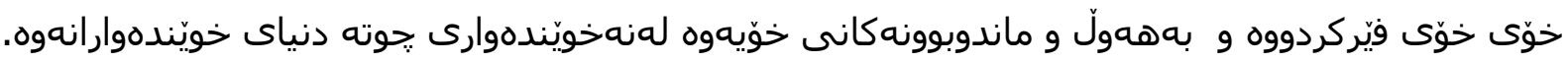

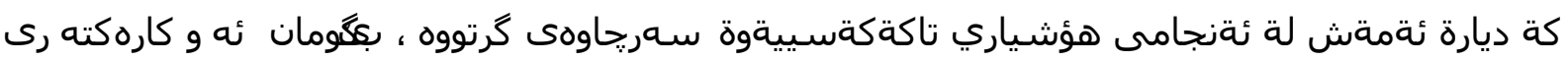

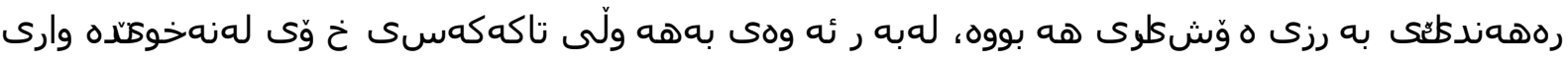

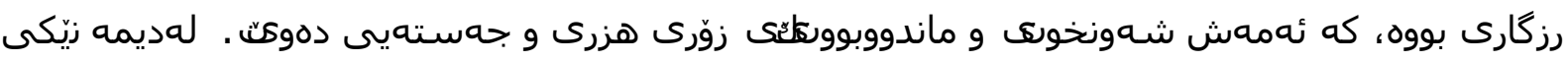

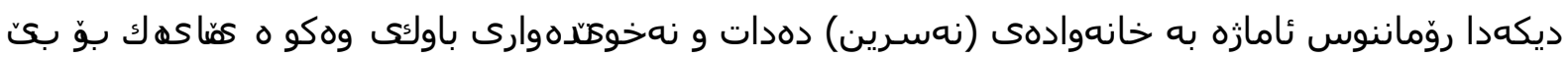

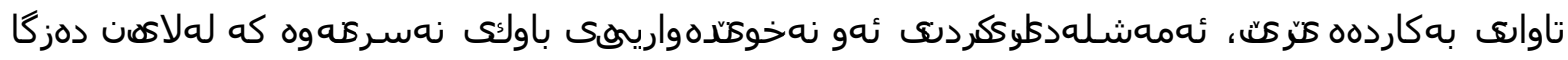

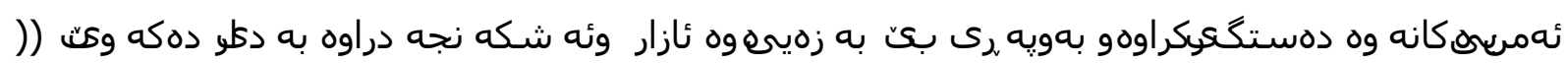
ئهوى بهو باوكه نهخويّندهوار و بهستهزمانهى دهكهن مهَّهر ههر لهدهستى (ئهوان)دا بِّيت

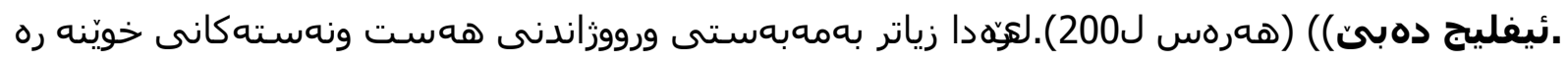

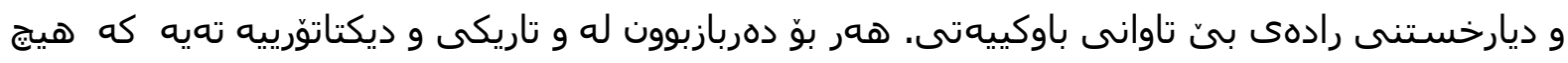

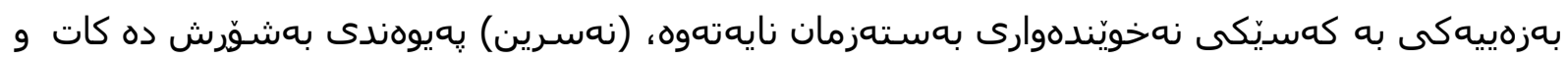

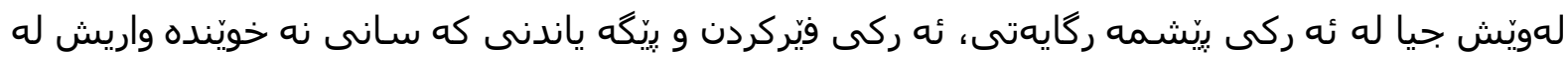

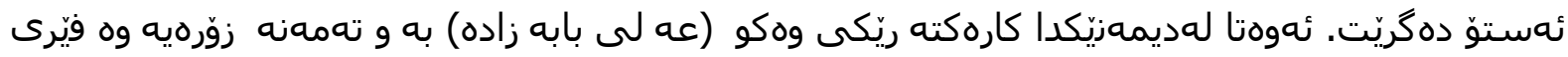


خويّندن و نووسين ده كات و له تاريكيى نه خوينده وارى رزكارى ده كات ( له م ماوهيه دا به هوّى نهسرينهوه فيّرى خويّندهوارى بوو، زيرهكى يهكى ئهو توّى نواند كهر كه س له و تهمهنه دا

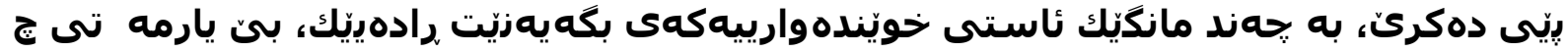

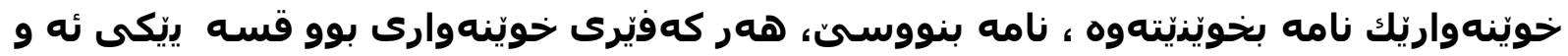

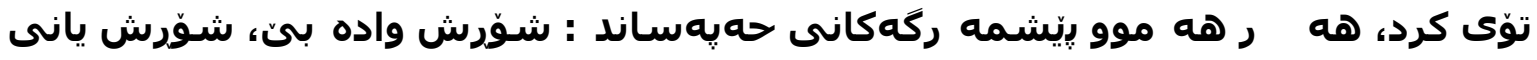

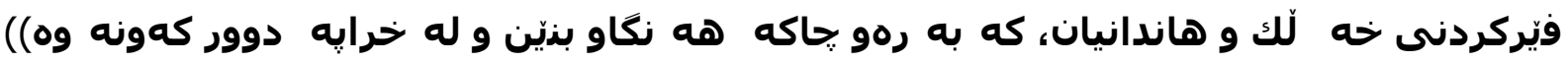

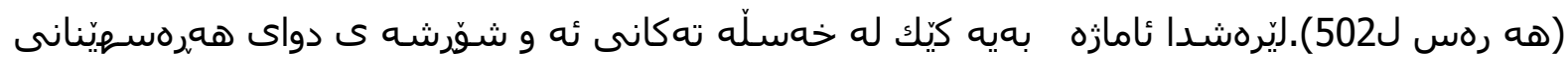

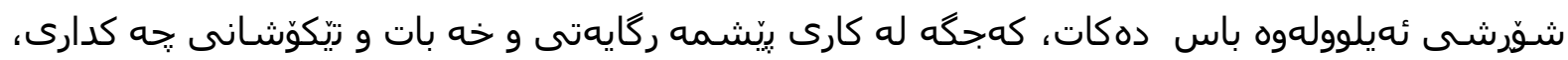
خهبات وتيّكوّشانى روّشنبيرى و يه روهردهييشى له ئهستوّ كرتبوو، ئهمه خالّى جياكه رهوهى بوو له

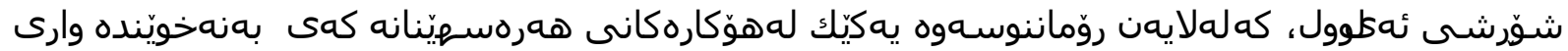
كادير وبهريرسهكانييهوه دياريكرابوو. ئهمش كارهساتيّكه بوّ خوّى، كه بهريرسيارهتى شوّرش لهدهست

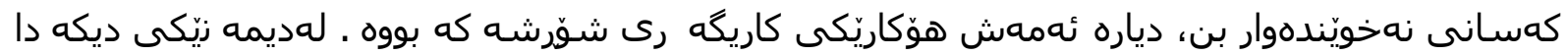

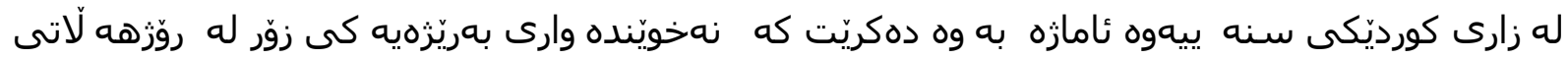

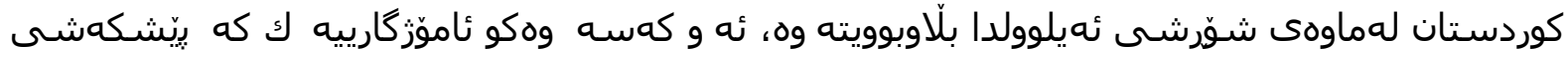

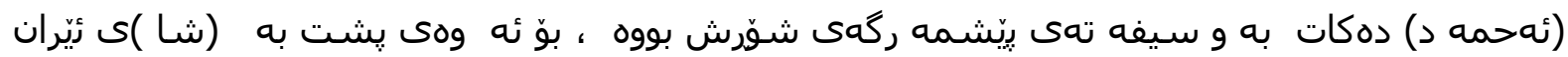

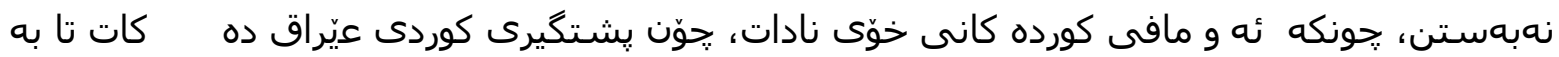

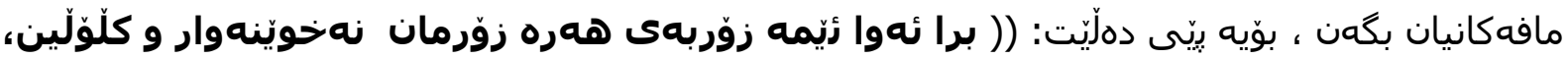

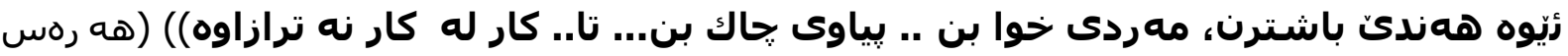

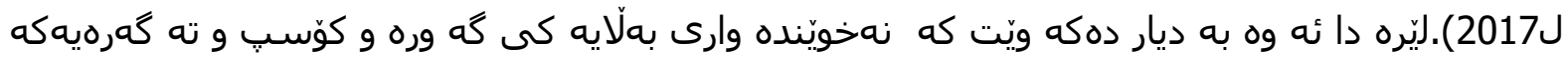

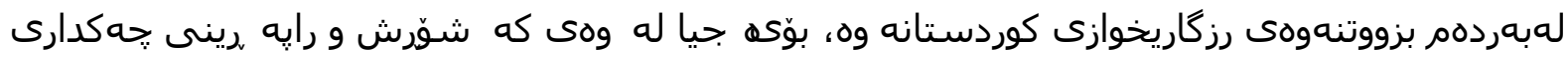

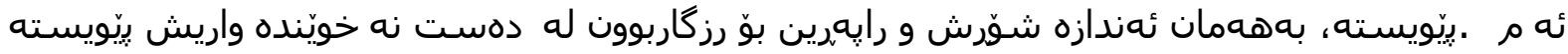
جهخت كردنهوهكه لهسهر نهخوكّدهوارى لملاكهن روّماننوسه وه بوّ دلوخستنى قه وارهى ئه و كاره

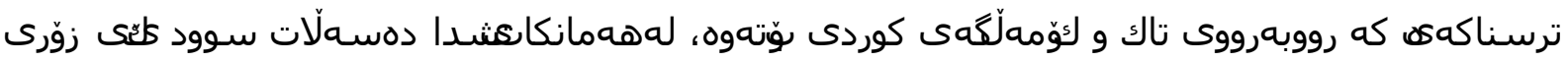

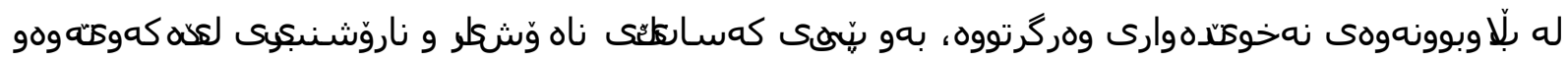

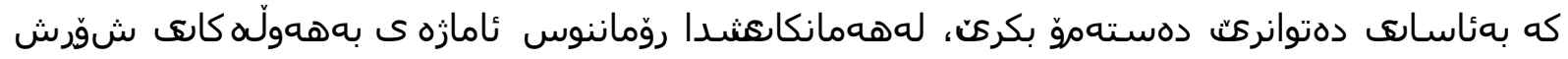

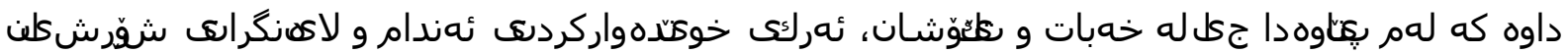

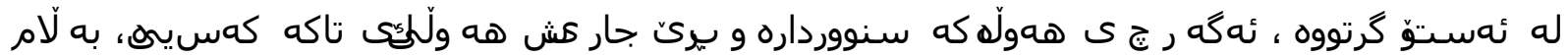
كاركگهُرى خوّى همبووه لهناو شوّرشـا.

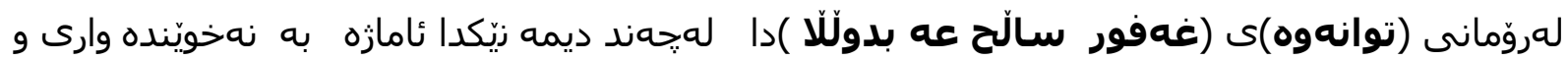

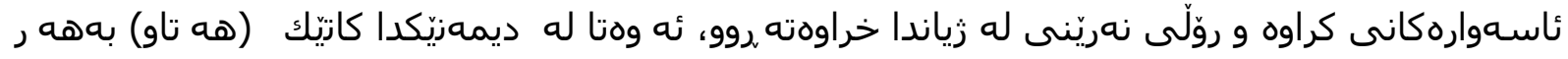

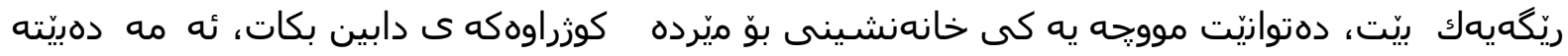

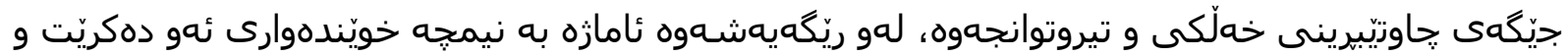

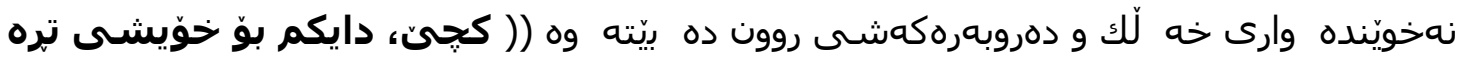

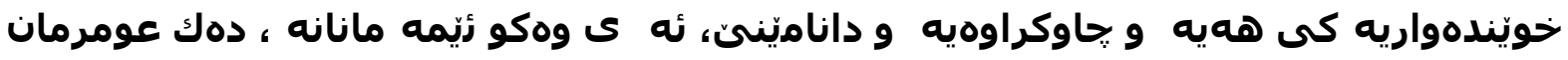

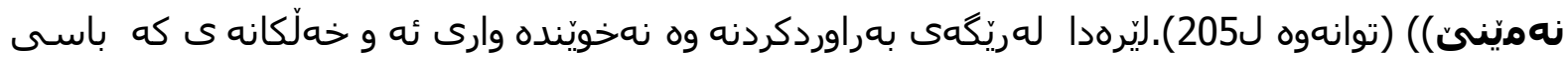

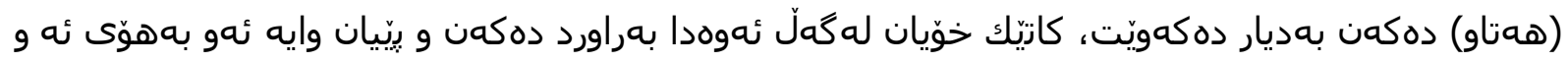


نيمجه خويّندهوارييهى كه ههيهتى توانيويهتى زيان و كوزهرانى خوّى باشتر بكات. سهرهراى ئهوهى كه

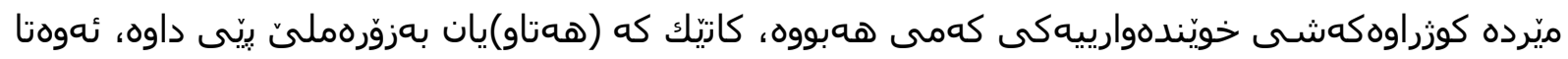

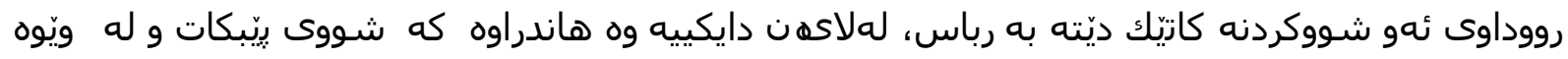

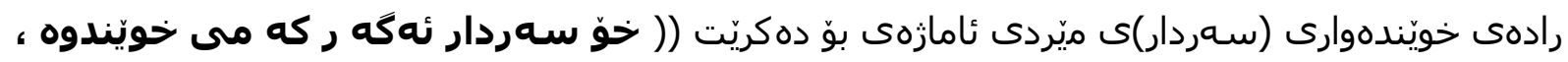

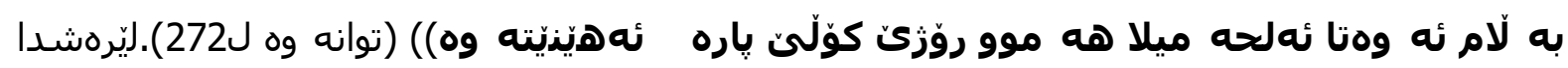

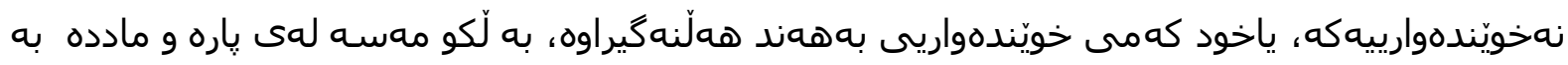

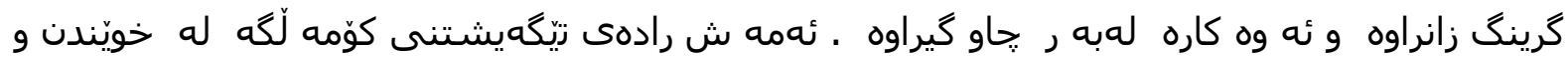

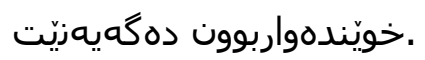

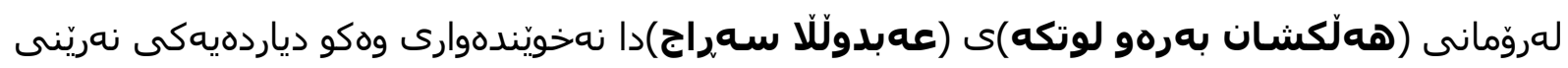

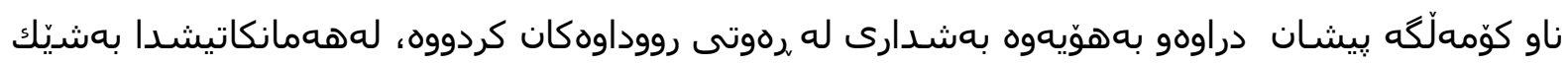

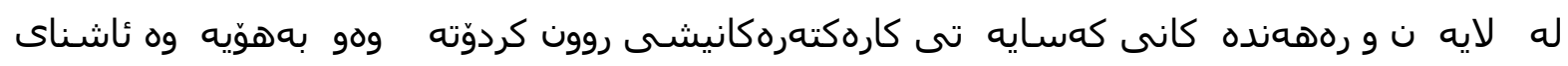

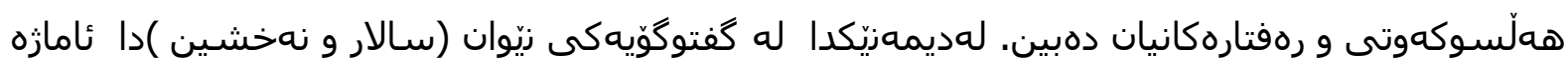

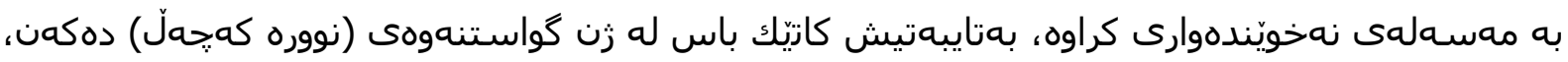

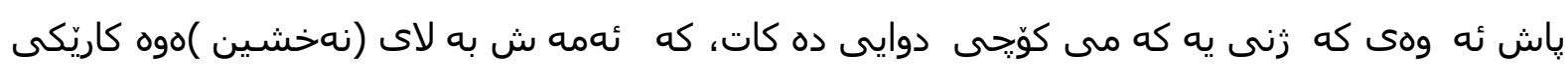

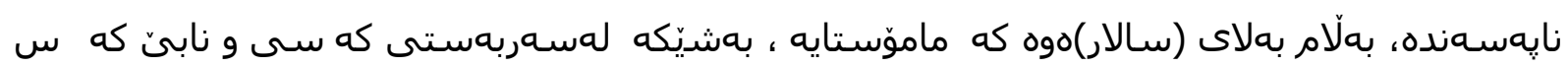

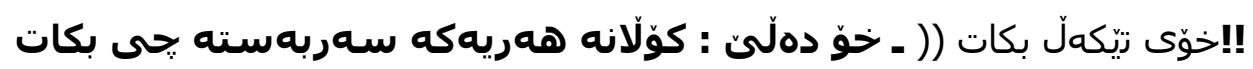

\section{!ـ لهقسهى خوّم نهَّهراومهتهوه و باشهَّهز نيم}

ـ توّ له كن خوّت خويّندهوارى و دهبى ده رس بوّ نه خويّنده واريّكى وهك من داده يت ! زيّستا

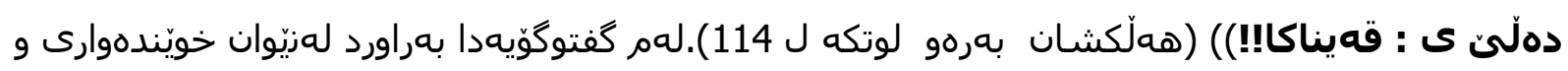

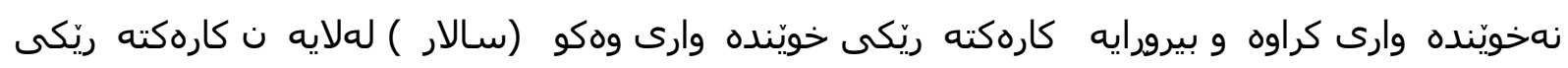

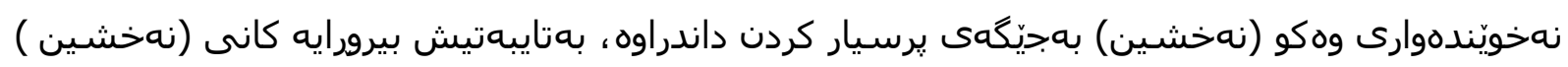

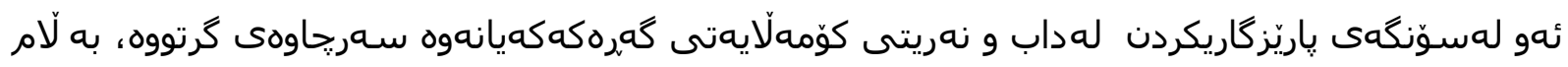

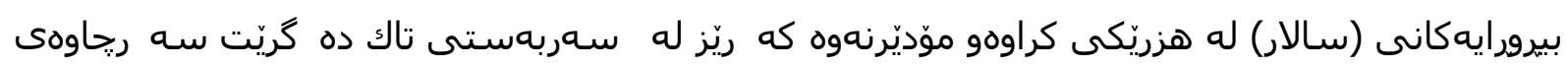

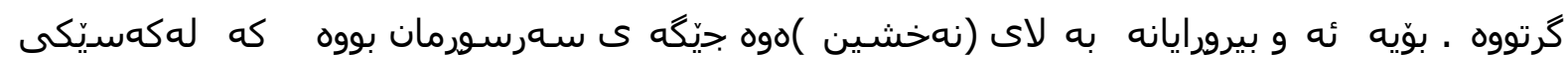
خويّندهواريشهوه راگهيهندراوه بوره

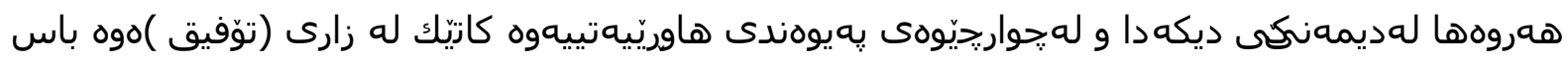

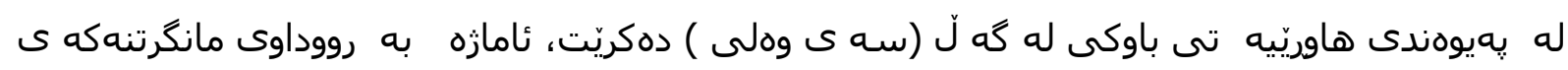

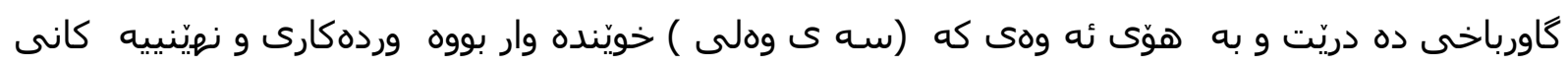

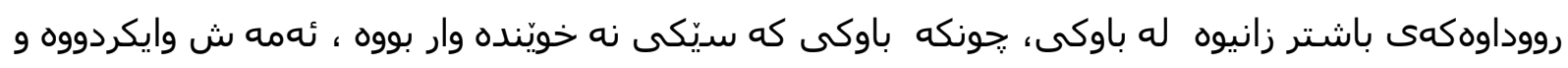

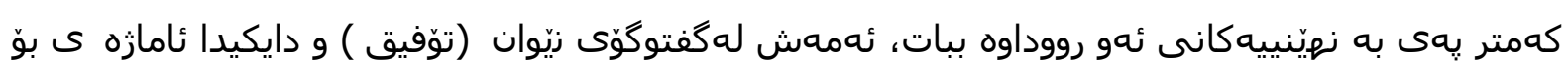

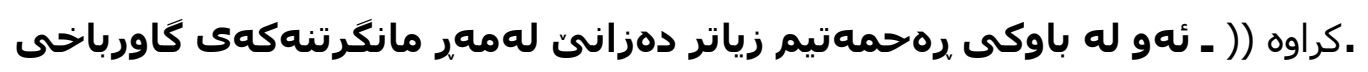

ـ : جونكه سهى وهلى كه موّكهيه ك رهش و سبيى بحياده كاته وه، باوكت نه خويّنده وار بوو،

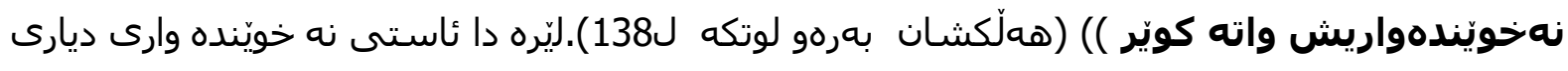

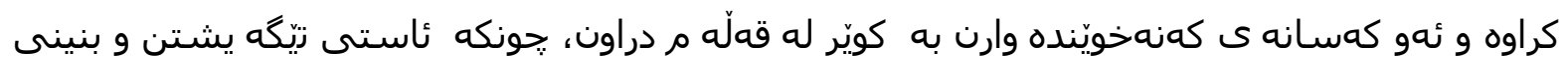


رووداوهكانيان سـنوورداره و ليّكدانه وهيان بوّ شته كان كه متره. لهديمه زيّكى ديكه دا باس له كهسيّك

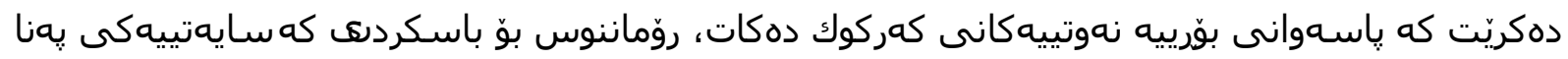

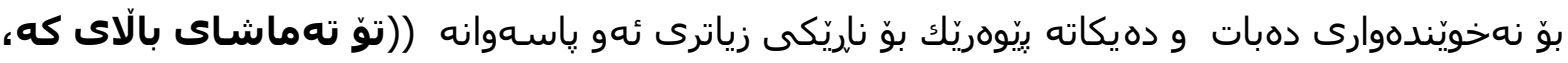

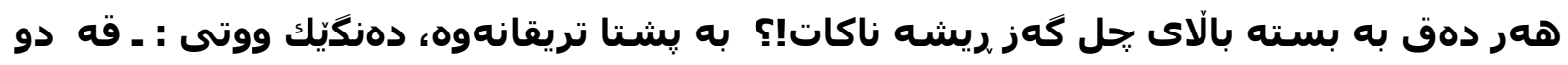

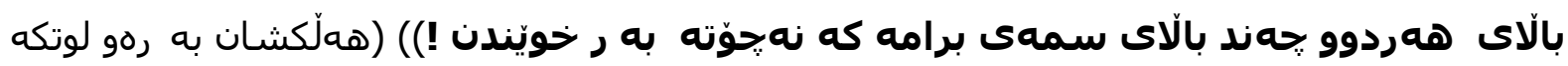

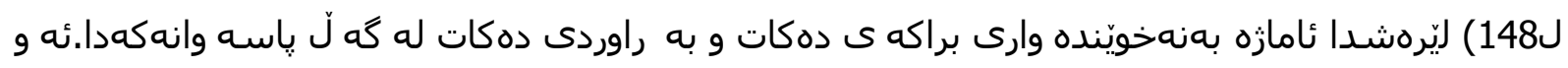

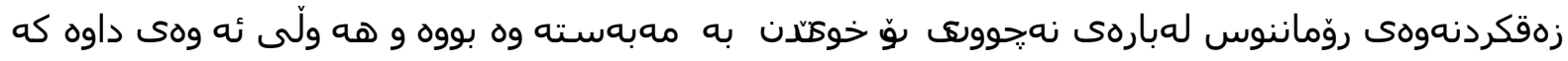

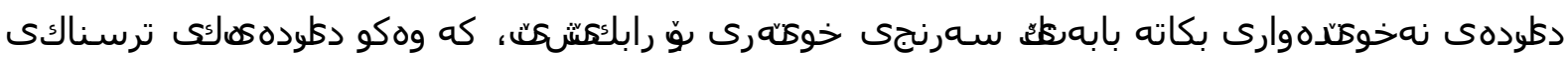

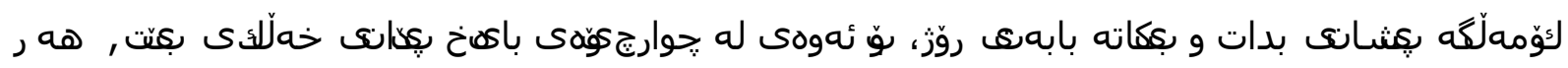

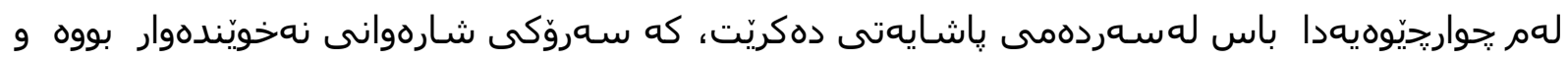

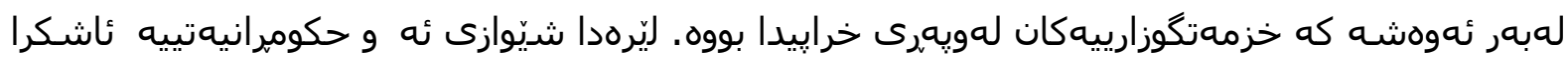

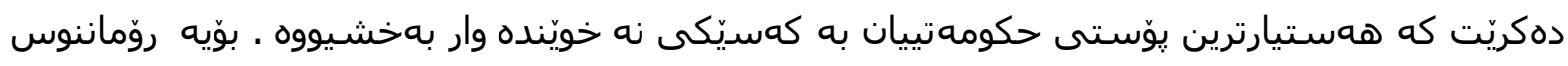

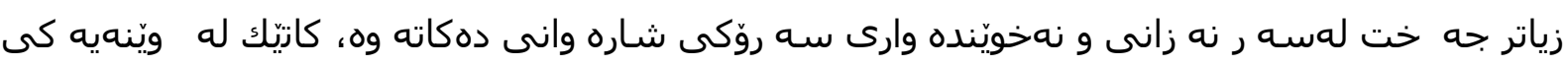

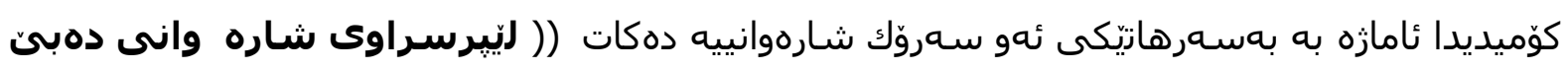

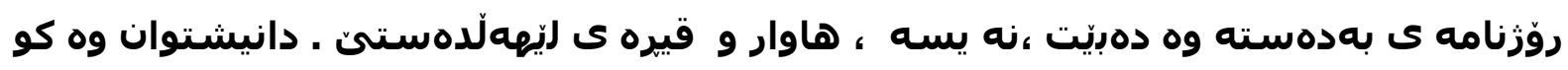

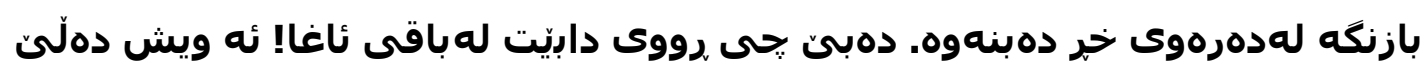

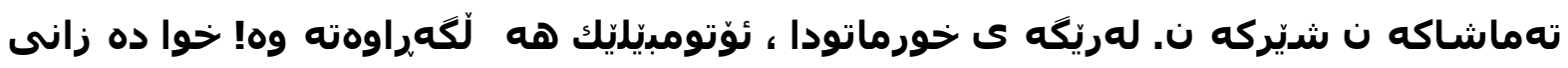

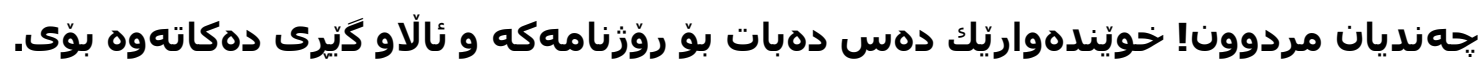

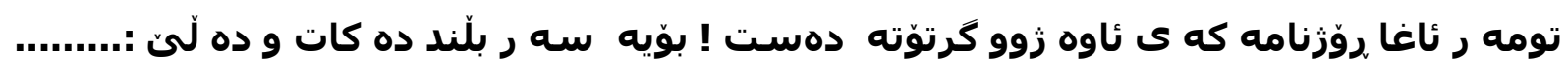

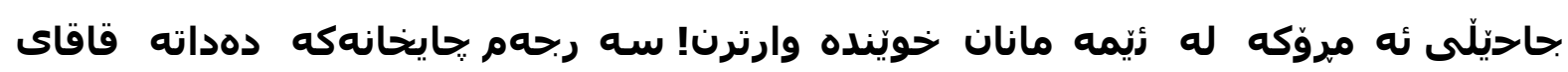

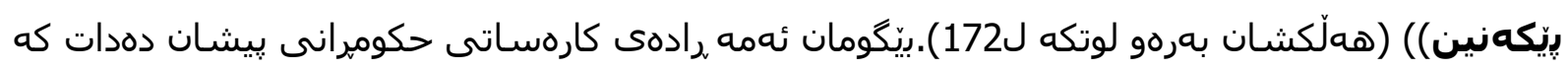

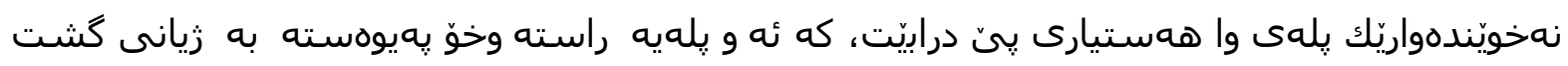

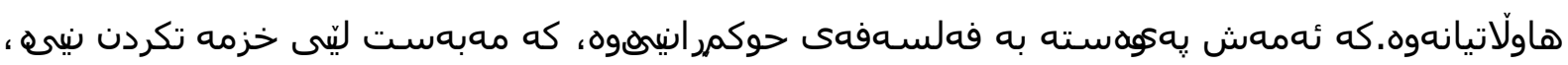

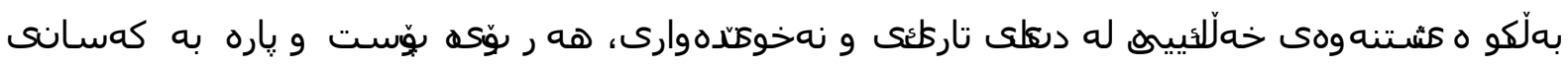

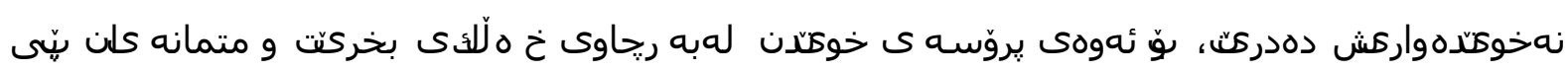

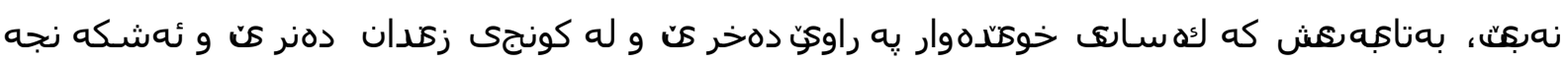

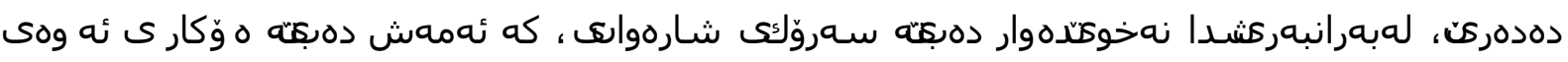

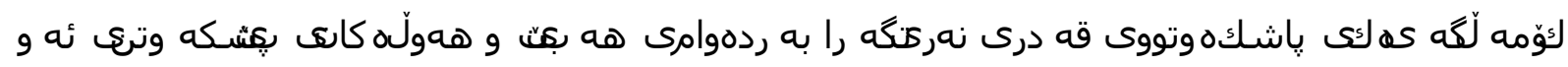

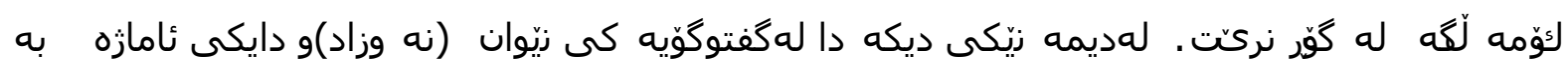

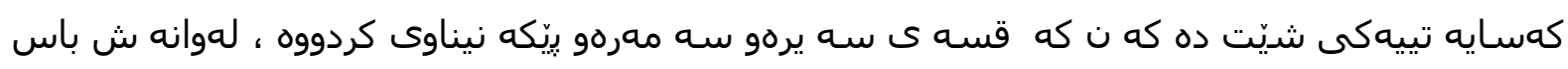

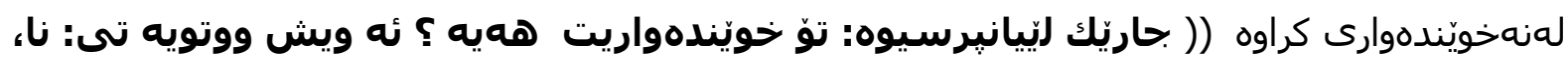

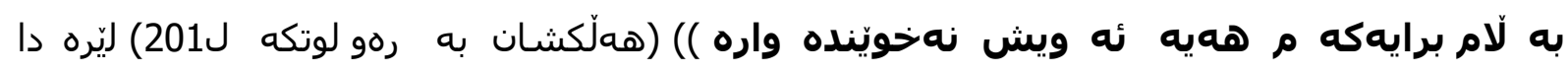

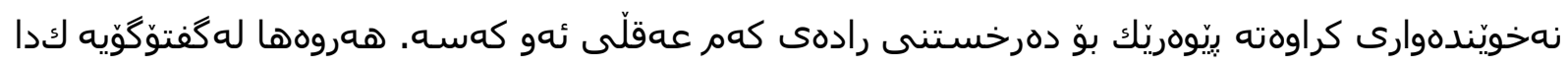

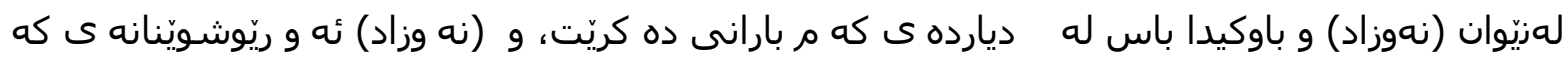

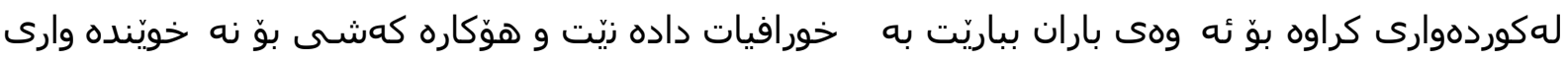

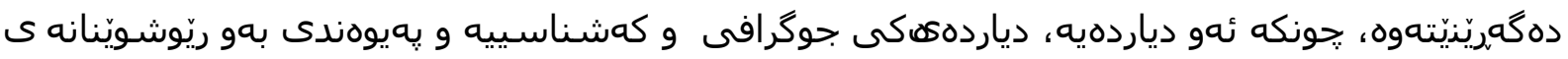


وهكو (بووكه بهبارانه..تاد) ييه كه ئه نجام دهدريت ( ـ ـ ـه وه كَت له سايه ى نهخوينده وارى !بووه

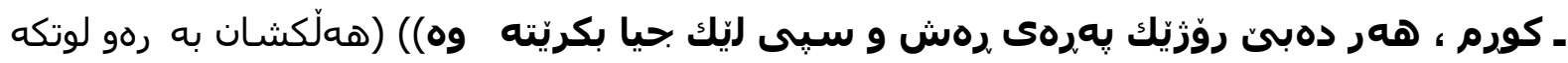

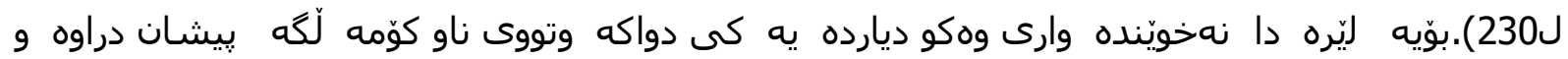

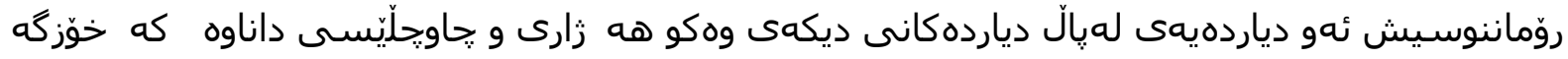
بهنهمانيان دهخوازريّت.

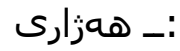

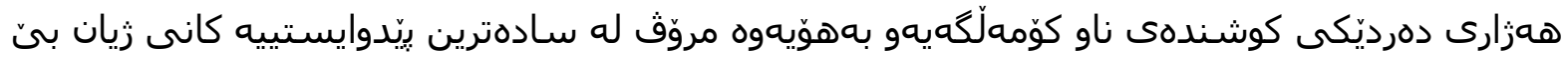

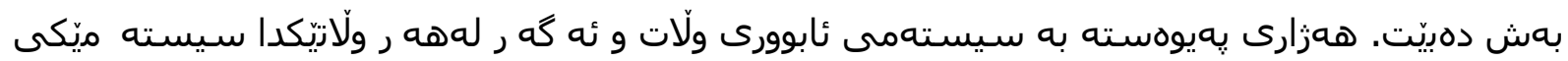

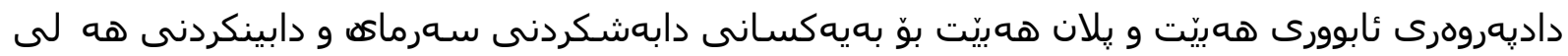

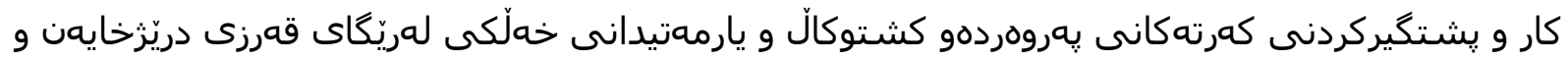

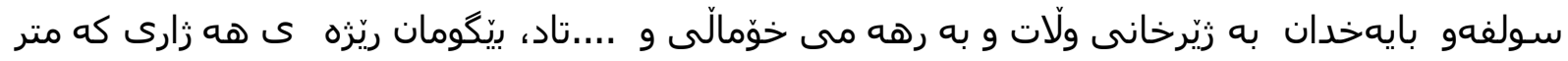

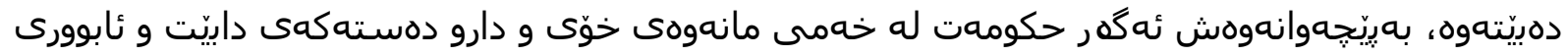

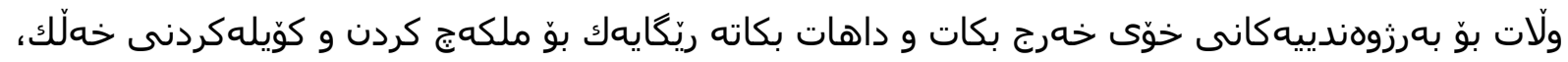

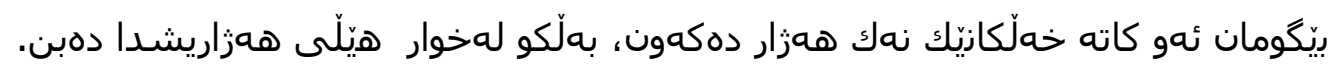

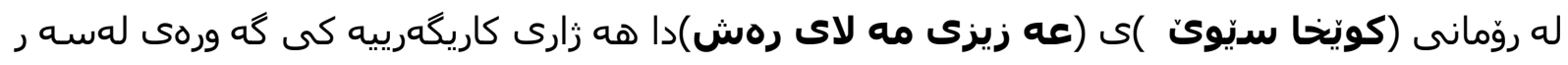

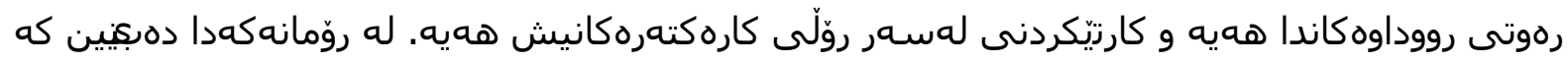

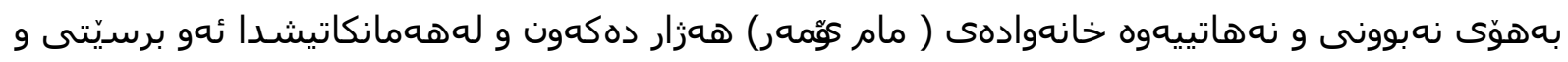

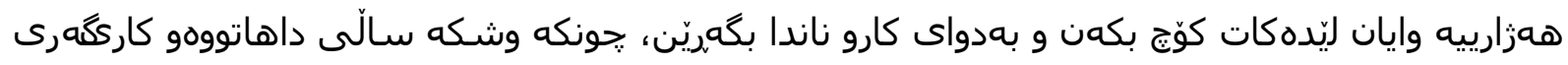

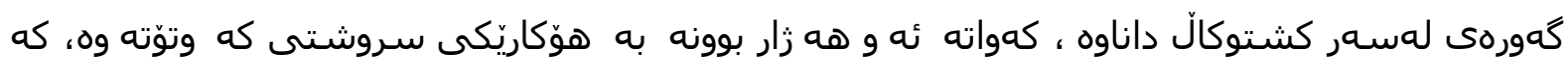

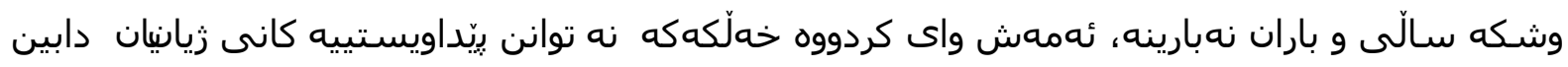

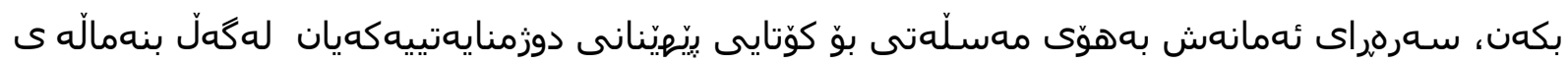

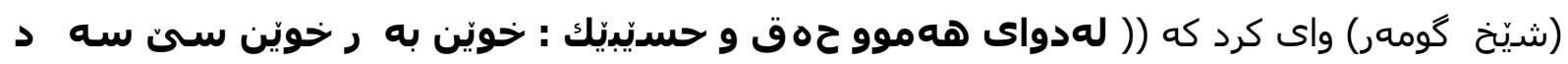

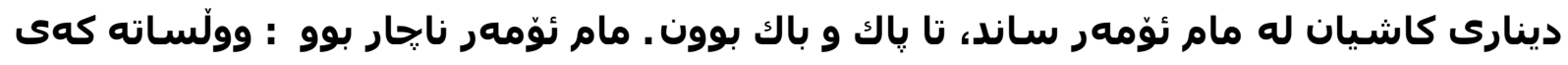

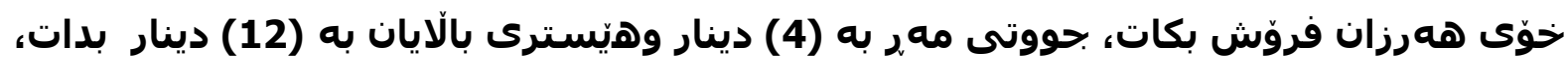

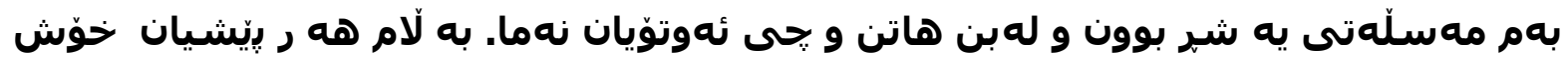

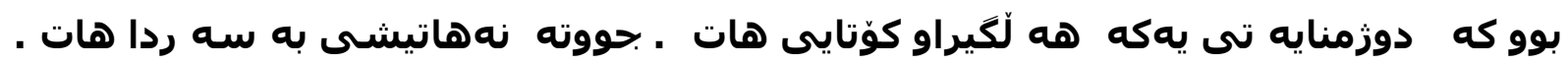

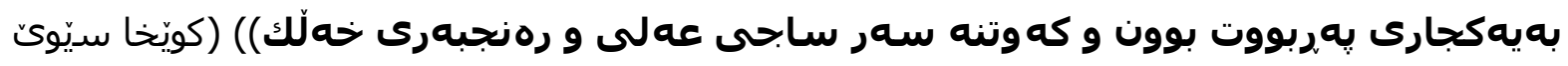

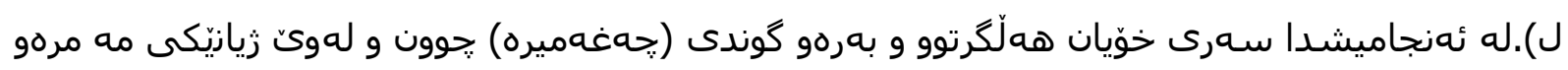

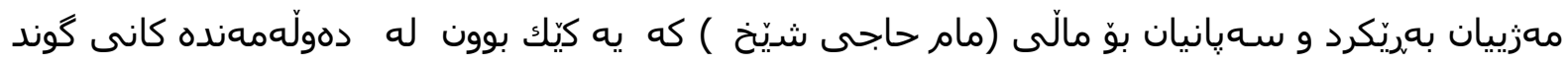

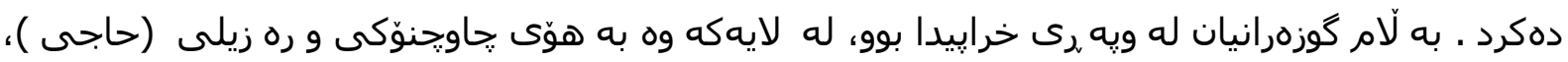


لهلايه كى ديكهشه وه به هوّى نه خوّش كه وتنى (مام ئوّمه ر)و لهجيّكاكه وتنى، روّماننوس به وردى

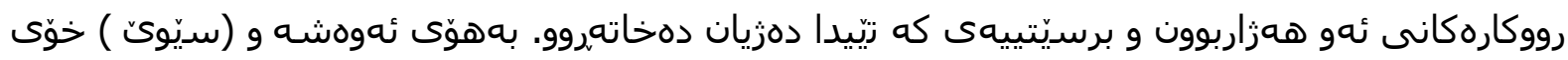

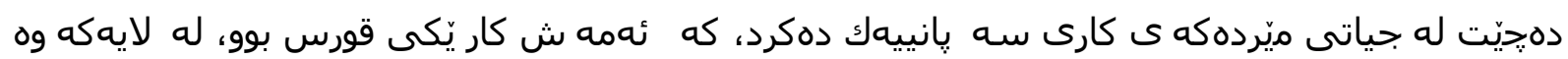

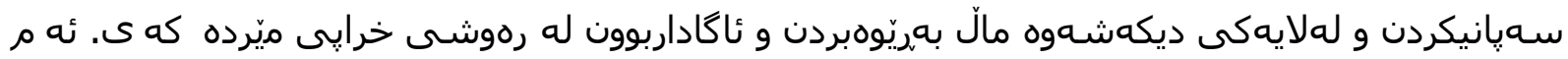

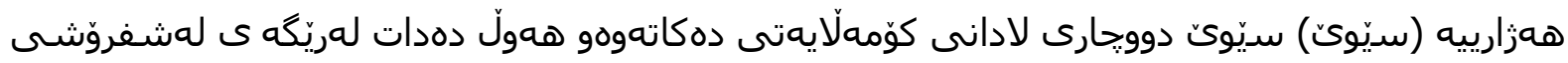

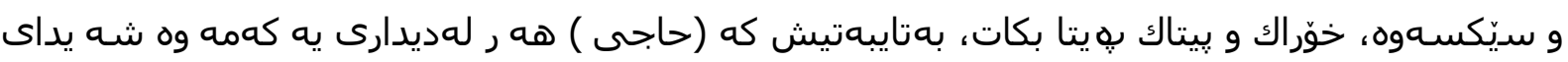

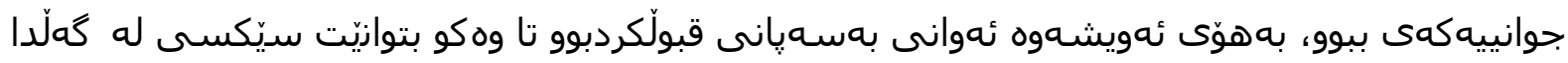

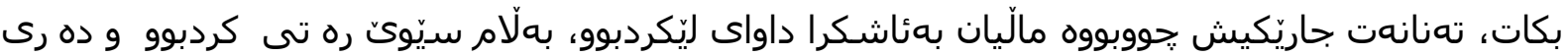

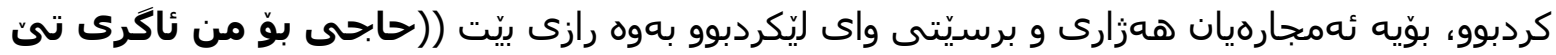

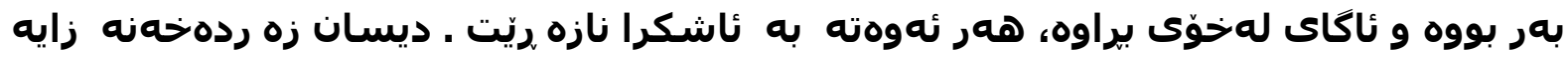

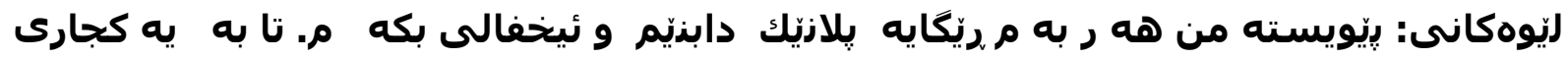

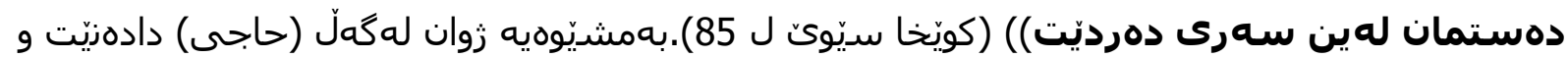

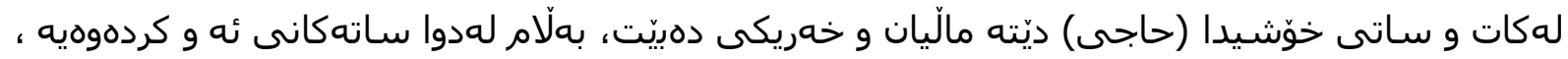

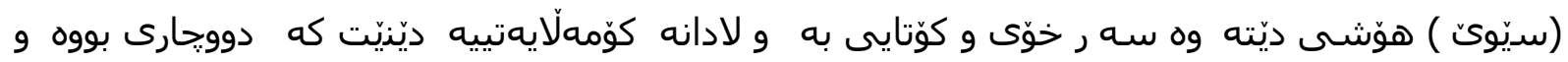

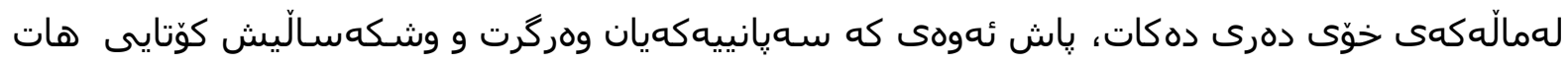

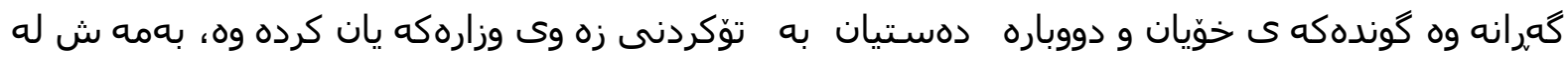

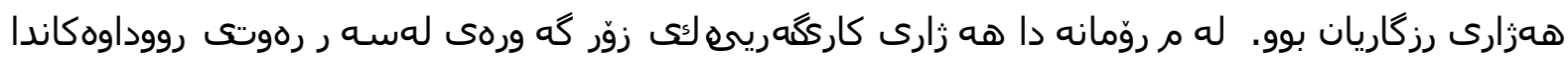

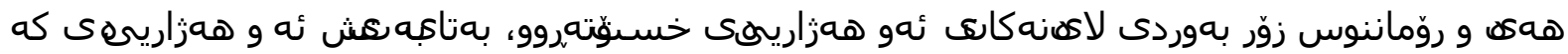

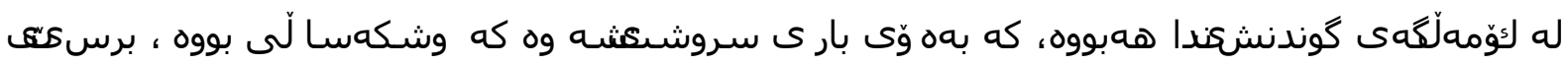

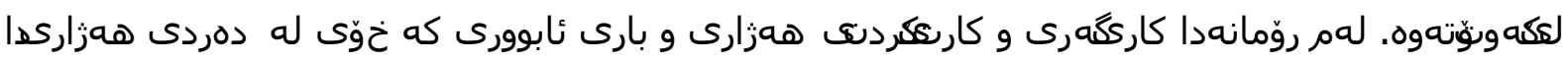

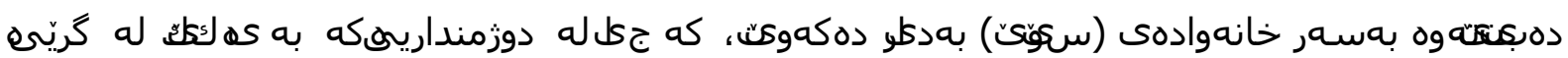

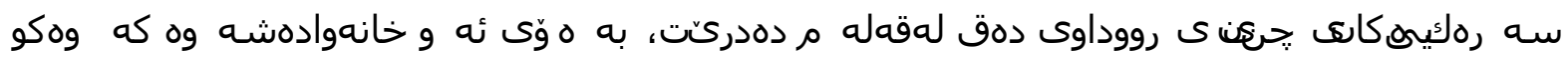

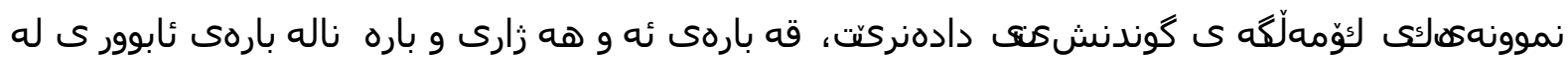

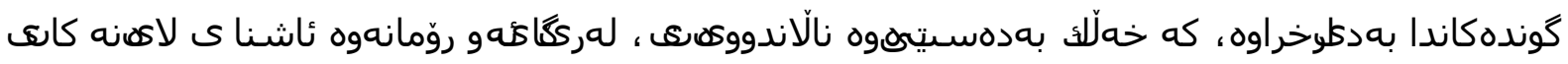

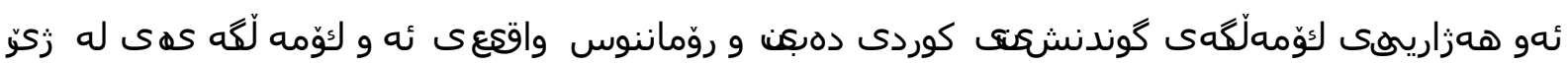

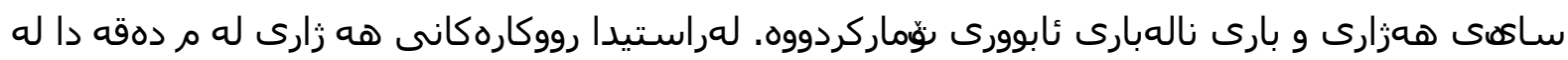

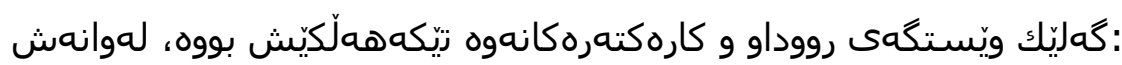

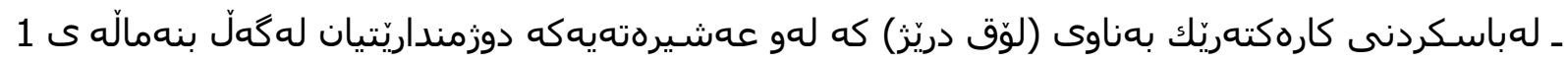

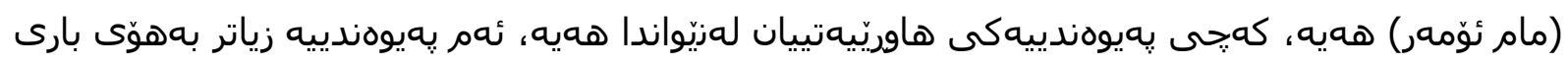

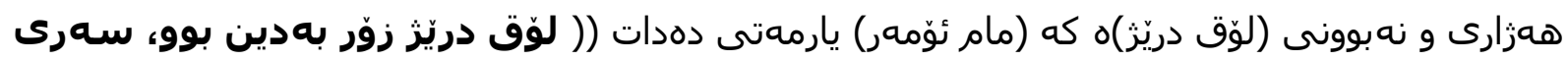

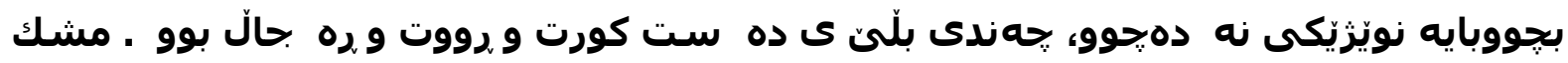

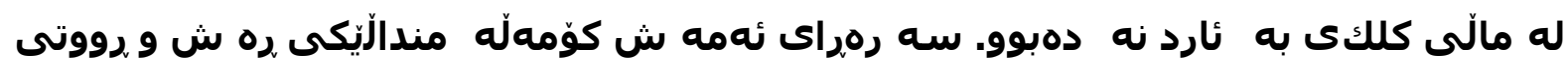

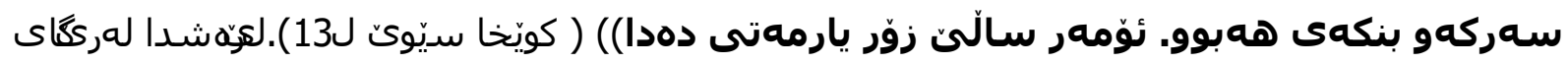

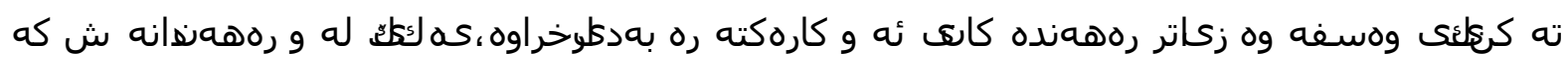

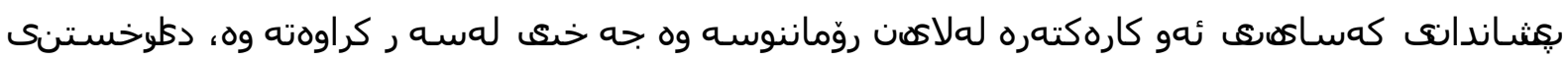

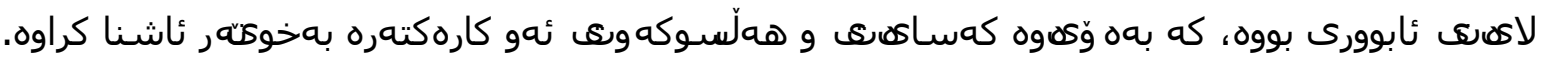


ـ له كِيرانهوهى ريانى ههزارى و نهبوونى مالّى باوكى (سيّوكَ) كه بههوّى نهبوونييه وه هه ولّيان داوه 2

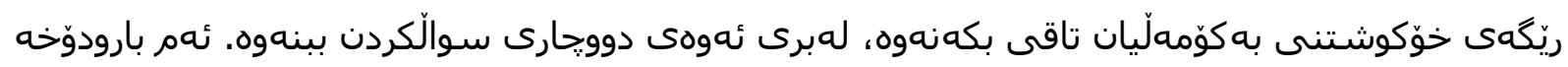

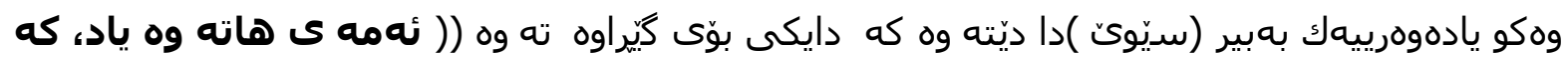

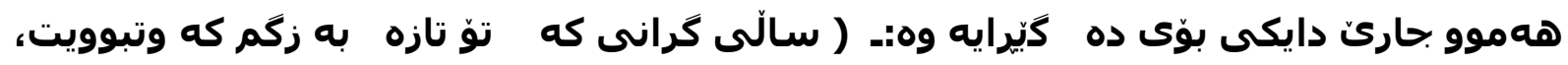

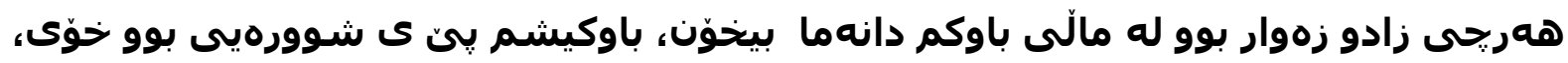

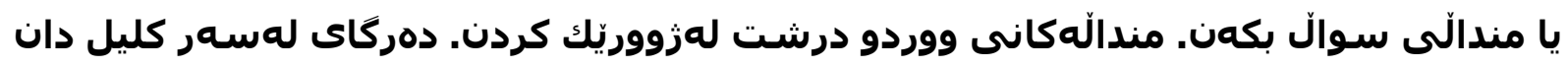

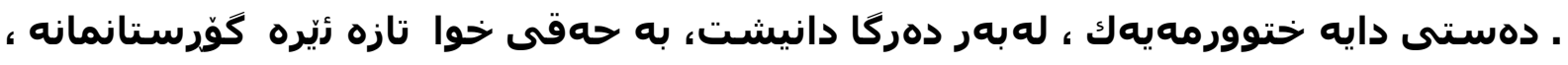

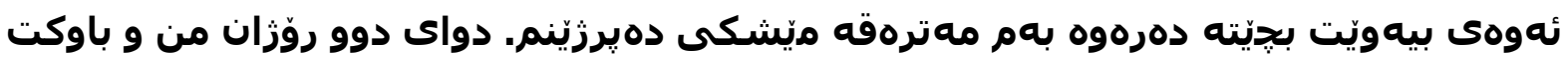

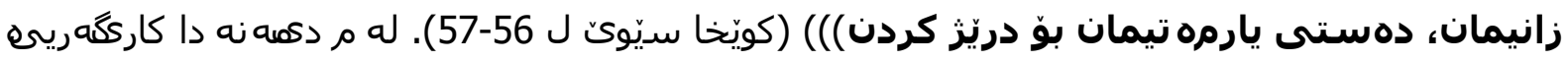

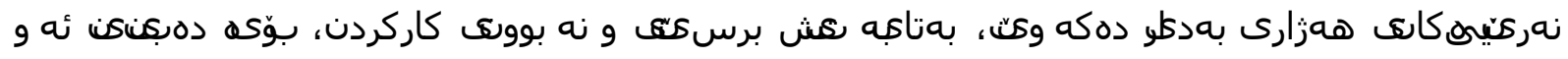

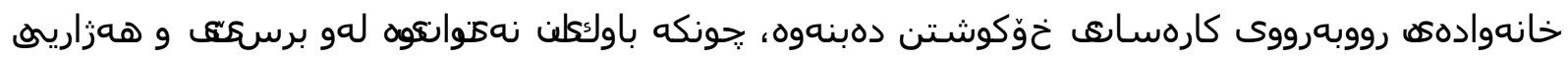

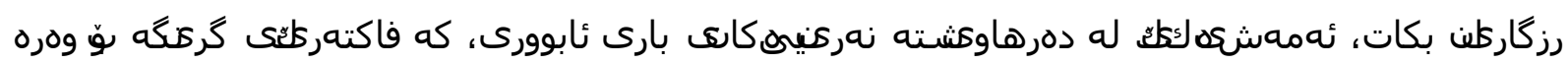

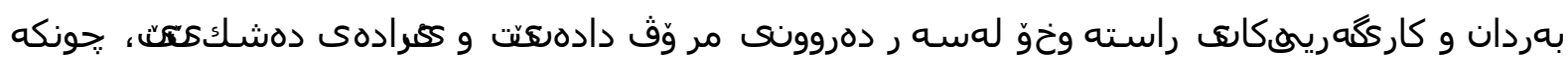

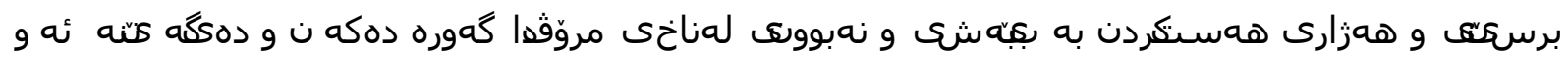

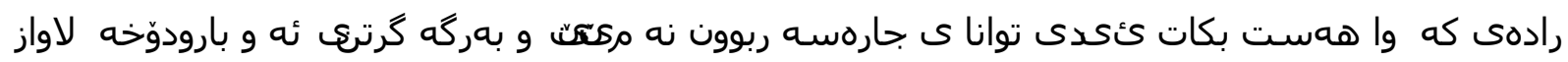
دهبs

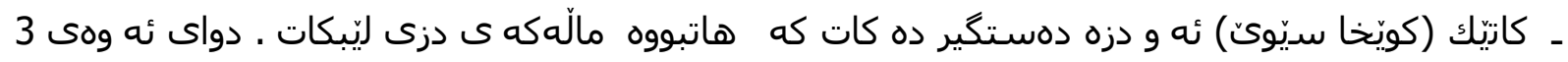

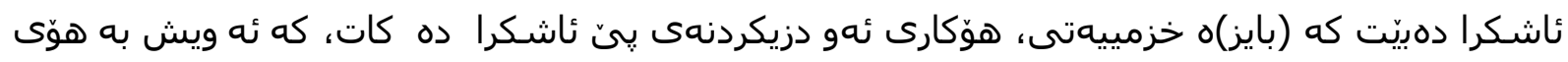

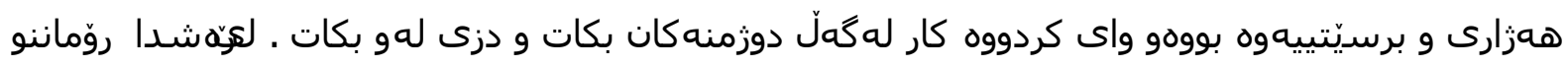

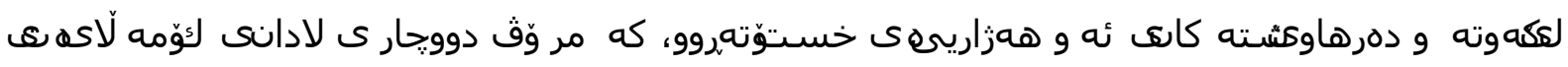

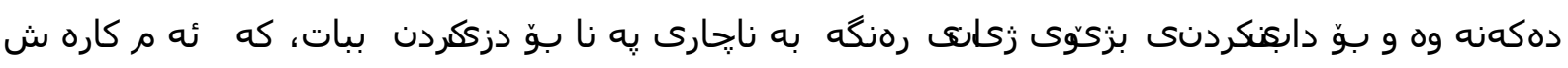

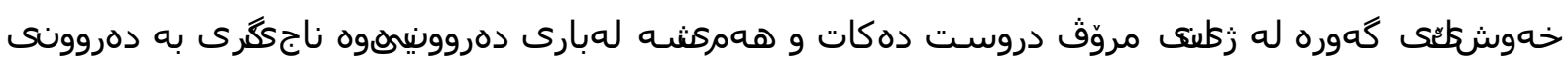

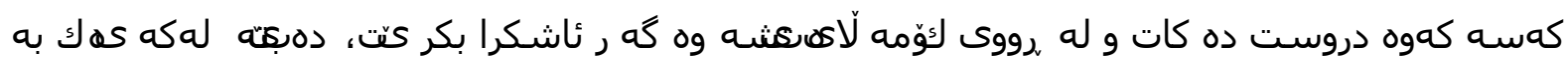

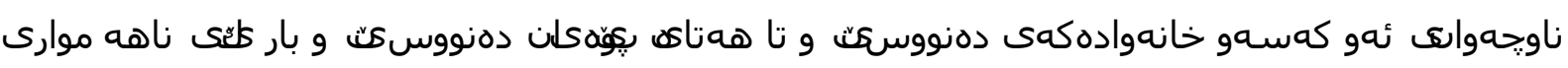

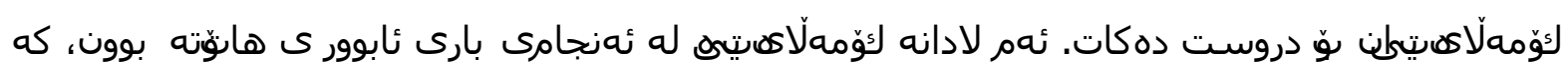

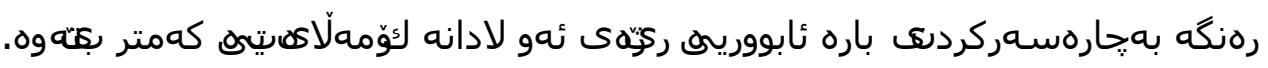

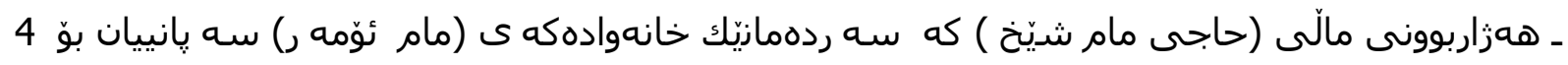

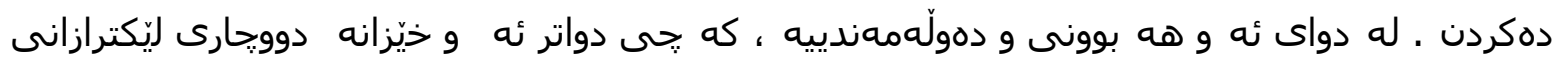

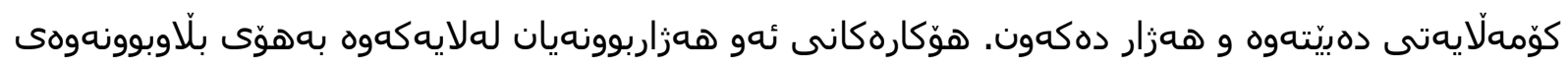

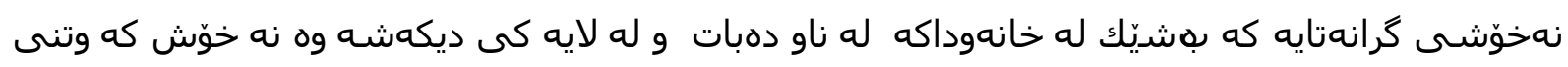

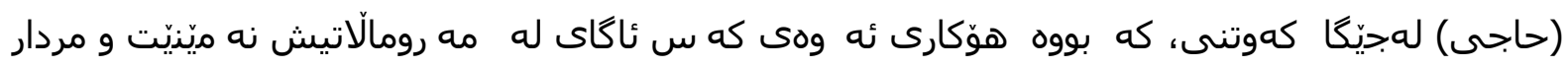

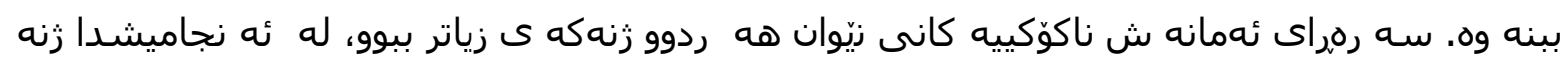

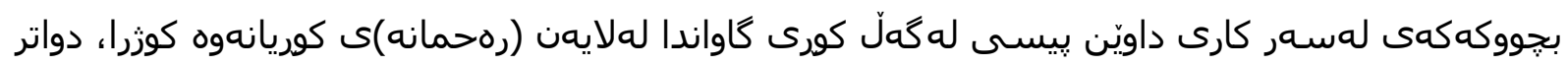

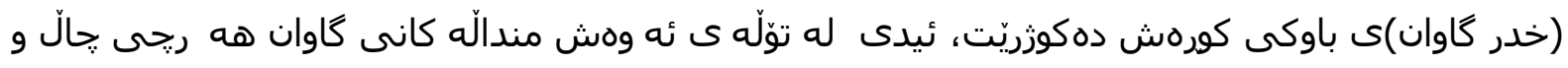

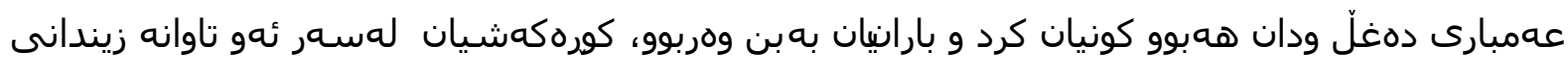


كرا. (( رِيّش حوكم دانهى ترساين، رووحمان هاتبووه سه رى لووتمان كه له قناره بدريّيت،

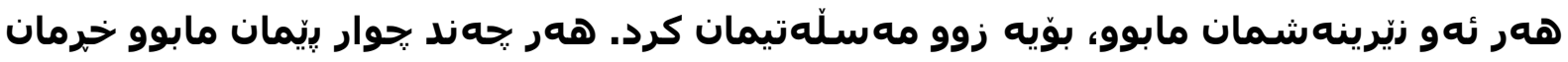

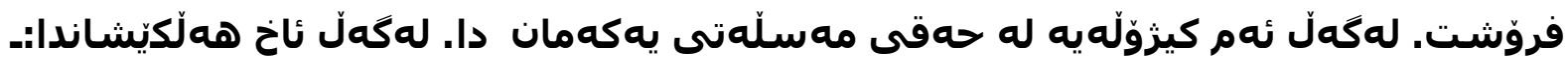

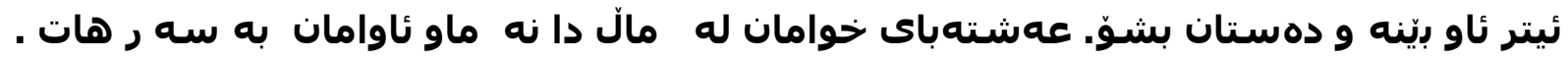

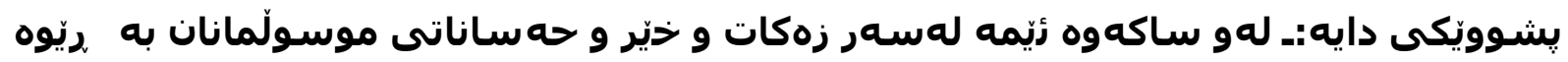

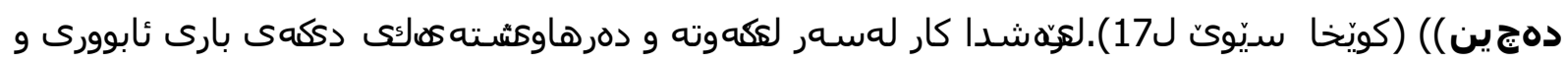

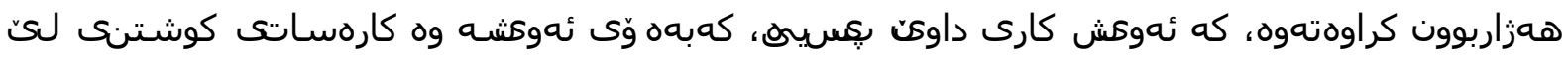

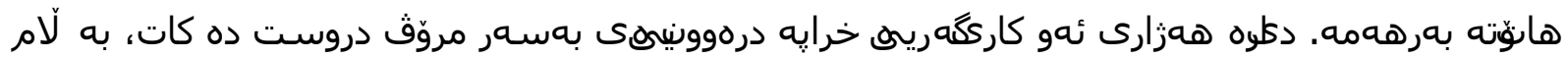

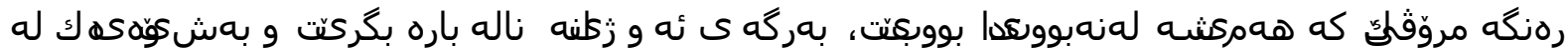

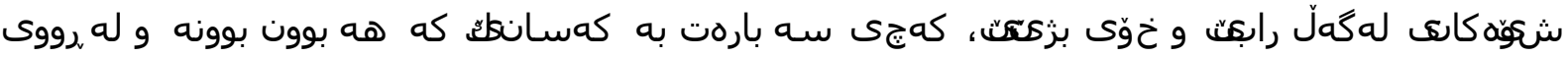

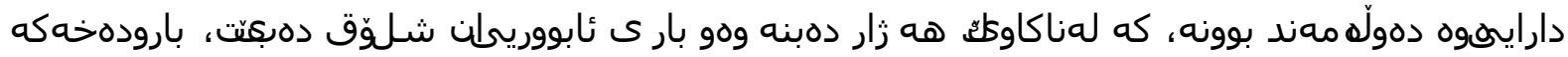

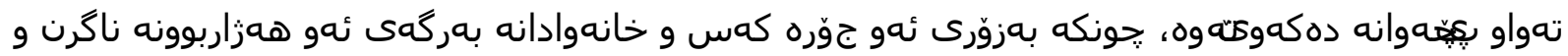

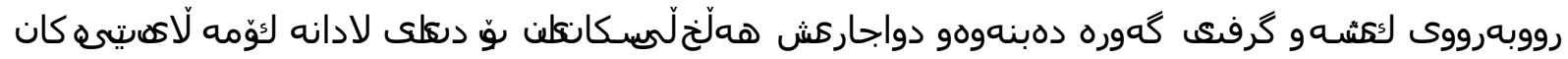

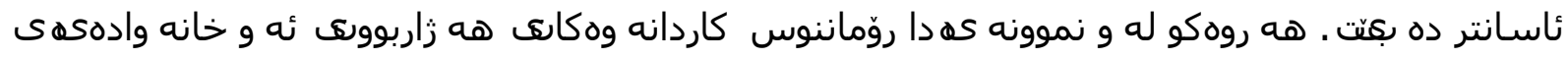

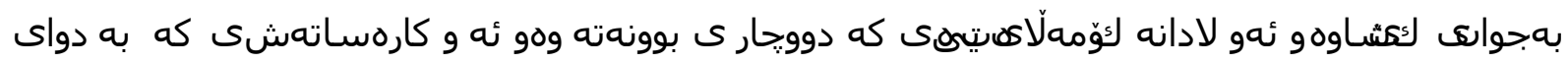
خوَّكا ه كناوه نوّمارككردووها

لهروّمانى (شار)ى (حوسيّن عارف)دا ههزارى يانتاييهى فراوانى له ناو ده قدا گرتووه و روّماننوس

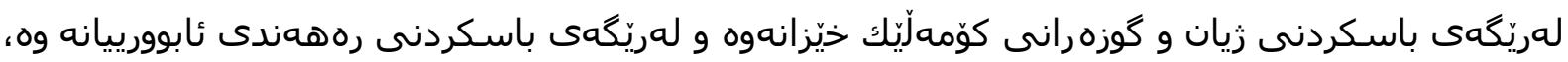

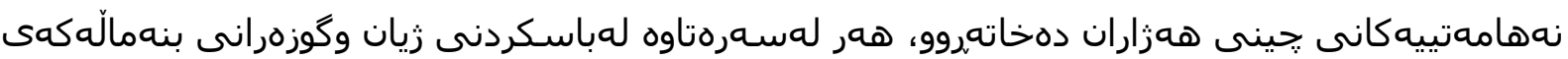
(سابير) دهخاتهروو و ئاستى ههزارى و نهبوونى و دهستكورتييان ديار دهخات، بهتايبه تيش كاتئك له ناو ناو

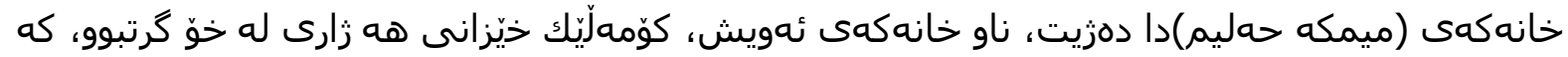

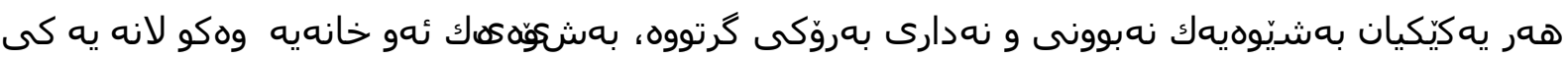

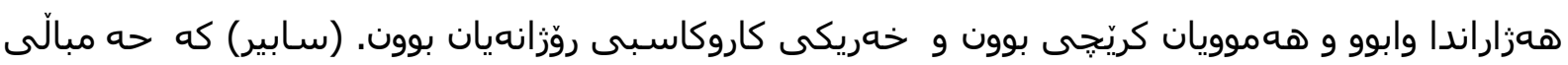

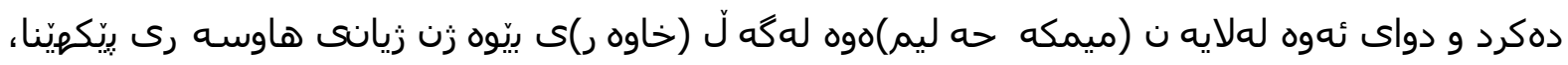

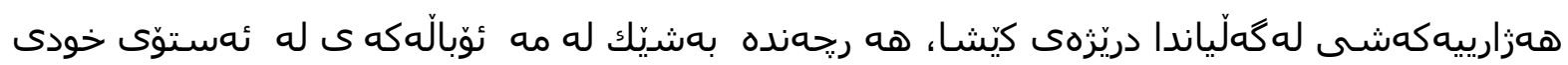

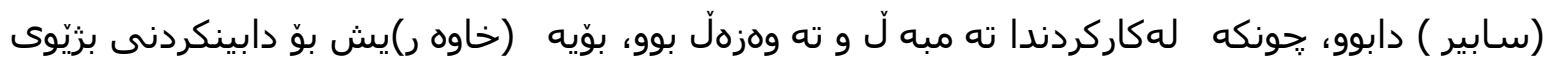

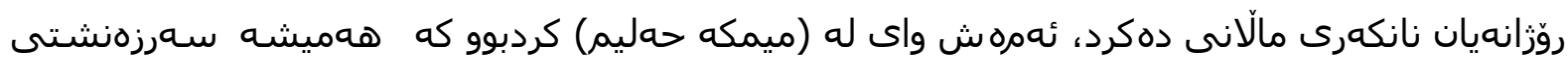

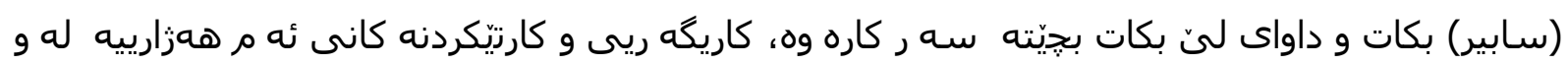

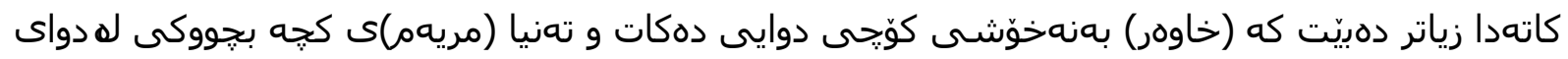

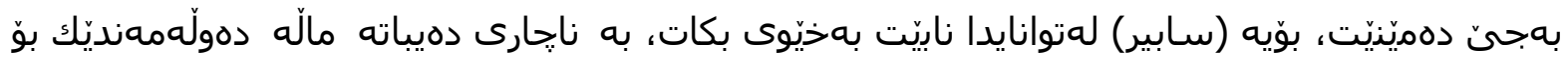

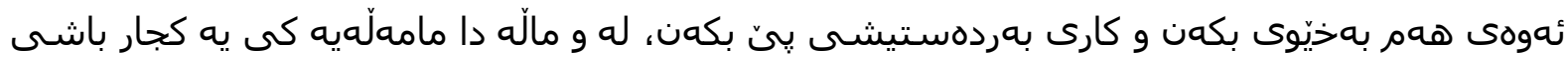

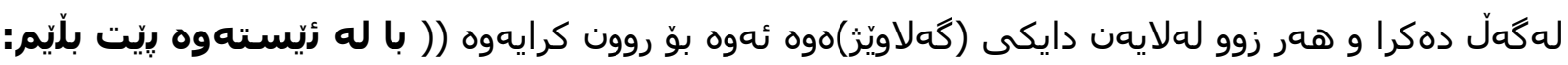

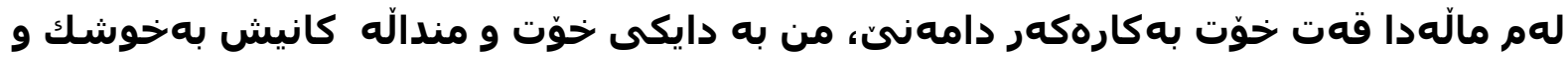

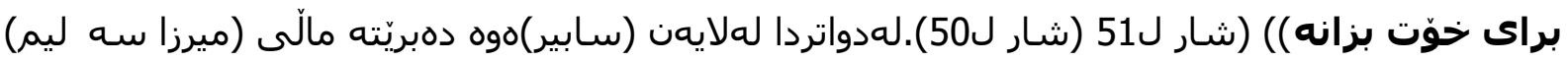

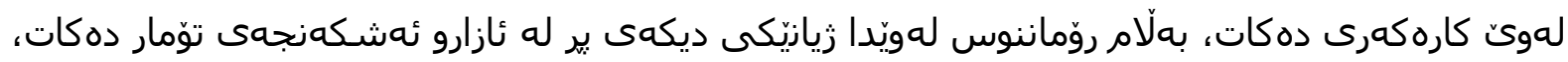

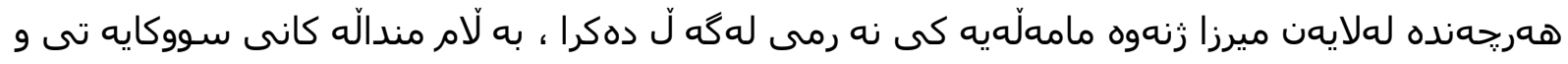


ئازارى جهستهييان دهدا و وهكو مروّوّيك سهيريان نهدكرد، ئهمش بووه هوّكارى ئه وهى له و مالّه دهر

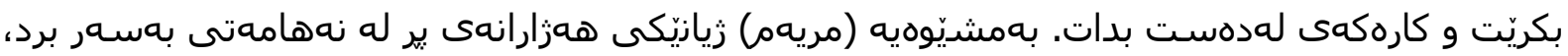

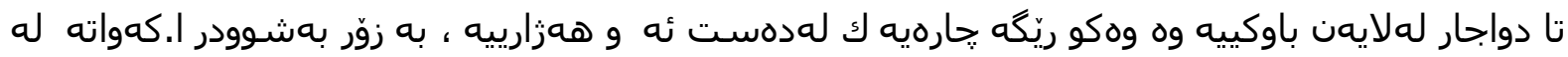

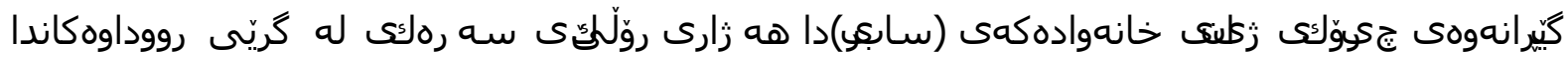

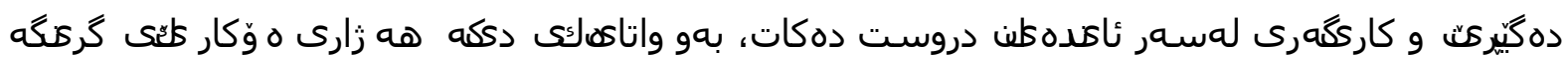

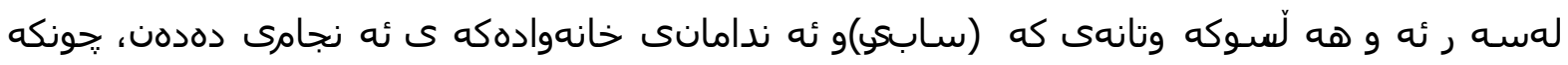

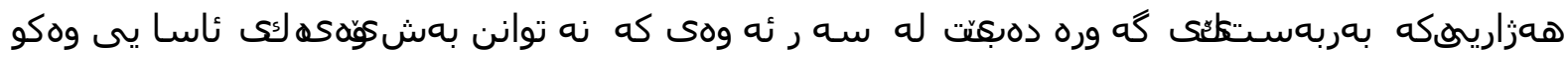

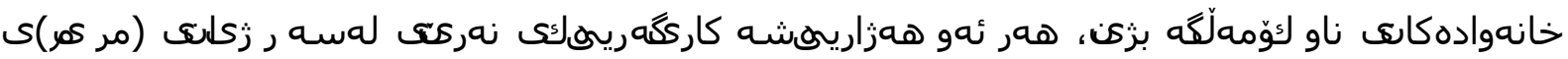

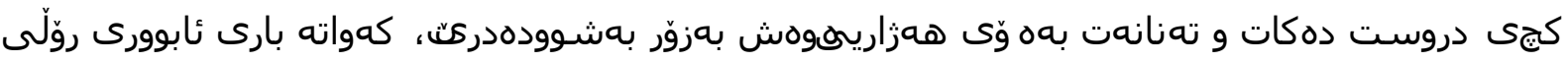

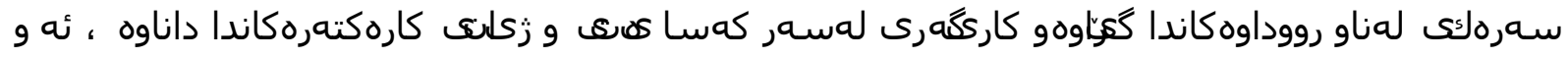

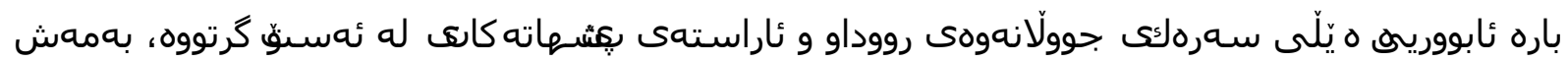

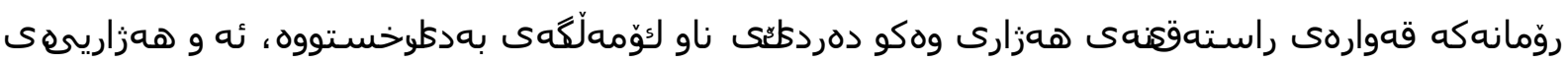

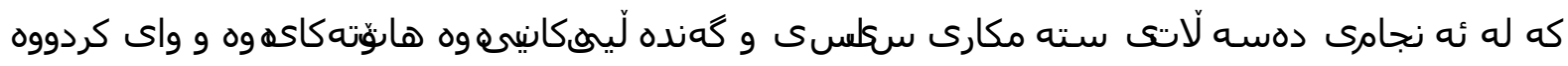

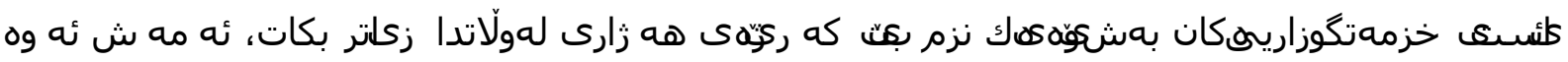

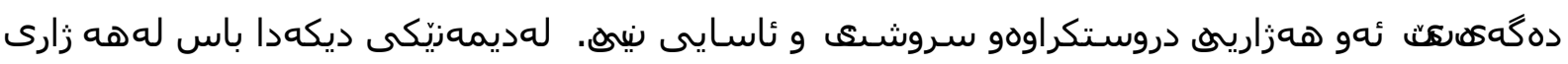
و دهستكورتى (ئهورهحمان)ى كارهكتهر دهلكريت كه بههوى نهبوونييهوه يهناى بوّ كريّكارى قور بردووه

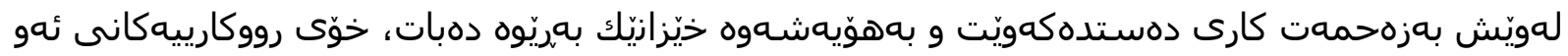

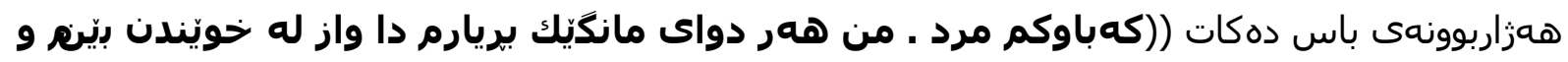

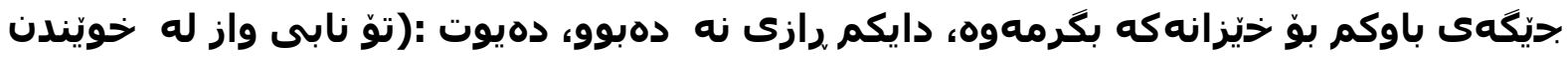

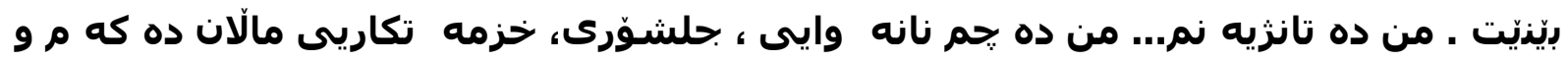

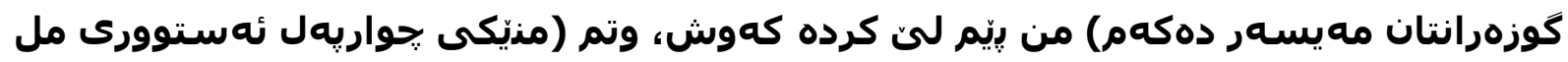

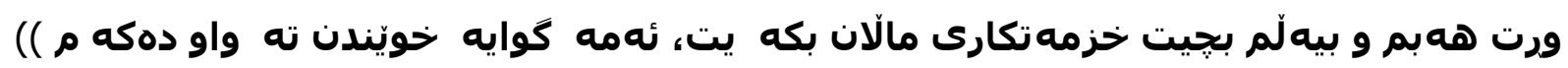

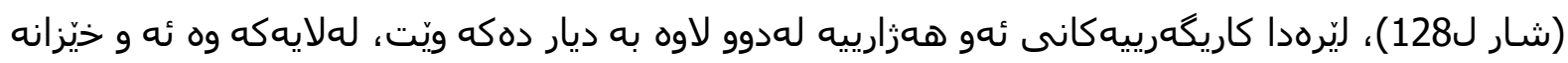

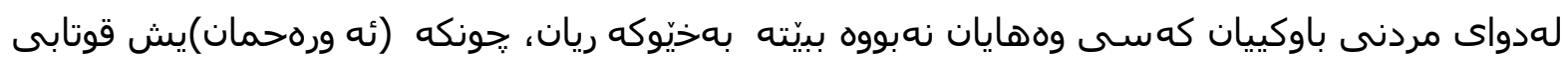

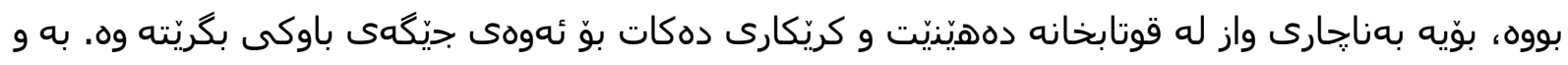

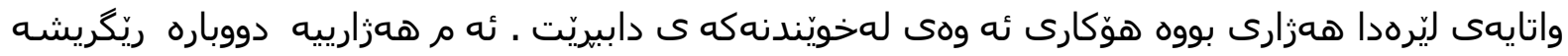

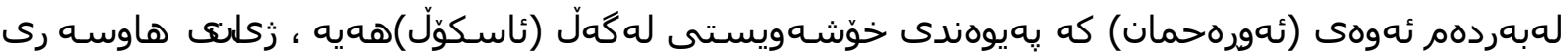

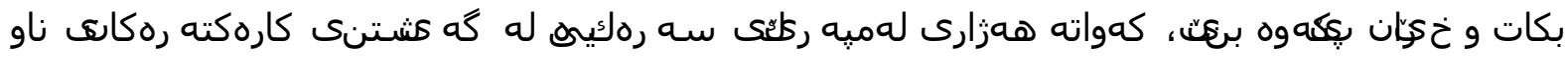

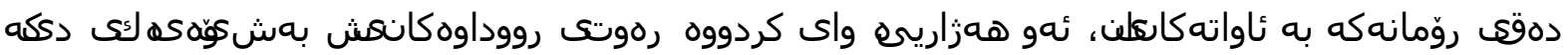

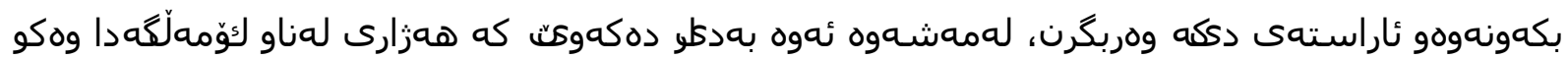

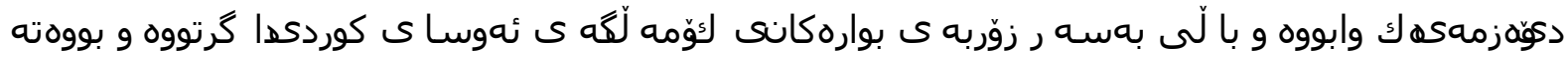

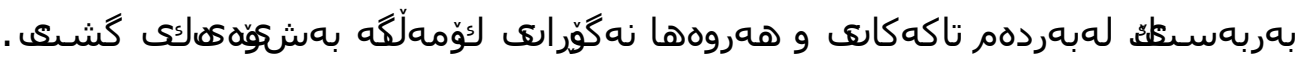

لهلايهكى ديكهوه روّماننوس يَنجهى لهسهر كيُشهيهكى كهوره داناوه كه لهو سه ردهمهدا هه بووهو تا

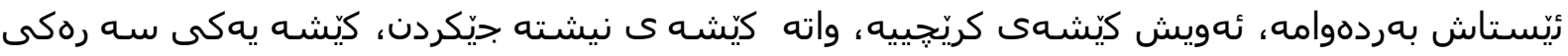

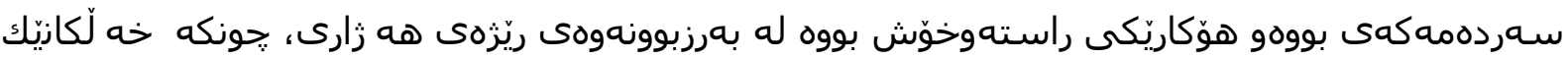

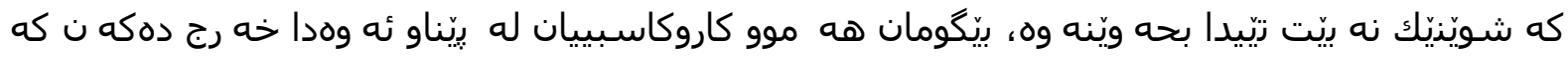


شـويْيَك بوّ حهوانهى خيّزانهكانيان دابين بكه ن، ئهمه ش كاريكهرييه كى ته واو لهسه ر بارى دارا يى و ئابوورييان دادهزيت، بوّيه روّماننوس له خستنه رووى كيشه ى نيشته جيَبوونهوه لهلايهكه وه رووناكايى

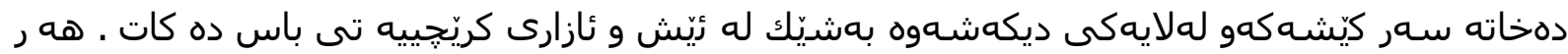

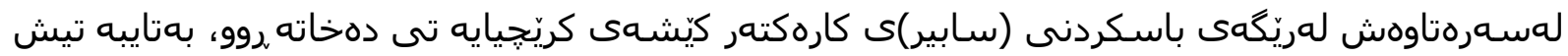

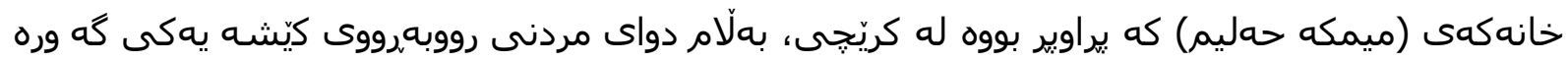
بوونهوه، بهلام خانووهكه بووه مولّكى ميرى و دواتريش ميرى خستييه سه به ر ناوى كابرايه كه وه وه كههاته

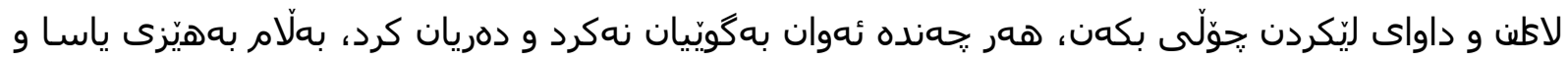

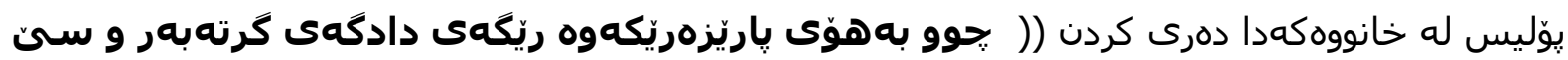

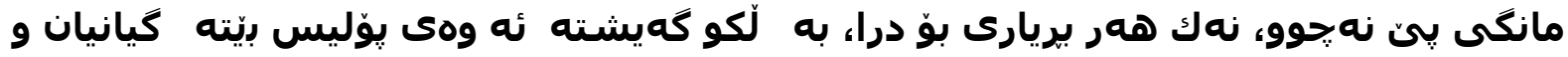

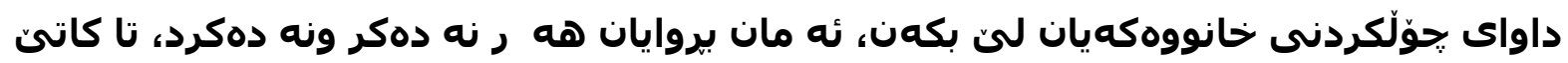

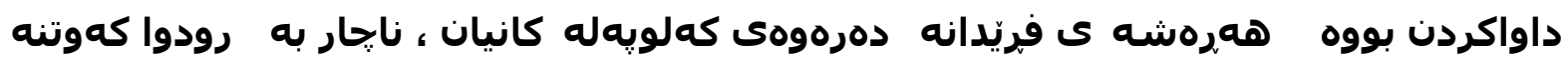

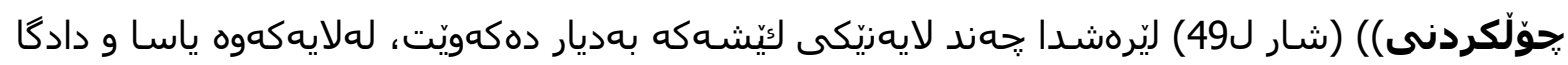

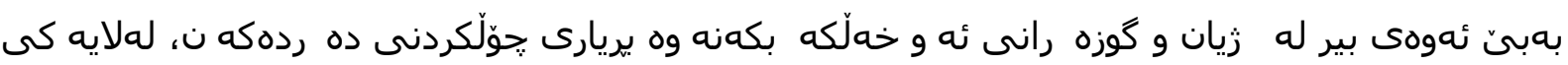

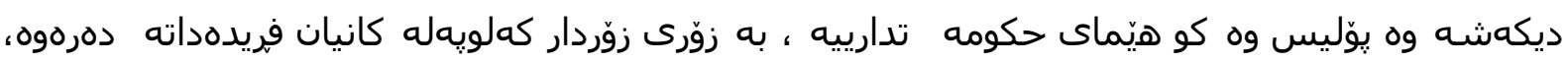

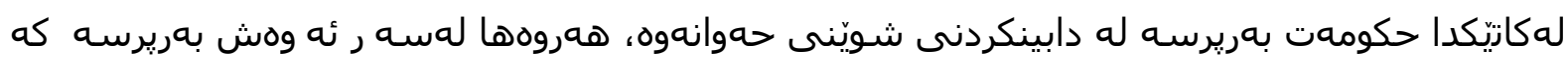

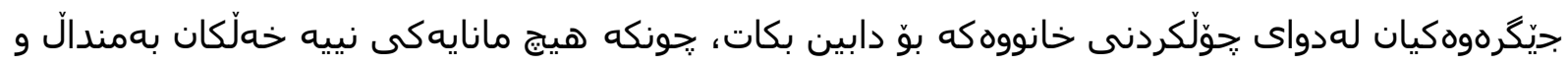

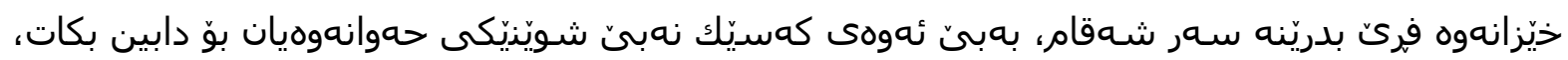

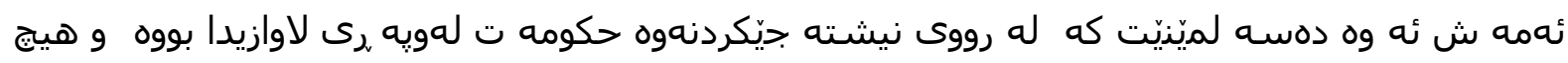
يروّزهيهكى نيشتهجيَكردنى راستهقينه بوّ ههزارهكانى لا نه بووه. له دواى ئه مر درهكردنه ش (سابير )ى

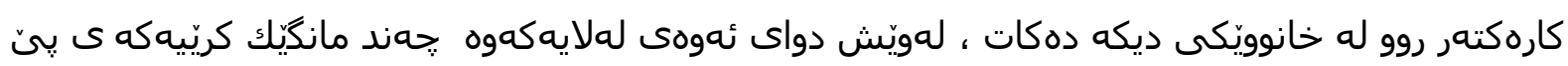

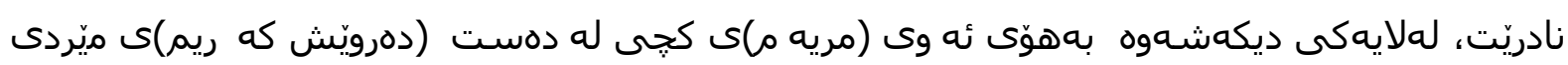

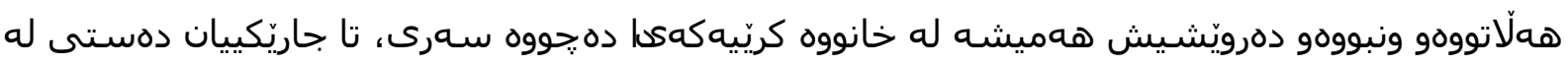

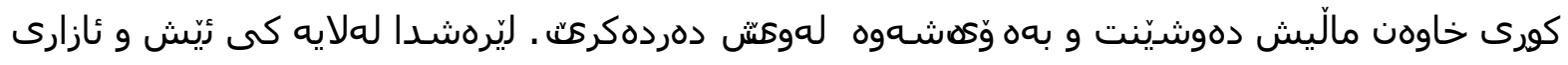

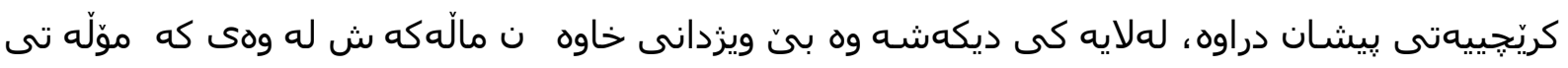

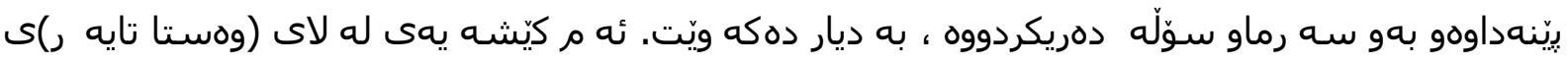

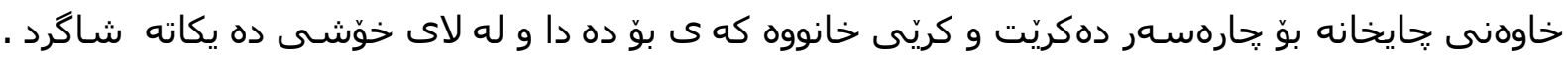

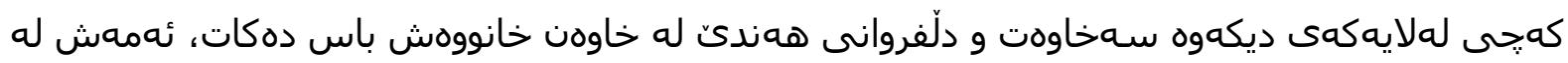

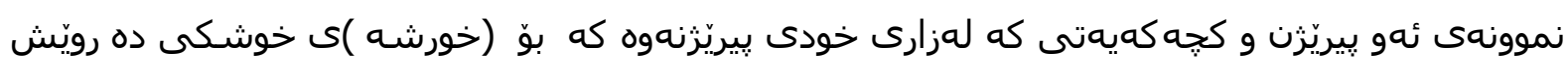

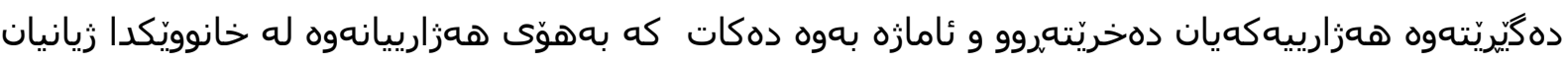

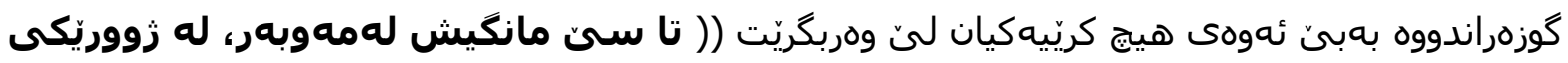
كوّنه خانوويهكدا ده رياين، ماوه ى رِينج سال بور خاوه

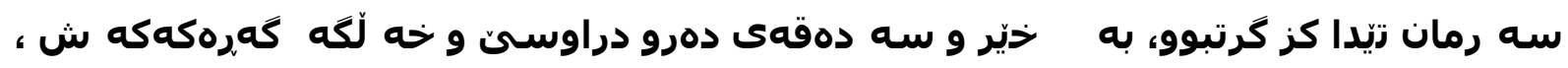

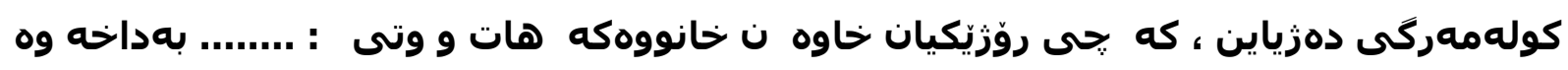

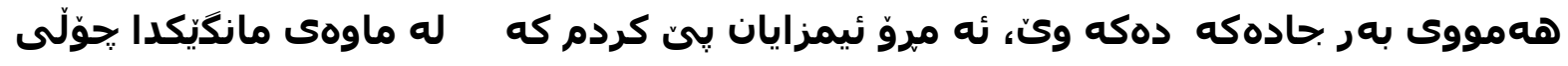

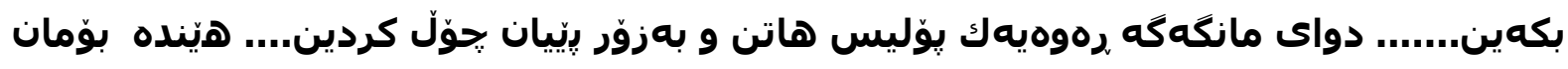

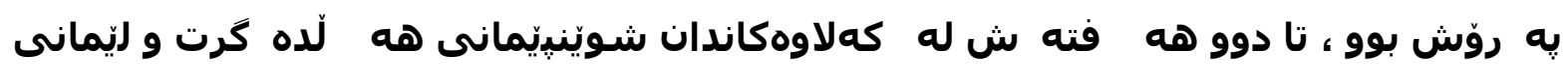


دهيرسييه وه ، هيّنده ى بوّى هه لّسوورايه ، خواردنى بوّ ده هيّناين )) (شار ل 98-99).ليّره دا

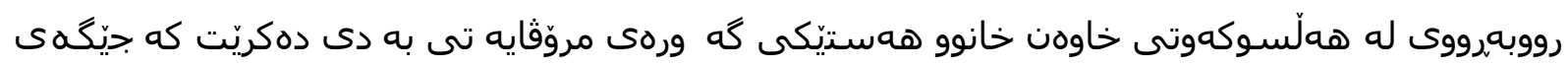

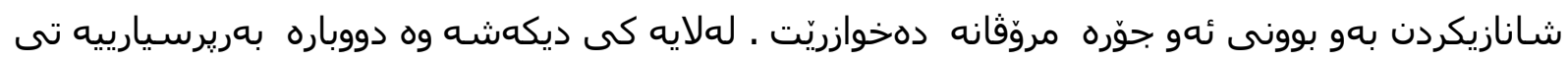

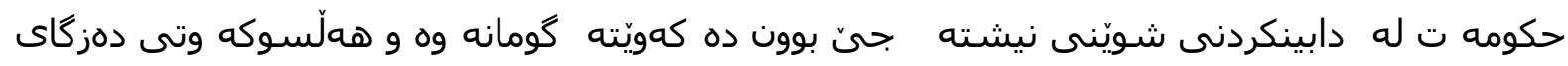

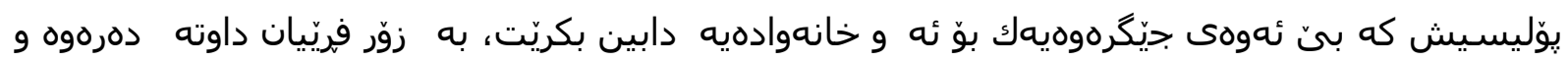

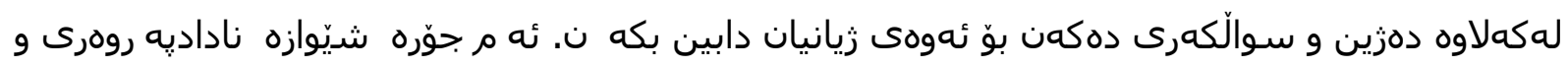

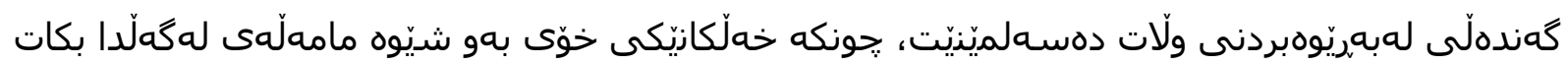

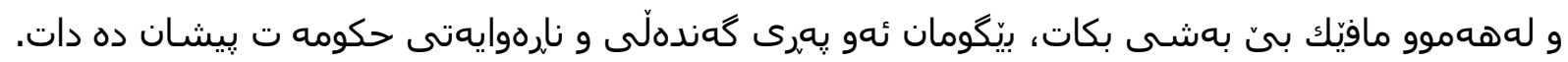

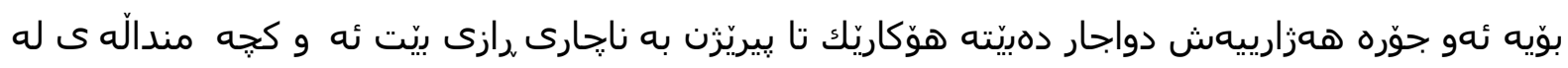

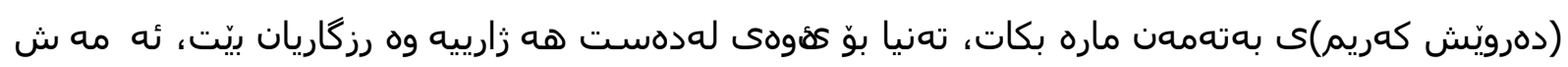

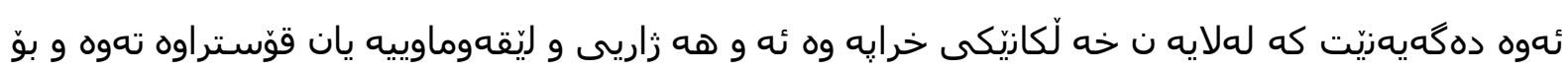
بa رزروهندى تايبهتى خوّيان بهكاريان هينّاوه

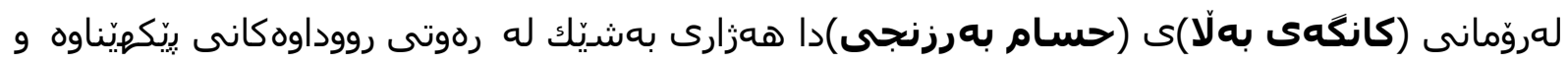

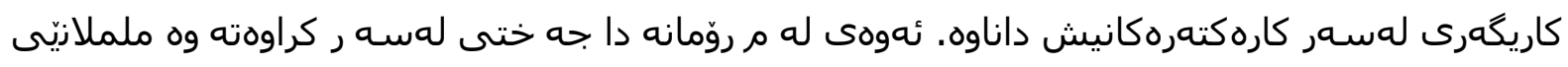

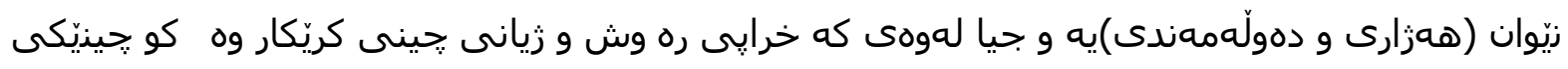

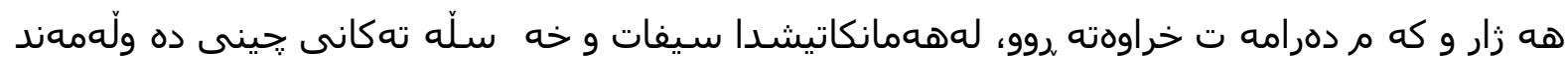

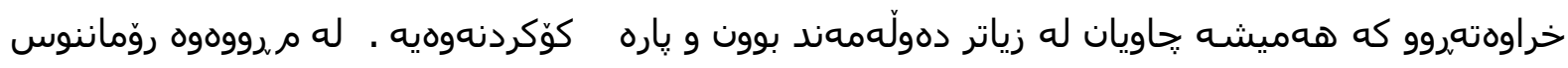

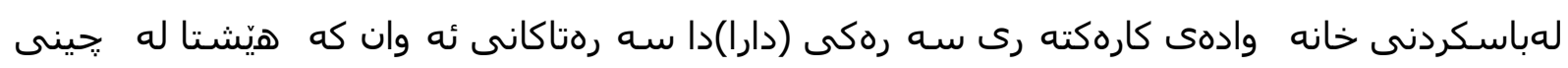

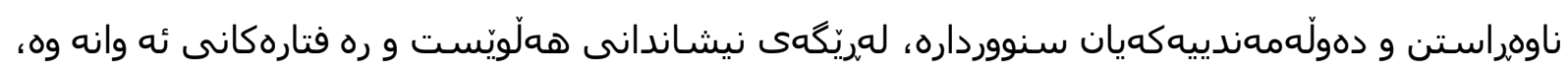

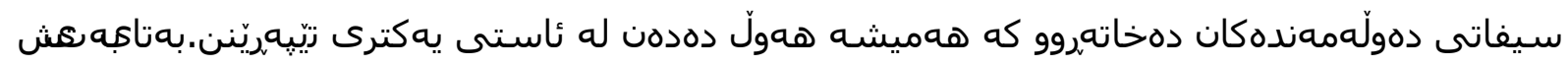

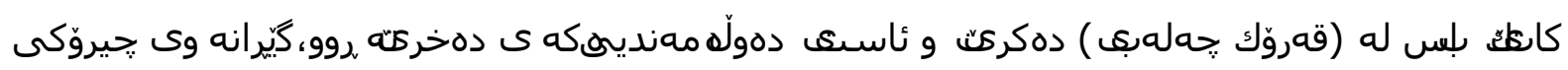

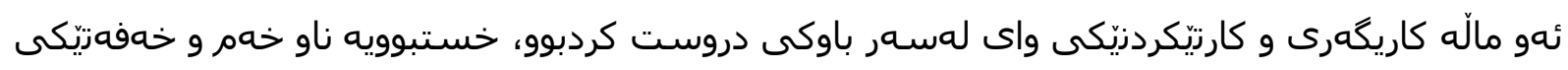

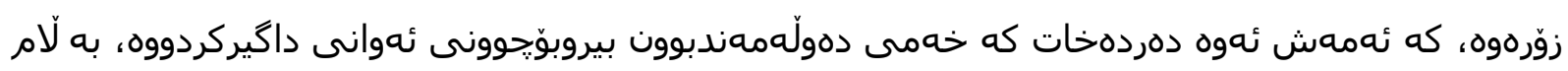

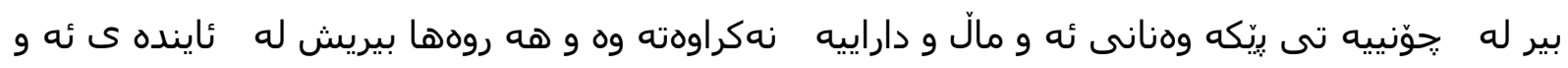

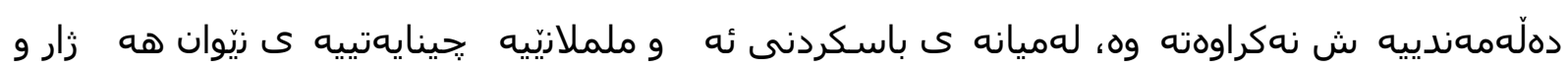

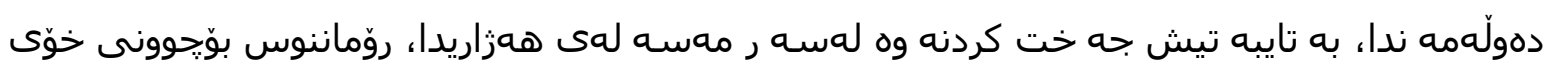

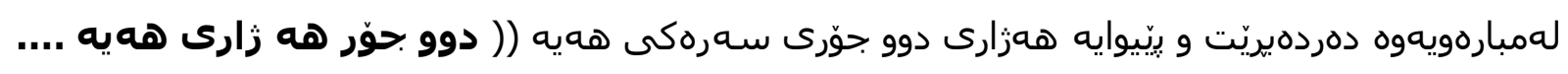

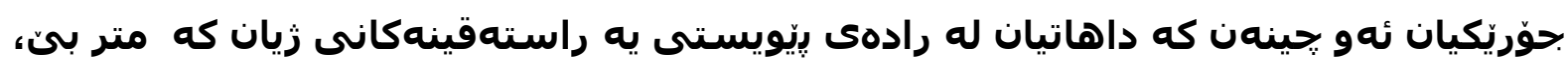

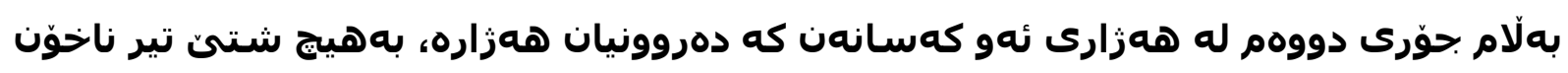

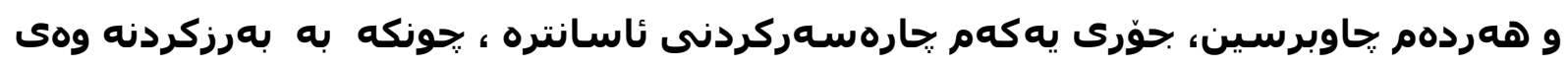

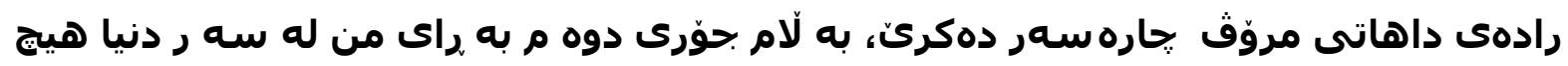

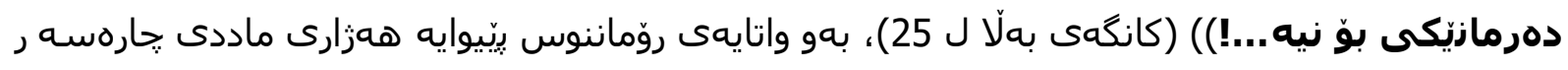

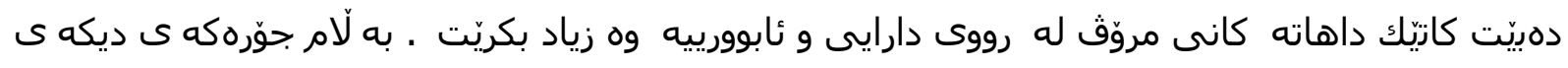

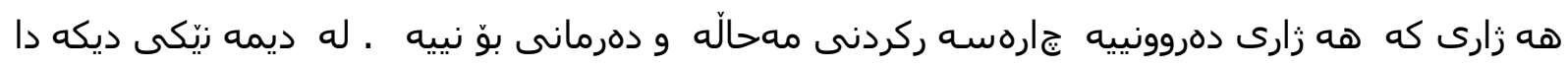

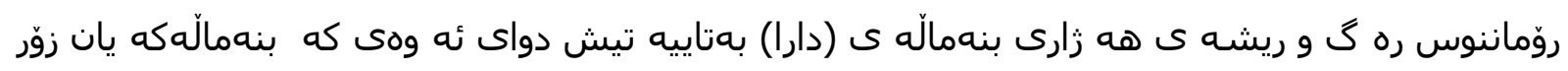

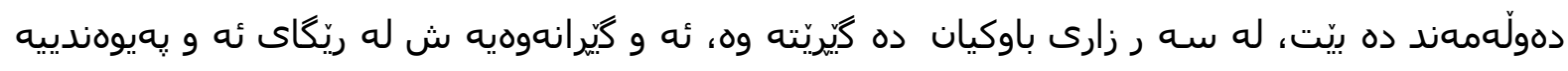


هاوريّيهتييه نادروستهى كه لهُّلّ (بيلال)ى هاوريّى دهبيت (( من و ئهو (بيلال)ه لهمنالّى دا يهكتر

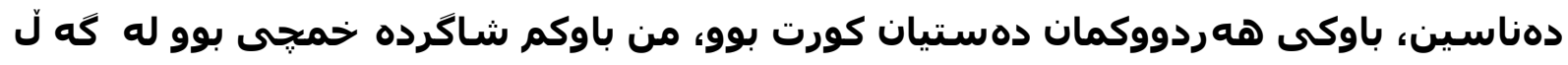

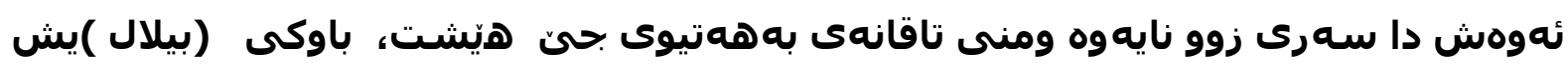

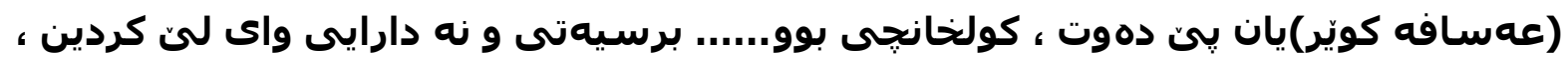

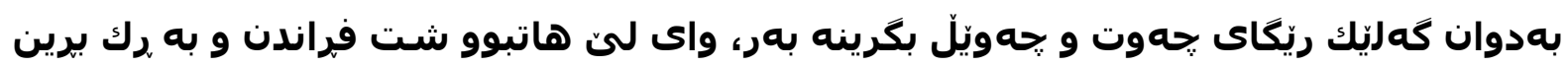

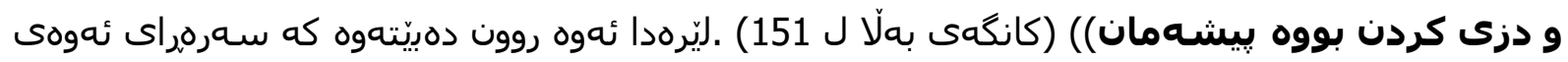

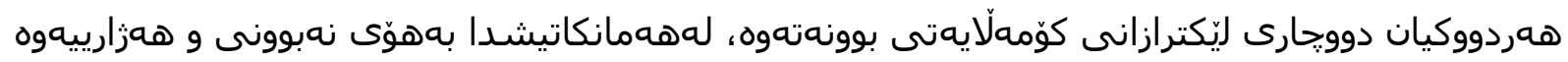

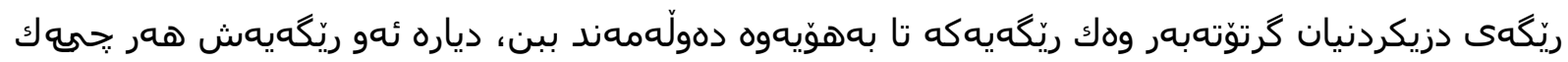

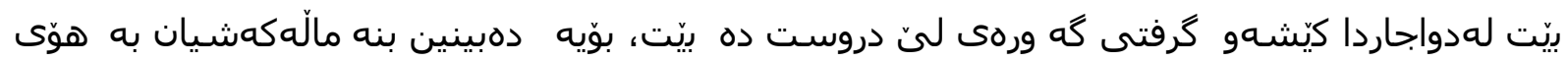

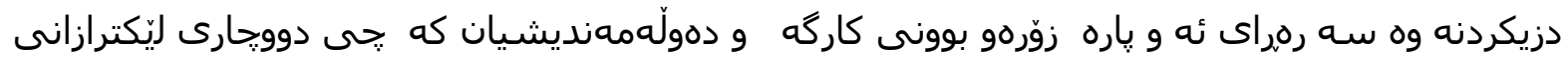

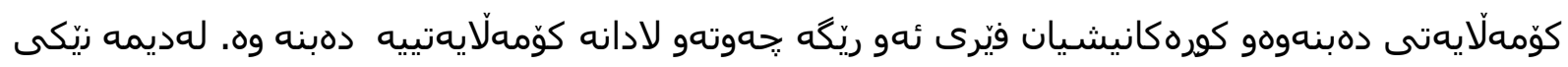

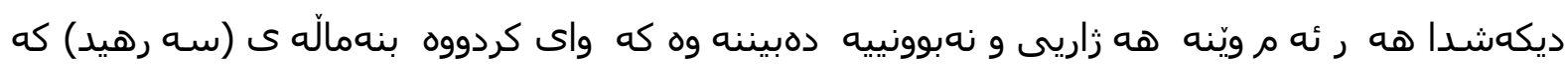

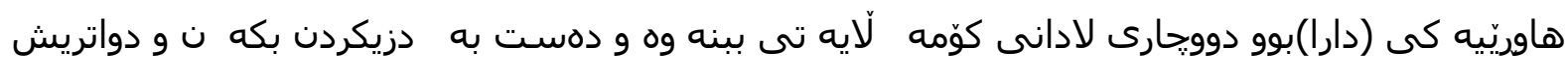

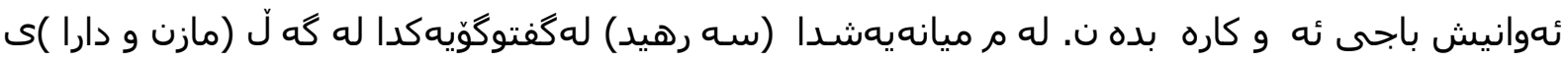

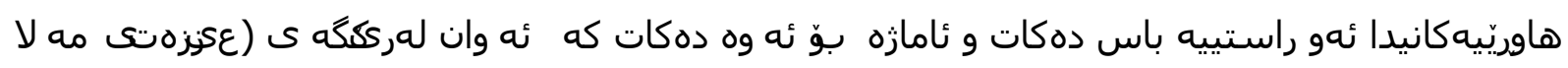

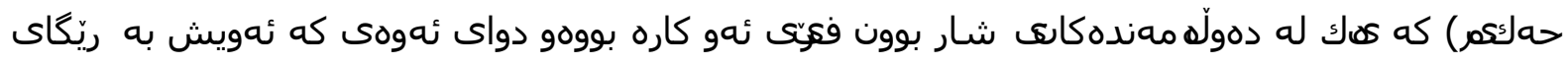

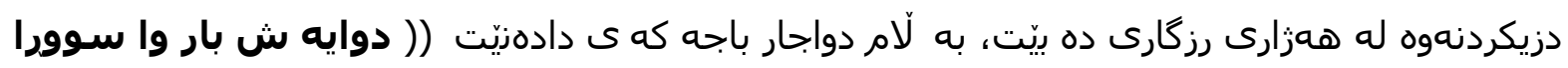

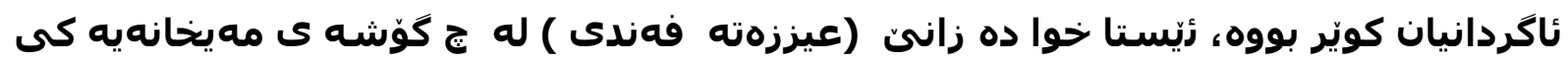

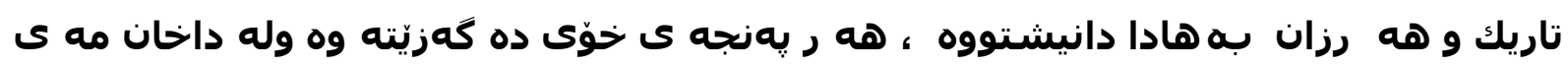

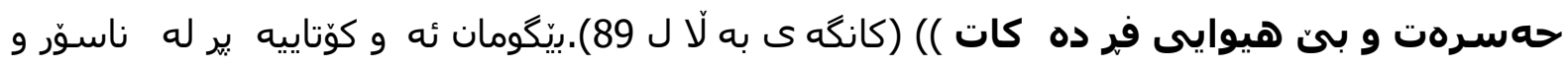

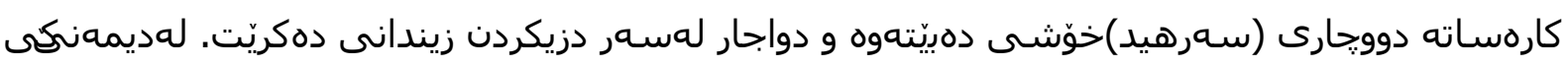

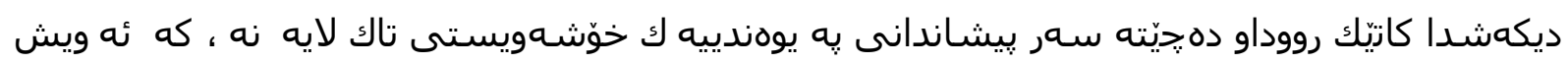

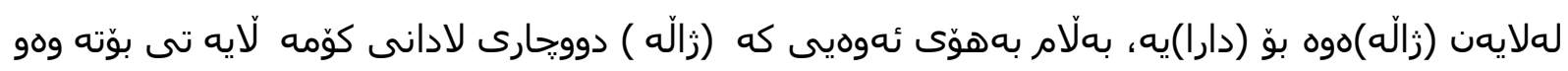

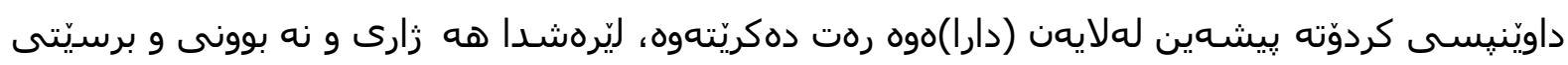

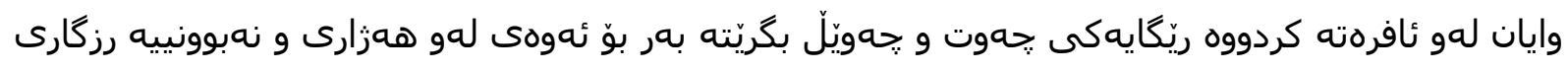

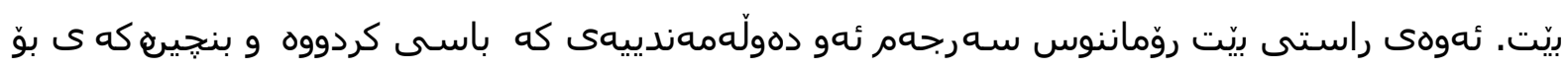

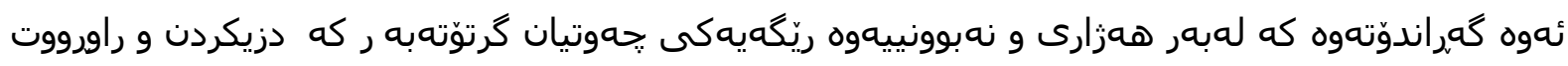

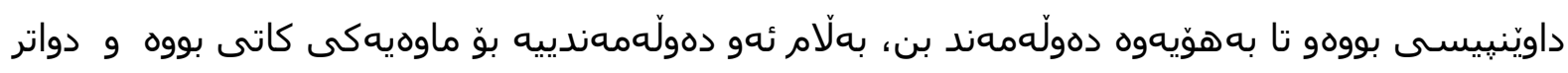

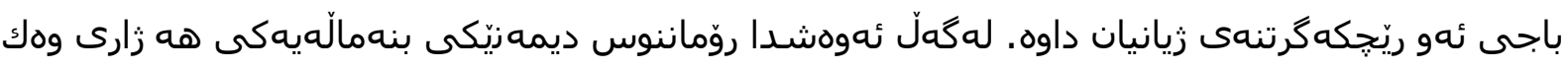

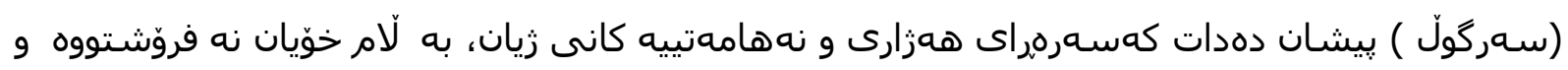

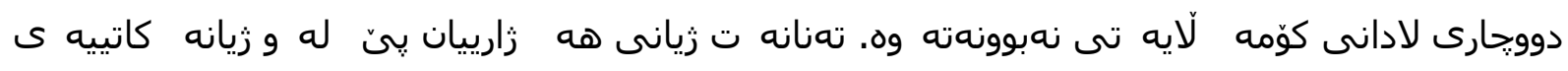

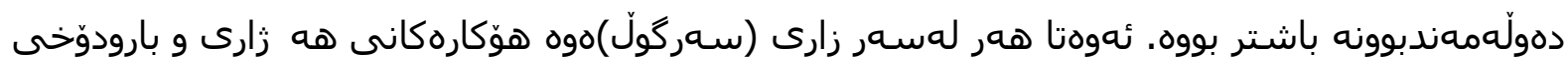

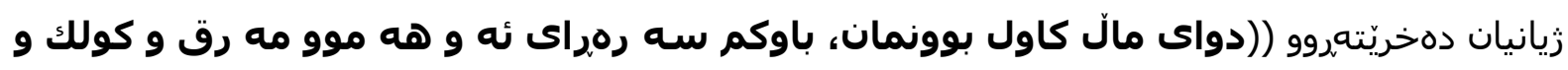

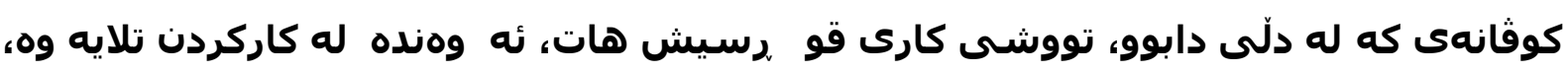

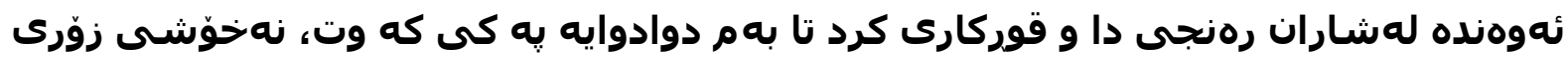

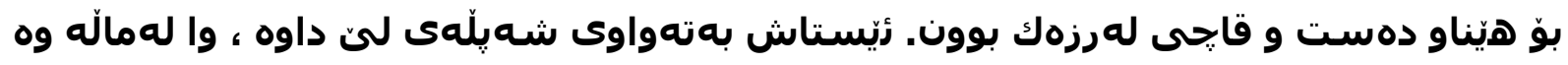


كهوتووه بهدارشهقهش ناتوانى بروا.. ناجار من دهستم بهكاركردن كرد و هاتم له كاركه ى

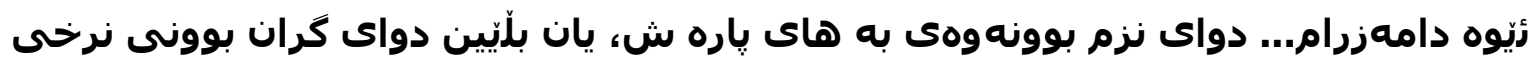

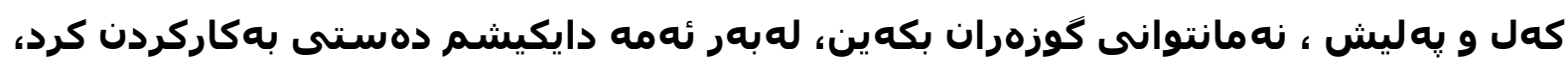

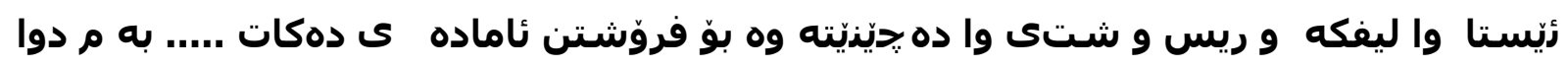

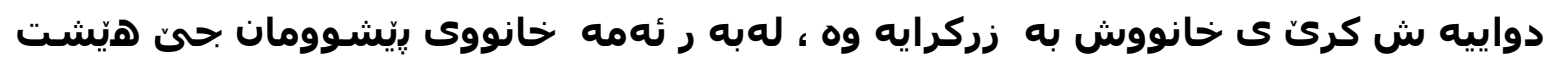

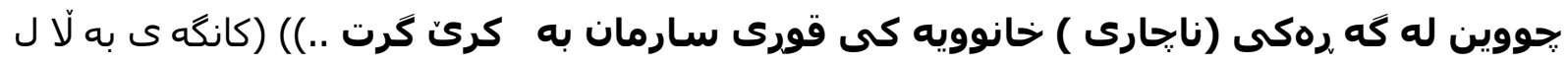

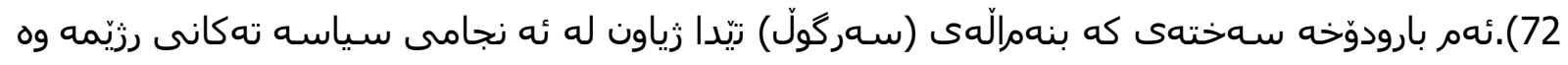

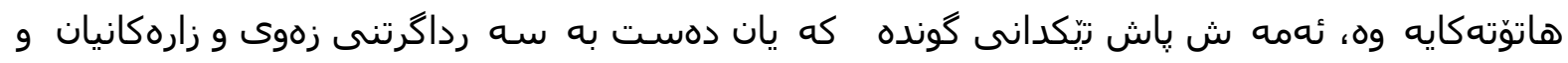

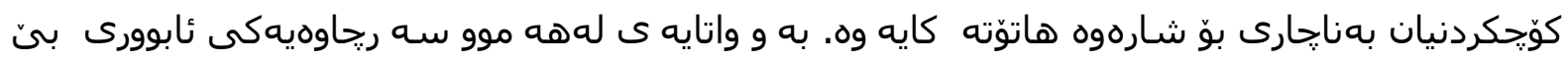

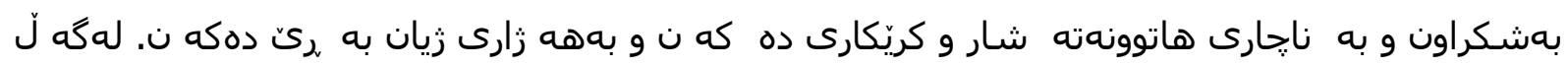

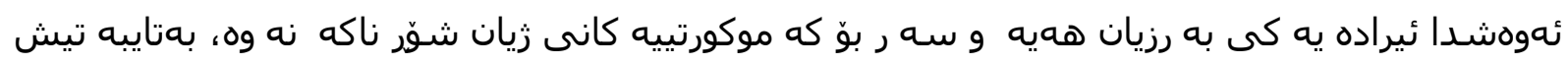

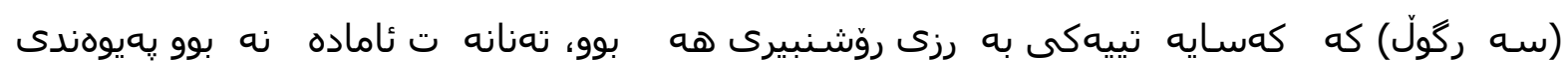

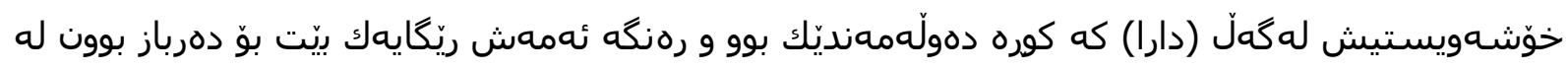

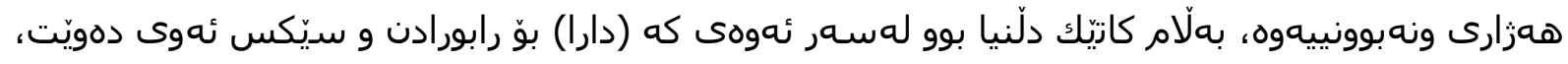

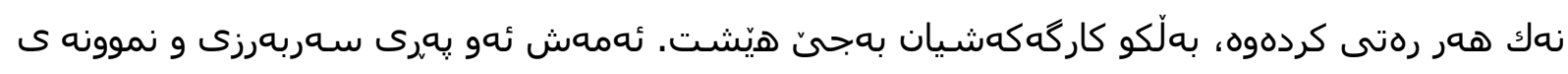

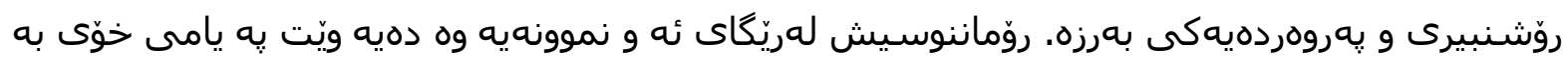

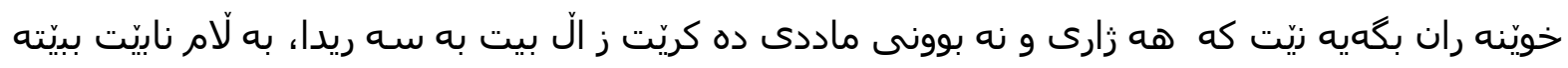

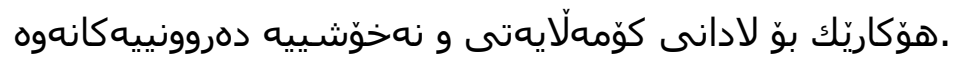

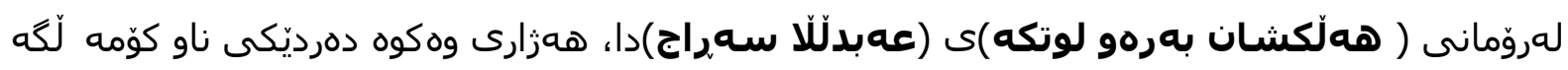

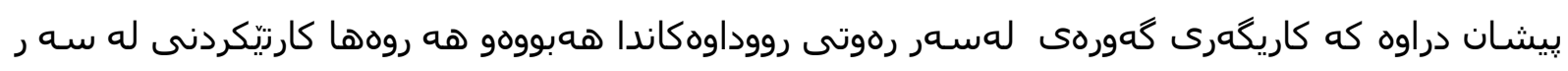

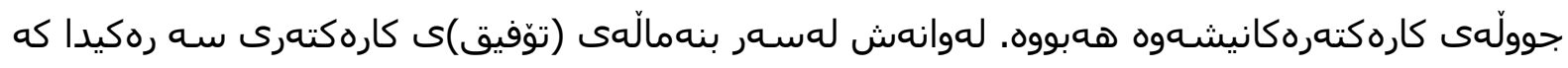

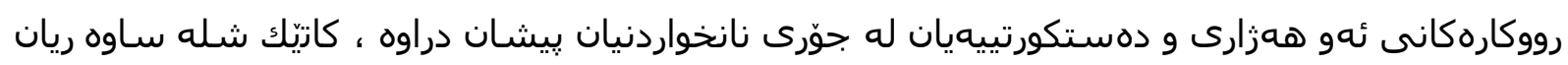

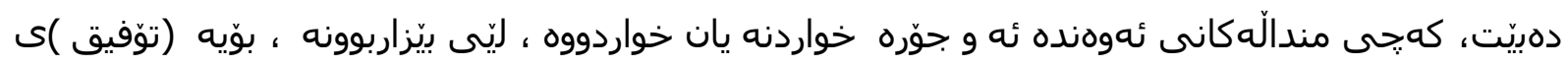

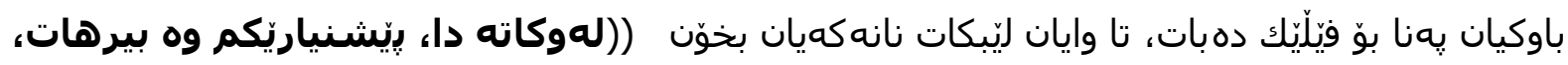

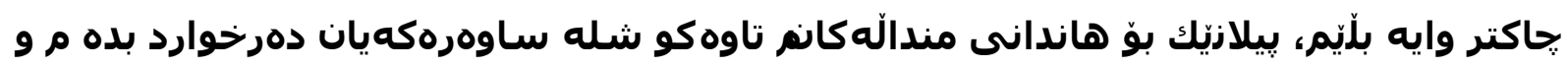

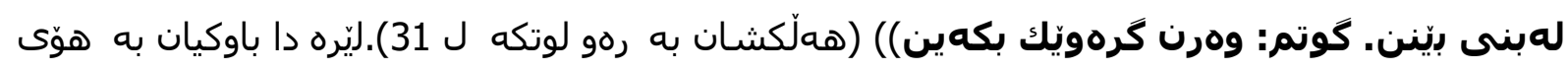

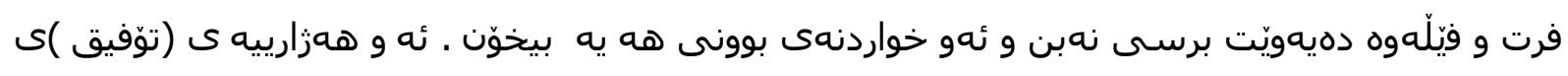

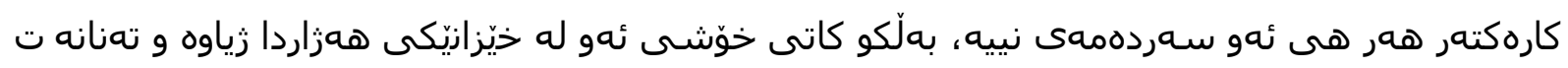

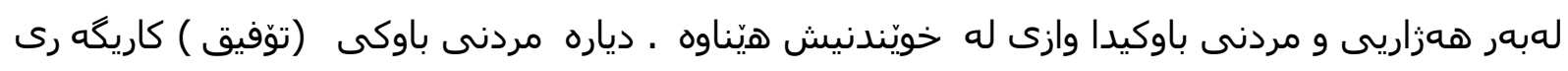

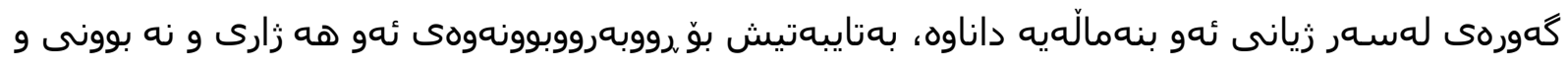

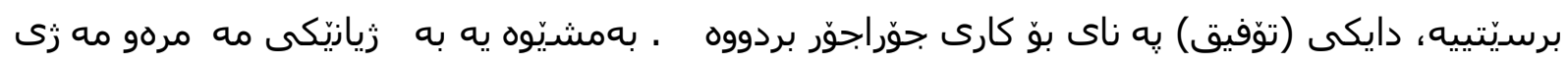

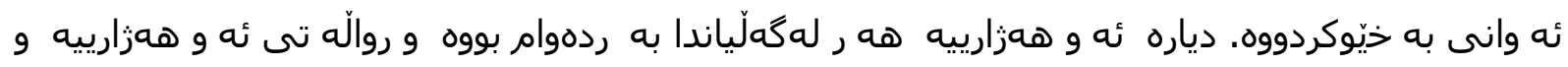

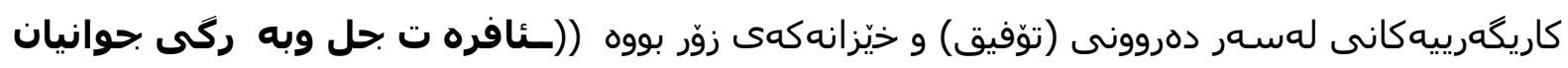

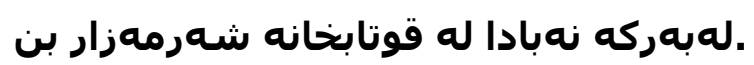

خاته بير قورگى كريان بوو، همستم بهوه كردو دلّنهواييم دايهوه. 
ـ شـكر له هيجيان كهم نى يه، (ههريحهنده كَوْشت كرانه، خوّ نهخواردنى ههرزانه).

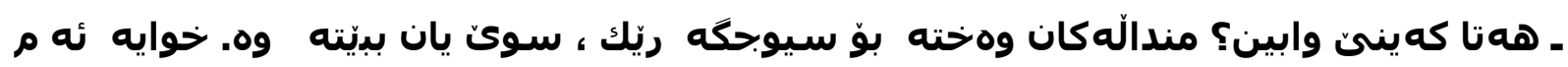

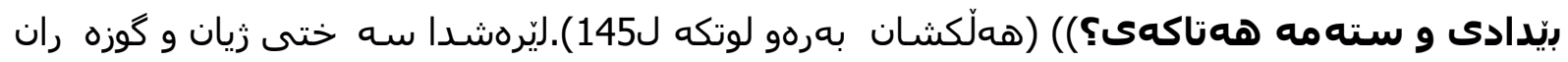

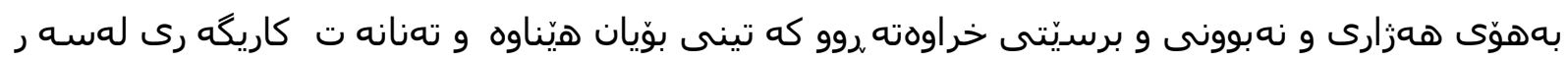

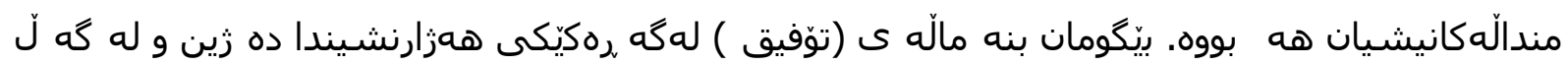

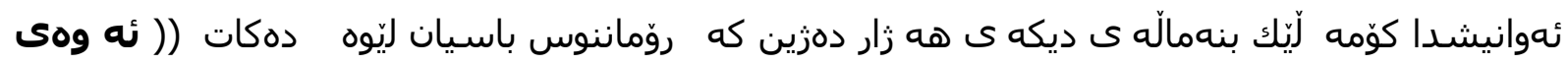

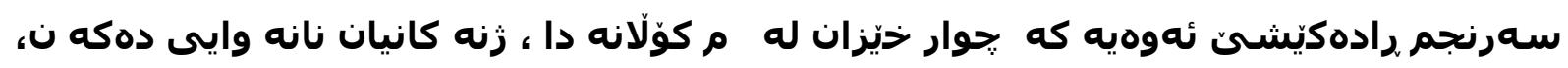

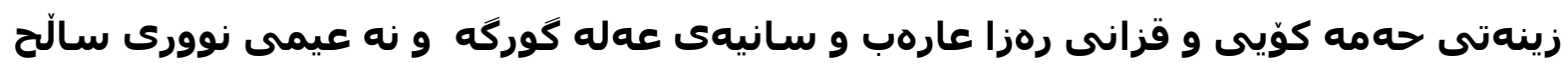

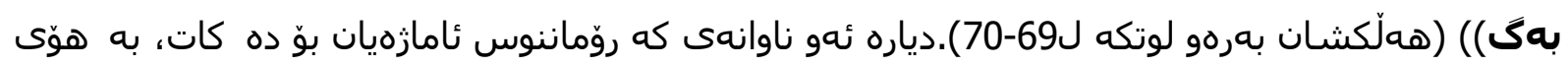

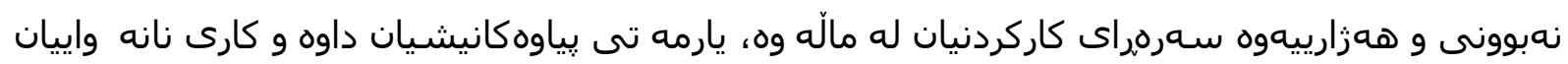

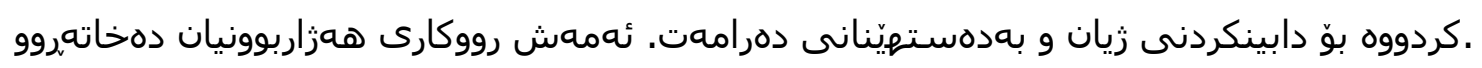

لهلايه كى ديكهشه وه روّم اننوس ئامازه ى به دياردهيه كى ديكه ى ناو كوّمه لْكَ داوه كه ئه ويش

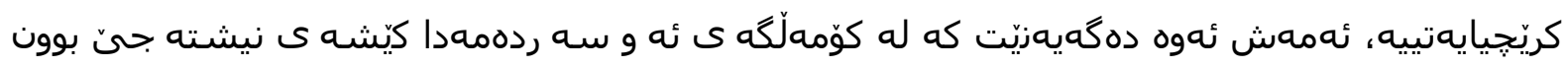

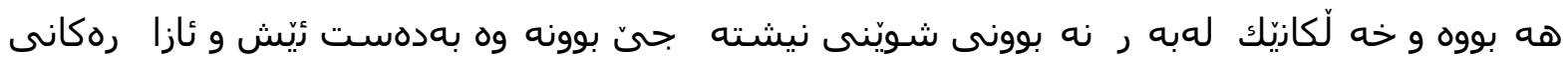

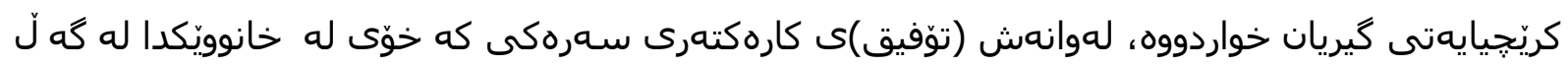

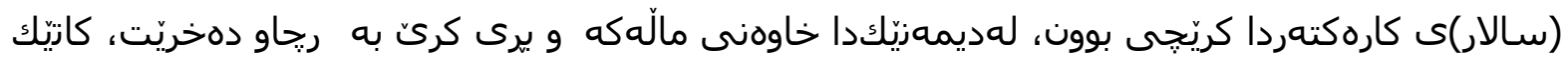

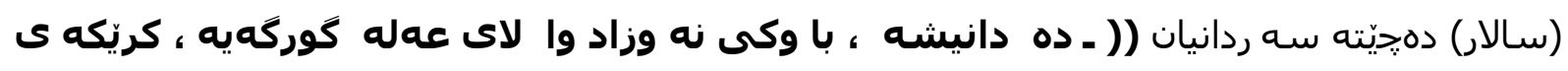

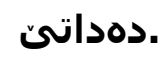

ـ بهراستى ، لهم كوّشك و ههيوانه، جحهندتان ليّوهردهكرى؟

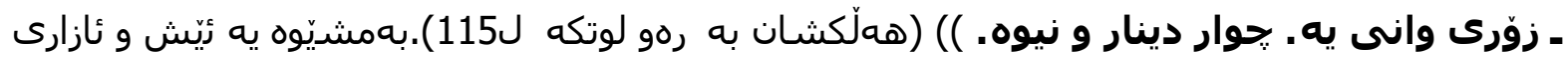

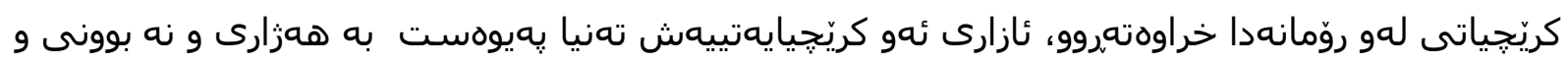

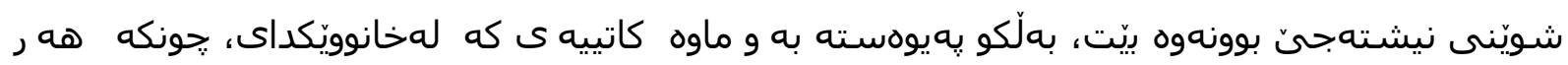

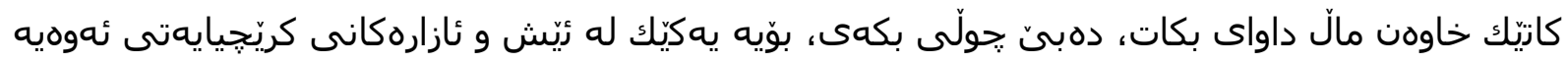

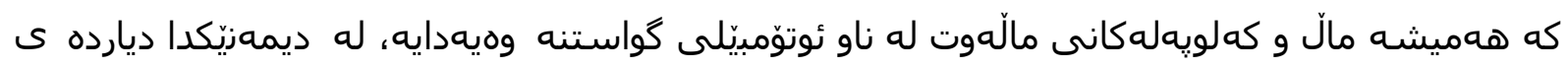

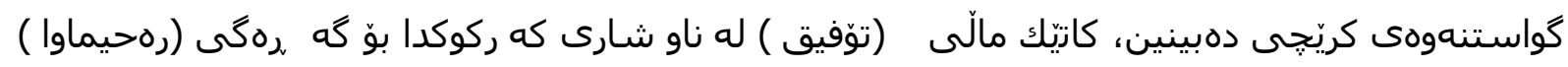

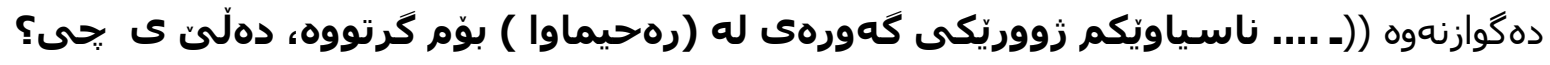

خاته: بِياوهكه، قسهقسـى خوّته. توّ جحوّنت بِن باش بِيت، زيّمه ئهوهمان دهوىن.

.. من: كهواته سبهى جومعهيه و دهكوازينهوه

إخاته: وا به يڤله

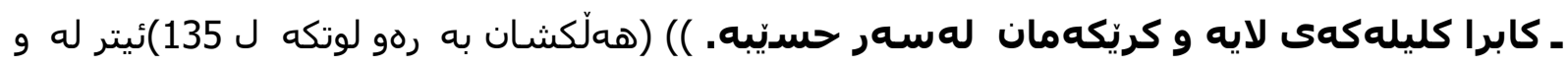

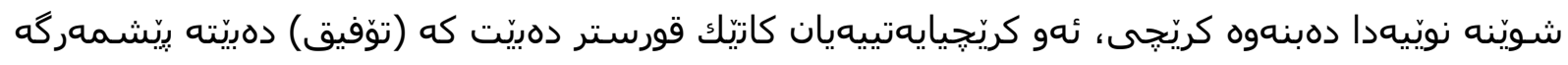

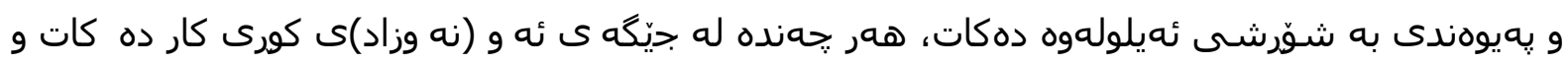




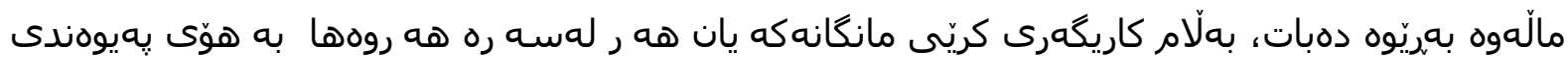

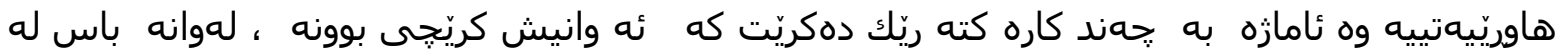

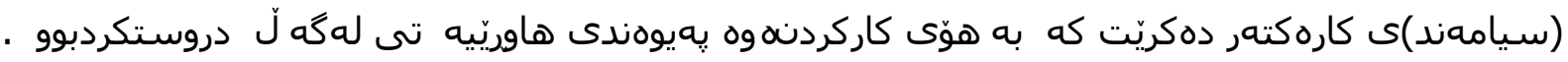

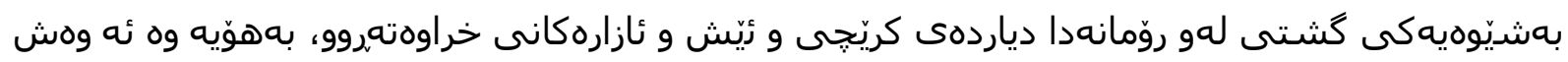

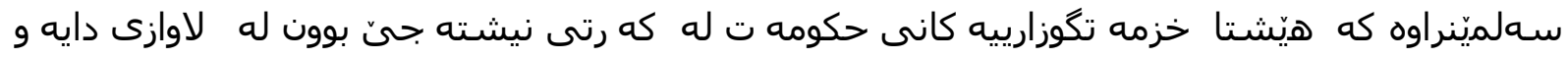

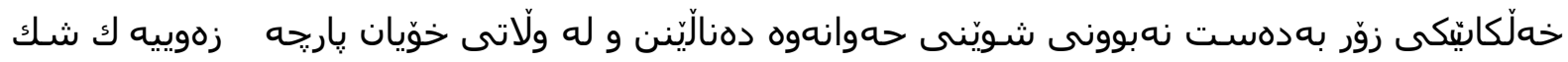

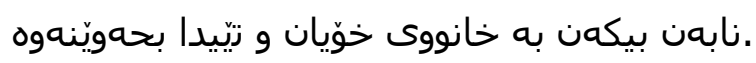

ئمنجامصكان

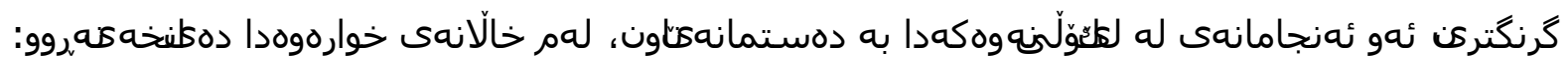

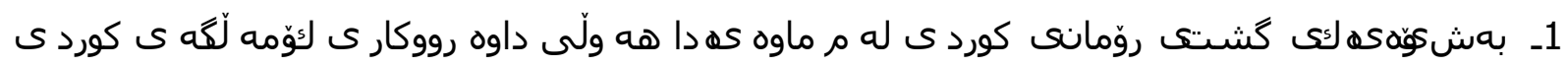

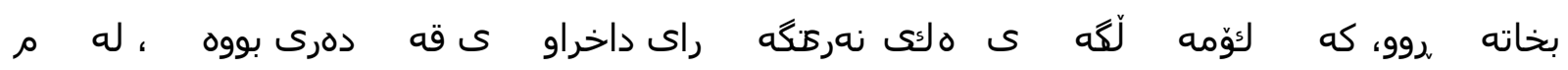

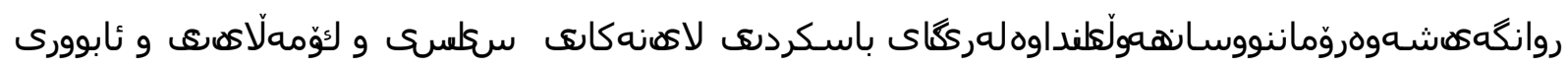

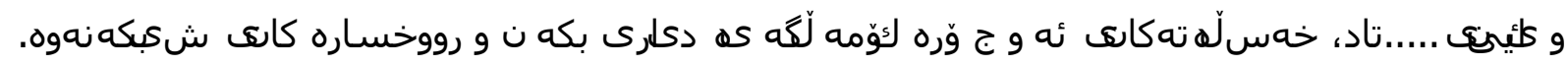




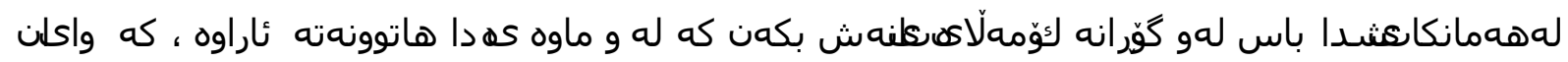

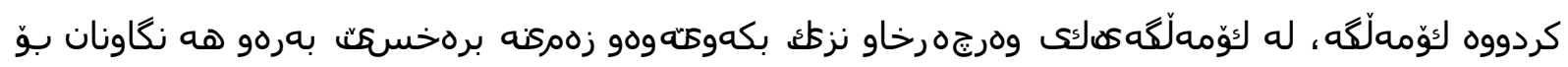

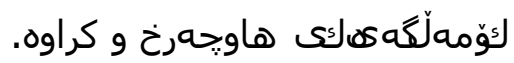

2ـ نهخوكّده وارى وهكو ده ردهو به لاكهك لهلاكهن روّماننوسانه وه ئاو رى لعكراوهته وه و كاركگه رى و

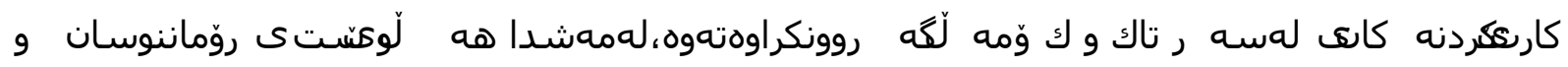

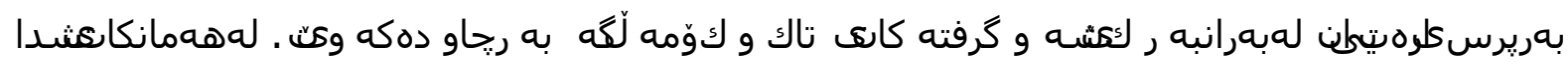

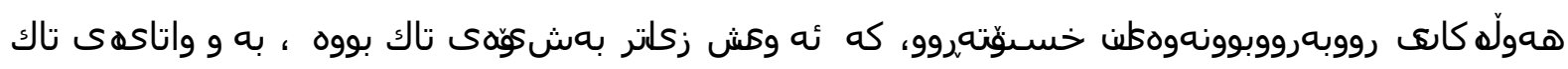

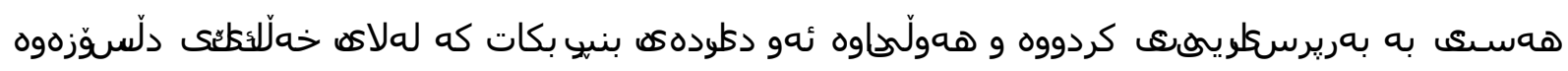

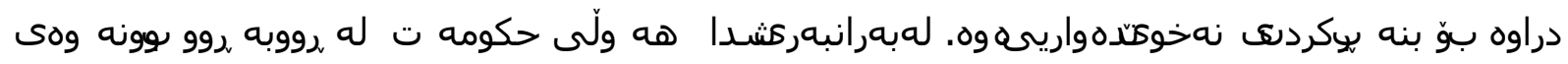

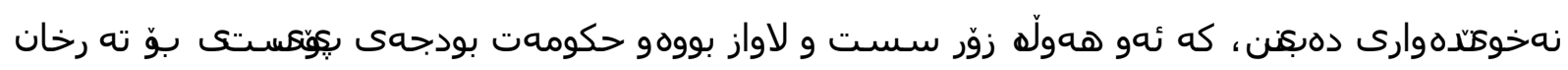

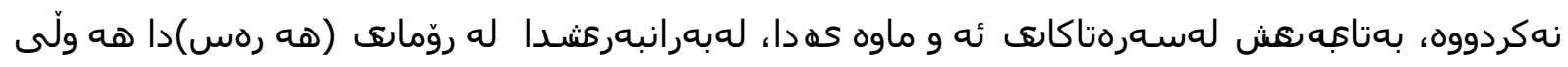

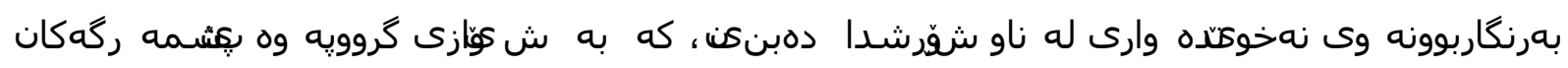

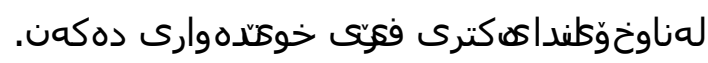

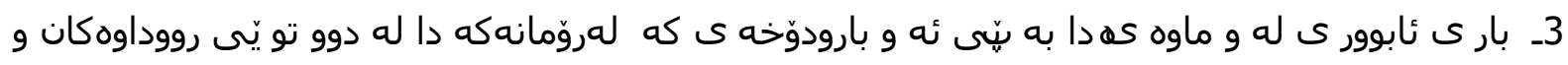

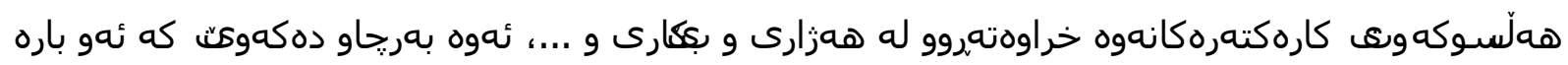

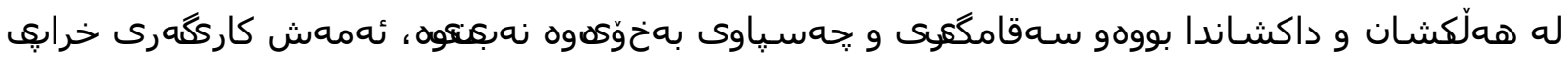

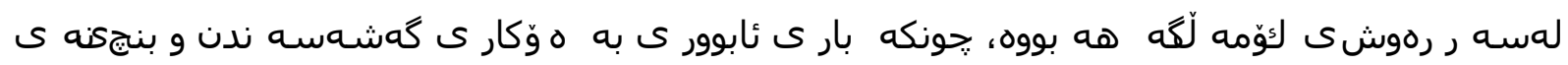

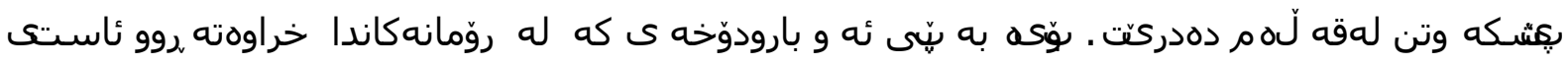

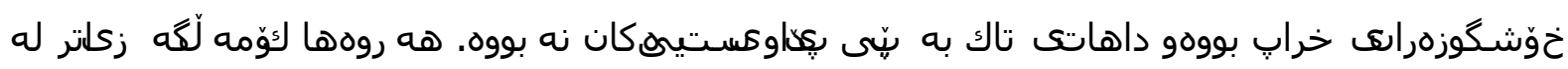

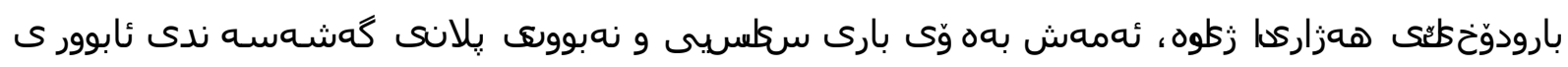

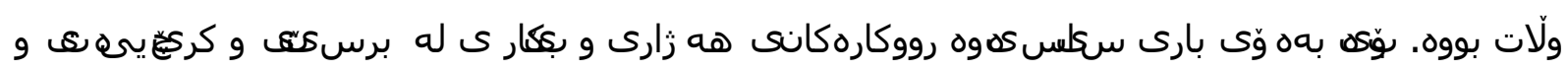
دهستكورع بهريحاو خراوه.

سaريجاوهكان

يهكمر: بهزمانى كوردى 
أـ كتيّب

1. د.ئيبراهيم حهسهن، رهنكدانهوهى كهله بوور له روّمانى كورديدا، يه كيتى نووسه رانى كورد ـ

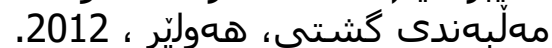

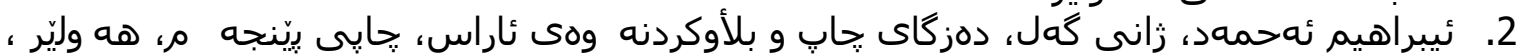

2010.

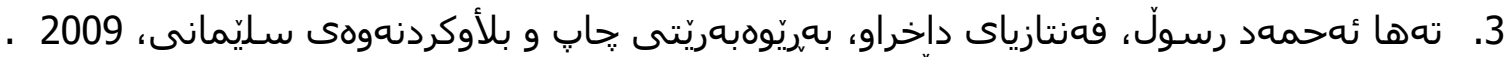

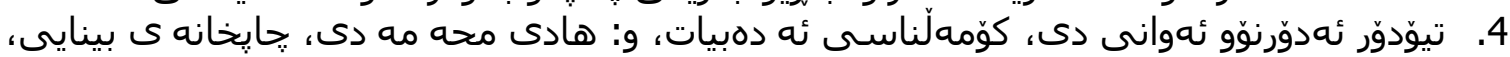

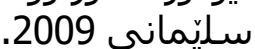

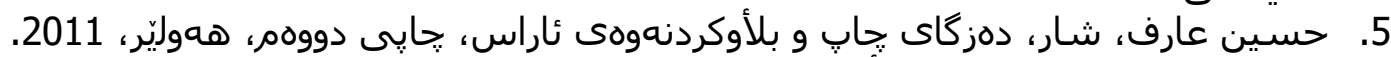

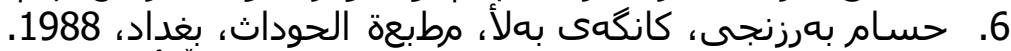
7. 8.

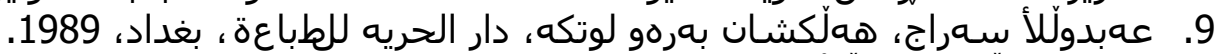

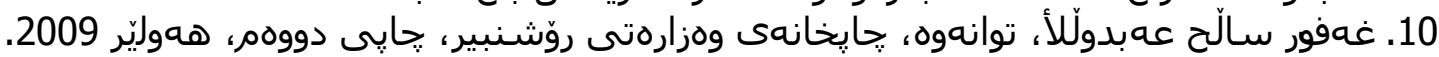

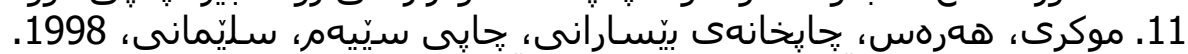

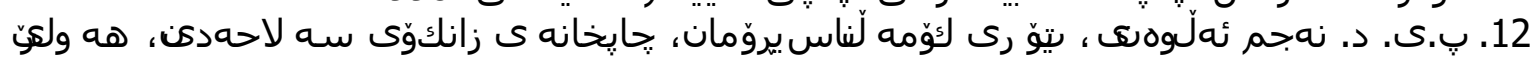
ب ـ بامaى ئهاديمى:

.2017

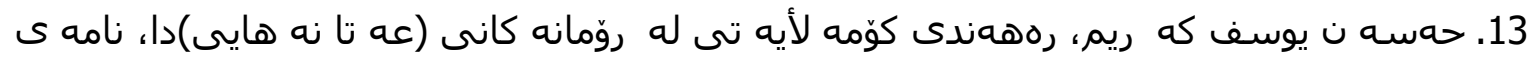

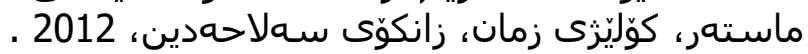

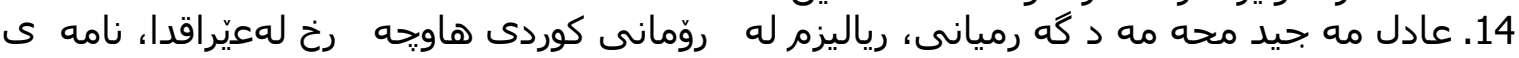

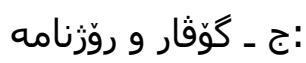

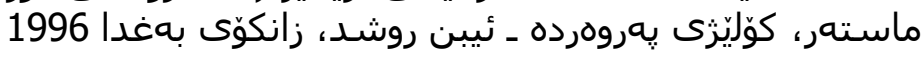

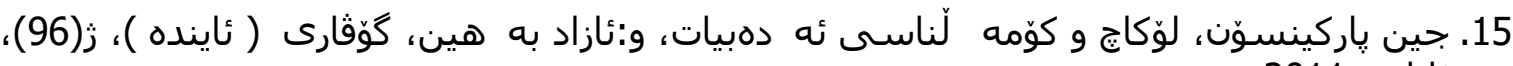
ئايارى

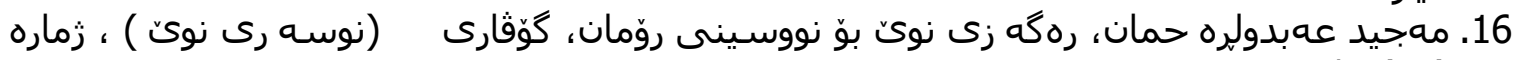
(45)،مايسى 2009.

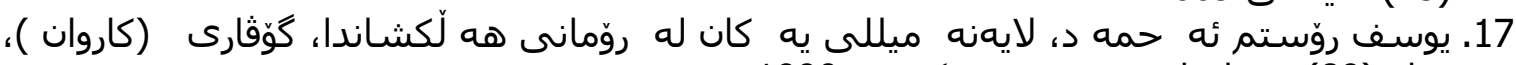

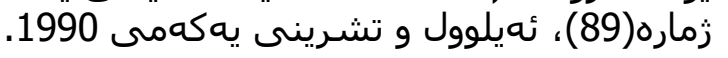

:دووهم: بهزمانى عaرهبى:

أـ كتيّب

18. بول أرون و الان فيالا، سوسيولوجيا الأدب، ت: د.مجد على مقلد، دار الكتاب الجديد ة المتحدة

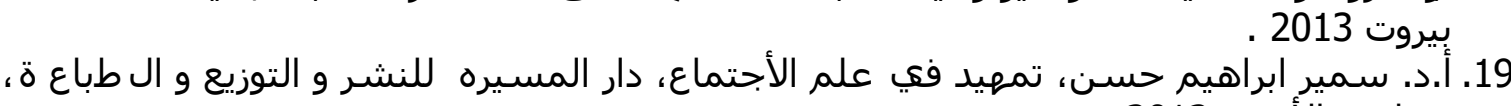

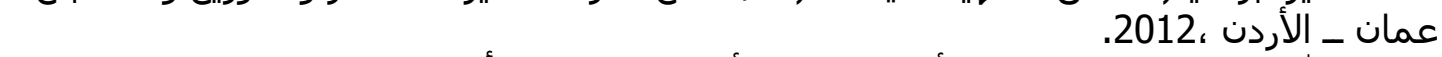

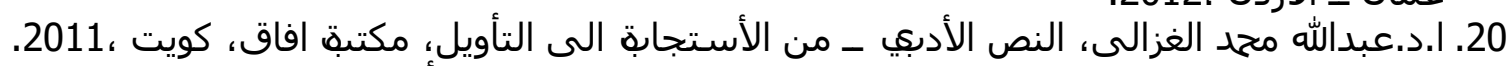

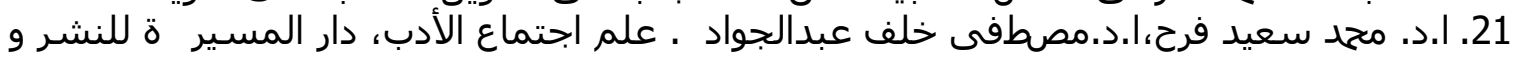
والتوزيع و الطباعة ، عمان، 2009.

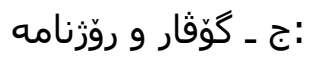

22. صبرى حافظ، الرواكة شكلا أدبيا و مؤسسة اجتماعنة، مجلة (الفصول )، المجلد (4)، العدد (1)،

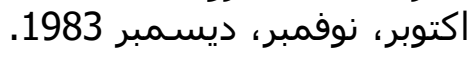


23. لوسيان غولدمان، البنوكة التكوية وتاريخ الأدب، ت:د.علي الشرع، مجله النقافة الأجنبقة، العدد

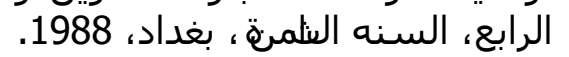
24. فايد مجحد، نظركة الرواءة لدى جورج لوكاش، مجلة (الرقيم)، العدد(5) ، الربيع 2014.

\section{REFERENCES}

\section{Books}

Abboud, H. (2010). In the history of the novel, translation, Abdulla Rahman, Manara Press, Arbil.

Abdalla, G. S. (2009). Solubility, Ministry of Culture Press, Second edition, Erbil.

Ahmed I. (2010). The labor of the people, Publishing \& Distribution Aras, 5th Edition, Arbil.

Aloni,N. (2017). Theory of sociology novel, University Press Salahaddin, Erbil.

Aref, H. (2011). The City, House of Printing and Distribution Aras, Second Edition, Erbil.

Barzanji, H. (1988). Source of the tragic, Al-Houdath Press, Baghdad.

Ederorno et al, T. (2009). Sociology sociology, translation: Hadi Mohamed, Binai Press, Sulaymaniyah.

Hassan, I., (2012). Reflection of Heritage in the Kurdish Novel, Kurdish Literary Union General Center, Erbil.

Malrach, A. S. (1986). General Secretariat of Culture and Youth, Erbil.

Rasoul, T. A. (2009). Fantasia closed, Directorate of print and distribution Sulaymaniyah,.

Siraj, A. (1989). Upgrade Towards the Summit, Dar Al-Huria for Printing, Baghdad.

Mukhery, (1998). Setback, Btassarani Printing Press, Third Edition, Sulaymaniyah.

\section{B -Academic Research}

Karim,Hassan Youssef,(2012).Social Dimensions in Novels (Atta Nuhayi), Master Thesis, Faculty of Languages, Salahuddin University,

Khermiani,Adel Majeed Mohammed, (1996).Realism in Contemporary Kurdish Novel in Iraq, Master Thesis, Faculty of Education Ibn Rushd, University of Baghdad.

\section{C - Newspapers and magazines}

Abdel Rahman, Majeed, (2009).The New Element in Novel Writing, Journal (New Writer), Issue (45), May.

Ahmed, Yusuf Rustam (1990).The Popular Cases in the Upgrade Novel, "Karwan," No. 89, September and October. 
Tharkinson,Jane, (2011). Lukas and Sociology Literature, Translated by: Azad Bahin, Journal (Future), Issue (96), May.

\section{Second: In Arabic}

\section{A- Books}

Arun, Paul \& Fiala, Alan, (2013).Sociology of Literature, translated by: Dr. Mohamed Ali Mekled, New United Book House, Beirut.

Farah, Mohamed Saeed, Abdel-Gawad, Mostafa El Khalaf, (2009). Sociology of Literature, Dar Al-Messayra for Publishing, Distribution and Printing, Amman.

Ghazali, Zabdallah Mohamed, (2011). Literary Text of Response to Interpretation, Afaq Library, Kuwait.

Hassan, Samir Ibrahim, (2012).Timed in Sociology, Dar Al-Mesireh for Publishing, Distribution and Printing, Amman Jordan.

\section{B - Newspapers and magazines}

Goldman, Lucian, (1988).The Structural Structure and the History of Literature, Translated by: Dr. Ali Shara, Journal of Foreign Culture, No. 4, 8th Year, Baghdad.

Hafez, Sabri, (1983).The Narrative of a Literary Form and a Social Institution,seasons Journal, vol. 4, No. 1, October, November, December

Mohammed, Fayed, (2014).The Theory of Novelism by George Lukasz, Al-Raqim Magazine, Issue (5), Spring 